\title{
QUALIDADE E DURABILIDADE DAS ESTRUTURAS DE CONCRETO ARMADO \\ - ASPECTOS RELATIVOS AO PROJETO -
}

\section{Ana Maria da Silva Brandão}

Dissertação apresentada à Escola de

Engenharia de São Carlos da

Universidade de São Paulo, como parte dos requisitos para obtenção do título de Mestre em Engenharia de Estruturas.

ORIENTADOR: Prof. Dr. Libânio Miranda Pinheiro 
Ficha catalográfica preparada pela Seção de Tratamento da Inform ação do Serviço de Biblioteca - EESC - USP

B817q

Brandão, Ana Maria da Silva

Qualidade e durabilidade das estruturas de concreto armado: aspectos relativos ao projeto / Ana Maria da Silva Brandão. -- São Carlos, 1998.

Dissertação (Mestrado) -- Escola de Engenharia de São Carlos-Universidade de São Paulo, 1998. Área: Engenharia de Estruturas. Orientador: Prof. Dr. Libânio Miranda Pinheiro.

1. Concreto armado. 2. Projeto. 3. Controle de qualidade. 4. Durabilidade. 5. Deterioração. I. Título. 
FOLHA DE APROVAC̄̃̃

Candidata: Engenheira ANA MARIA DA SILVA BRANDÃo

Dissertação defendida e aprovada em 16-04-1998

pela Comissão Julgadora:

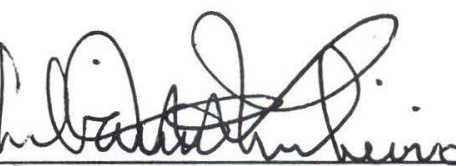

Prof. Doutor LIBÂNIO MIRANDA PINHEIRO (Orientador)

(Escola de Engenharia de São Carlos - Universidade de São Paulo)

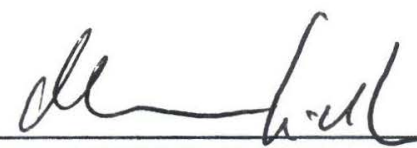

Prof. Associado MOUNIR KHALIL EE DEBS

(Escola de Engenharia de São Carlos - Universidade de São Paulo)

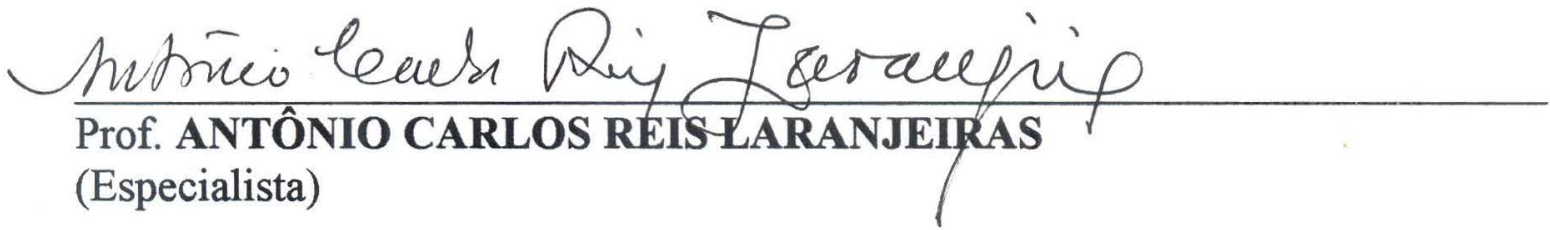

(Especialista)

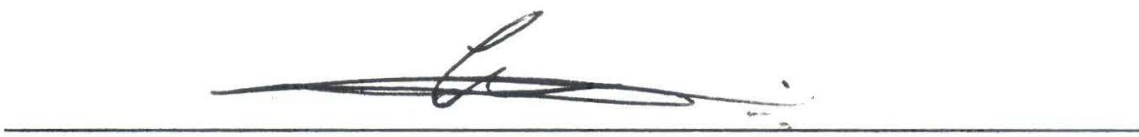

Prof. Titular CARLITO CALIL JUNIOR

Coordenador da Área de Engenharia de Estruturas

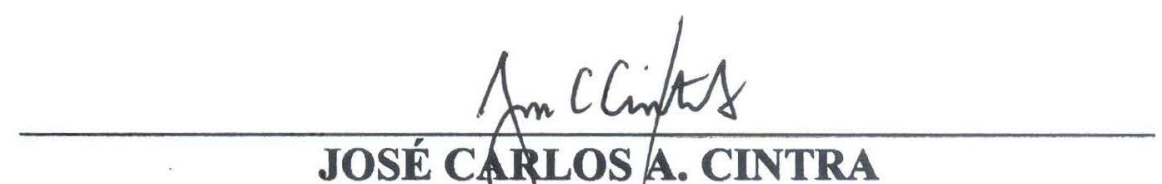

Presidente da Comissão de Pós-Graduação da EESC 
A o meu primo e marido, meu verdadeiro companheiro. 


\section{AGRADECIMENTOS}

A Deus, por ter me iluminado nesta longa jornada, possibilitando a concretização de mais uma etapa da minha vida profissional.

Ao Prof. Dr. Libânio Miranda Pinheiro, pela sua valiosa orientação ao longo de todo o desenvolvimento deste trabalho e, principalmente, por sua total confiança na minha capacidade.

Aos meus pais, pelo incentivo e apoio em todos os momentos durante o Curso de Mestrado e, em especial, ao meu marido, de quem a elaboração deste trabalho exigiu a renúncia de preciosos momentos de convivência e a quem este trabalho é dedicado.

Aos amigos, em especial Anamaria Miotto, Andréa Reis, Claudia Scoton, Rodrigo Soares e Eduardo Chaves, pela atenção e paciência com que me confortaram nos momentos mais difíceis.

Ao Prof. Antônio Carlos Reis Laranjeiras, pela gentileza de permitir a utilização de dados referentes a serviços executados em seu escritório de cálculo de estruturas, em Salvador, e pelo auxílio na pesquisa bibliográfica.

Aos professores do Departamento de Engenharia de Estruturas da Escola de Engenharia de São Carlos, que colaboraram com sugestões para o enriquecimento do trabalho.

Aos funcionários do Departamento de Engenharia de Estruturas da Escola de Engenharia de São Carlos, especialmente Maria Nadir Minatel e Rosi Aparecida Jordão Rodrigues, pela dedicação e eficiência nos serviços prestados.

À CAPES e à FAPESP, pelo apoio financeiro concedido.

A todos que, direta ou indiretamente, contribuíram para a realização deste trabalho. 


\section{SUMÁRIO}

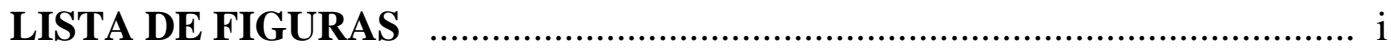

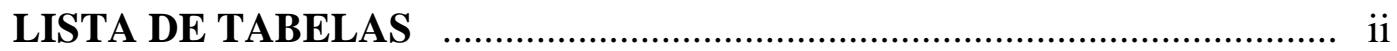

LISTA DE ABREVIATURAS E SIGLAS ....................................... iii

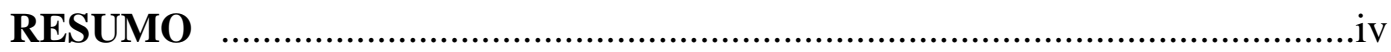

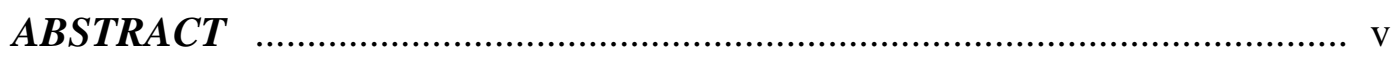

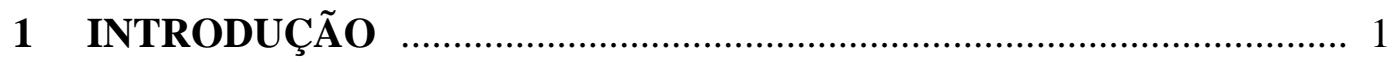

1.1 QUALIDADE ................................................................... 3

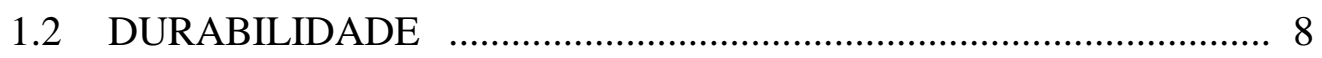

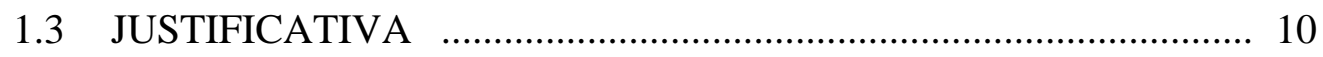

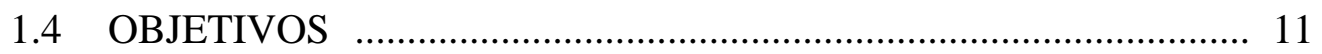

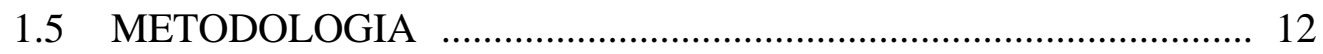

1.6 CONTEÚDO DO TRABALHO ................................................. 13

2 CONTROLE DA QUALIDADE DE PROJETOS ….......................... 14

2.1 DEFINIÇÕES ................................................................ 17

2.1.1 Qualidade ...................................................................... 18

2.1.2 Controle da Qualidade ....................................................... 19

2.1.3 Garantia da Qualidade ..................................................... 20

2.1.4 Não-Conformidade ....................................................... 22

2.1.5 Documentos de Referência …............................................ 22

2.1.6 Exigências da Qualidade .................................................... 23 
2.2 PRINCÍPIOS DO CONTROLE _............................................... 29

2.3 METODOLOGIA DO CONTROLE …....................................... 32

2.3.1 Identificação dos Documentos de Referência ........................ 33

2.3.2 Avaliação das Informações do Projeto ................................. 33

2.3.3 Classificação das Informações do Projeto ........................... 42

2.3.4 Realimentação do Projeto ................................................... 43

2.3.5 Elaboração de Relatório Conclusivo .................................... 44

3 DETERIORAÇÃO DO CONCRETO ….......................................... 46

3.1 MECANISMOS DE TRANSPORTE ........................................... 49

3.2 MECANISMOS DE DETERIORAÇÃO ..................................... 54

3.3 PROCESSOS QUÍMICOS ........................................................ 57

3.3.1 Ataque por Sulfatos ....................................................... 57

3.3.2 Ataque por Água do Mar ................................................. 59

3.3.3 Ataque por Ácidos ......................................................... 62

3.3.4 Ataque por Águas Puras ................................................... 65

3.3.5 Ataque por $\mathrm{CO}_{2}$ Agressivo _.......................................... 67

3.3.6 Reações com Agregados ................................................... 70

3.4 PROCESSOS FÍSICOS …..................................................... 72

3.4.1 Ciclo Gelo-Degelo ........................................................ 72

3.4.2 Cristalização de Sais ............................................................ 76

3.5 PROCESSOS MECÂNICOS …................................................ 77

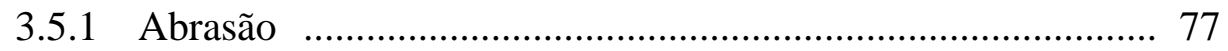

3.5.2 Cavitação .......................................................................... 79

3.6 PROCESSOS BIOLÓGICOS …................................................. 81

3.7 CORROSÃO DAS ARMADURAS …....................................... 82

3.7.1 Condições Essenciais para a Corrosão .................................. 83

3.7.2 O Processo da Corrosão e seus Efeitos .................................. 85

3.7.3 Principais Parâmetros Envolvidos e Recomendações .......... 86

3.8 AÇÃO DE ALTAS TEMPERATURAS ..................................... 88

4 CRITÉRIOS DE PROJETO PARA DURABILIDADE ….................. 92

4.1 PRINCÍPIOS E ESTRATÉGIA DO PROJETO ............................. 93

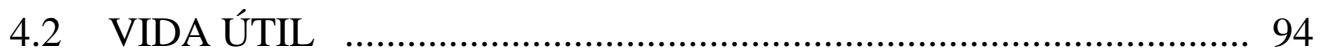


4.3 CONDIÇÕES AMBIENTAIS .................................................. 95

4.4 CRITÉRIOS DE PROJETO ….................................................. 98

4.4.1 Forma Estrutural _.......................................................... 98

4.4.2 Composição do Concreto ................................................... 100

4.4.3 Qualidade e Espessura do Cobrimento .............................. 102

4.4.4 Detalhamento das Armaduras ........................................... 103

4.4.5 Limitação da Abertura das Fissuras ................................... 104

4.4.6 Medidas Especiais de Proteção ........................................... 105

4.4.7 Planos de Inspeção e de Manutenção ................................ 105

4.5 ASPECTOS RELATIVOS À EXECUÇÃO ................................ 106

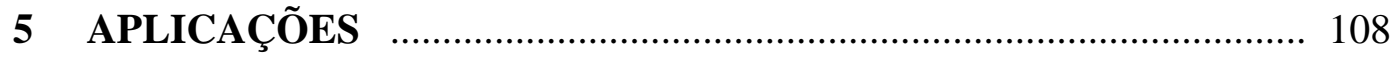

5.1 EDIFÍCIO RESIDENCIAL .................................................. 109

5.2 RESERVATÓRIO CILÍNDRICO .......................................... 119

6 CONSIDERAÇÕES FINAIS ….................................................. 129

REFERÊNCIAS BIBLIOGRÁFICAS _........................................... 132

BIBLIOGRAFIA COMPLEMENTAR _.............................................. 135 


\section{LISTA DE FIGURAS}

Figura 1.1 - Representação das etapas principais do processo construtivo.

Figura 3.1 - Desenvolvimento da deterioração com o tempo.

Figura 5.1 - Vista superior do edifício (desenho esquemático).

Figura 5.2 - Corte longitudinal do edifício (desenho esquemático).

Figura 5.3 - Locação dos pilares (desenho esquemático).

Figura 5.4 - Detalhe da planta de formas dos pisos de apartamentos (desenho esquemático).

Figura 5.5 - Corte vertical do reservatório cilíndrico apoiado (desenho esquemático).

Figura 5.6 - Alternativas de fundação para o pilar solidário com a laje do fundo.

Figura 5.7 - O chanfro no bordo da laje de fundação favorece a durabilidade.

Figura 5.8 - Sugestão para armaduras na ligação da parede com a laje de fundo.

Figura 5.9 - Prever a posição das juntas e seus respectivos mata-juntas.

Figura 5.10 - Alternativas de drenagem da tampa do reservatório.

Figura 5.11 - Alternativa de adotar um único pilar central. 


\section{LISTA DE TABELAS}

Tabela 2.1 - Lista de pontos e aspectos críticos comuns em projetos estruturais. (Ref. LARANJEIRAS, 1993 e CEB Bulletin d'Information n.157, 1983)

Tabela 2.2 - Exemplo 1 de lista de verificações, sob o formato de itens.

Tabela 2.3 - Exemplo 2 de lista de verificações, sob o formato de perguntas.

Tabela 4.1 - Classes de exposição referidas às condições ambientais. (CEB-FIP Model Code 1990, 1993)

Tabela 4.2 - Composição do concreto em função das classes de exposição.

Tabela 4.3 - Cobrimentos mínimos, em mm. (CEB-FIP Model Code 1990, 1993) 


\title{
LISTA DE ABREVIATURAS E SIGLAS
}

\author{
ABNT - Associação Brasileira de Normas Técnicas \\ ACI - American Concrete Institute \\ ANSI - American National Standards Institute \\ ASQC - American Society for Quality Control \\ CEB - Comité Euro-International du Béton \\ CEN - Comité Européen de Normalisation \\ CSA - Canadian Standard Association \\ FIP - Fédération Internationale de la Précontrainte \\ ISO - International Organization for Standardization \\ JCSS - Joint Committee on Structural Safety \\ NB - Norma Brasileira \\ NBR - Norma Brasileira Registrada
}




\section{RESUMO}

BRANDÃO, A.M.S. (1998). Qualidade e durabilidade das estruturas de concreto armado: aspectos relativos ao projeto. São Carlos. Dissertação (mestrado) Escola de Engenharia de São Carlos, Universidade de São Paulo.

Nos últimos anos, tem-se observado grande preocupação do meio técnico com relação ao desempenho insatisfatório das construções. Alguns diagnósticos feitos sobre a ineficiência dessas construções apontam, dentre outras causas, as deficiências de projeto, juntamente com a utilização de materiais inadequados.

Neste trabalho, abordam-se a qualidade e a durabilidade das estruturas de concreto armado, concentrando-se em aspectos de projeto. $\mathrm{O}$ enfoque principal consiste na garantia da qualidade das estruturas, a partir da melhoria da qualidade dos respectivos projetos estruturais. Esta melhoria pode ser conseguida, basicamente, de duas formas: através da implantação de um sistema de garantia da qualidade de projetos estruturais e mediante elaboração de especificações apropriadas de projeto.

Assim, são propostas algumas diretrizes para o controle da qualidade de projetos estruturais. Apresenta-se, também, um estudo sobre o comportamento do concreto armado face à agressividade ambiental, a partir do qual são discutidos diversos critérios de projeto, com vistas à durabilidade das estruturas, aspecto que está intimamente relacionado com a qualidade.

Por fim, apresentam-se algumas aplicações práticas dos conceitos e dos procedimentos abordados, com o objetivo primordial de demonstrar a aplicação da metodologia proposta para o controle da qualidade de projetos estruturais.

Palavras-chave: concreto armado, projeto, controle da qualidade, durabilidade, deterioração. 


\begin{abstract}
BRANDÃO, A.M.S. (1998). Quality and durability of reinforced concrete structures: design approach. São Carlos. Dissertação (mestrado) - Escola de Engenharia de São Carlos, Universidade de São Paulo.

In the last years, it has been observed a great concern about the unsatisfactory performance of the constructions. Some studies on the inefficiency of these constructions point, among other causes, to faulty designs, along with the use of inadequate materials.

This work draws the attention to quality and durability of reinforced concrete structures, concentrating on design aspects. The main approach consists of ensuring the structure quality by improving the respective structural design quality. This improvement can be achieved, basically, by two ways: through implementation of a quality assurance system for structural design and by means of appropriate design specifications.

Thus, this work gives guidance for the development of structural design quality control and also presents a study on the behavior of reinforced concrete subjected to aggressive environments. This study forms a basis for the presentation of some durability design criteria, which is largely related to the structure quality.

Finally, some practical applications of the concepts and procedures covered in the text are presented, aiming primarily at demonstrating the application of the methodology proposed for structural design quality control.
\end{abstract}

Keywords: reinforced concrete, design, quality control, durability, deterioration. 


\section{INTRODUÇÃO}

Segundo algumas estatísticas publicadas, grande parte dos defeitos verificados nas construções decorrem de erros de projeto. De fato, muitos diagnósticos sobre as causas do desperdício e da ineficiência das construções, tendo em vista sua funcionalidade e durabilidade, apontam para deficiências de projeto. É essencial, portanto, que sejam direcionados maiores esforços no sentido de melhorar a qualidade dos projetos, em especial, o projeto estrutural, dada a sua significativa importância, possibilitando corrigir eventuais falhas e, assim, reduzir os riscos de mau comportamento da estrutura em serviço.

Uma das formas encontradas para conseguir a melhoria da qualidade dos projetos estruturais é através da implantação de um sistema de garantia da qualidade, atuando paralelamente ao desenvolvimento dos projetos. Embora o controle da qualidade, associado ao desenvolvimento de um projeto bem elaborado, possa parecer dispendioso, é plenamente compensado pelos reflexos financeiros positivos proporcionados pela prevenção de defeitos e pela redução dos desperdícios e dos prazos, além de conduzir a uma solução construtiva melhor.

As empresas que contratam projetos, muitas vezes, partem do enfoque custo (preço), deixando a qualidade em segundo plano. Outras vezes, o fator condicionante é o prazo. O cumprimento do prazo acaba sendo o objetivo primordial e isso, certamente, afeta desfavoravelmente a eficiência das estruturas, pois impossibilita os projetistas de buscarem a melhor solução. Estes, por sua vez, premidos pelas circunstâncias do mercado, aceitam as condições impostas e acabam realizando o projeto concomitantemente com o desenvolvimento da obra, prejudicando a racionalização e, conseqüentemente, comprometendo a qualidade. 
Esta cultura em relação ao projeto precisa ser alterada no sentido de tentar se aproximar do que é feito nos países mais desenvolvidos: projetar em três meses e construir em um. Em outras palavras, deve ser dada ao projeto uma importância muito maior do que ele recebe hoje. Deve existir uma consciência de que vale investir mais em um bom projeto para gastar menos durante a execução da obra.

A busca pela racionalização na construção depende de um projeto bem elaborado. As falhas de projeto e o retrabalho custam infinitamente mais caro. Um projeto representa, em geral, 1 ou $2 \%$ do custo total da obra. Ao passo que uma solução bem desenvolvida gera uma economia de 15 a $20 \%$. Tal fato está se tornando cada vez mais evidente na visão de alguns órgãos governamentais e nas empresas privadas de ponta que têm melhor visão de futuro.

O trabalho a ser desenvolvido pretende ressaltar a influência do projeto sobre a qualidade das estruturas, salientando-se a necessidade da implantação de um sistema de garantia da qualidade que envolva todas as etapas do processo construtivo - planejamento, projeto, produção de materiais e componentes, execução, utilização e manutenção -, com ênfase à fase de projeto, dada a sua extrema importância.

Um projeto bem elaborado deve conferir segurança às estruturas e garantirlhes desempenho satisfatório em serviço, além de aparência aceitável. Assim, devem ser observadas as exigências com relação à capacidade resistente, bem como às condições em uso normal e, principalmente, às especificações referentes à durabilidade.

Tem-se observado que, em geral, os requisitos de segurança são satisfatoriamente atendidos, ao passo que as exigências de bom desempenho em serviço e durabilidade são, muitas vezes, deixadas em segundo plano.

Assim, pretende-se abordar aspectos relativos à durabilidade, questão que está intimamente relacionada à qualidade das estruturas, ressaltando-se a necessidade de adotar critérios apropriados ainda na fase de projeto, de modo a garantir, com grau apropriado de confiabilidade, que as estruturas apresentem desempenho satisfatório 
em serviço e resistam adequadamente aos agentes externos sem mostrar sinais precoces de deterioração.

Será dedicado um capítulo ao estudo do comportamento do concreto armado face à agressividade ambiental, enfocando os principais mecanismos de deterioração que podem conduzir à degradação das estruturas. Com este estudo, pretende-se justificar a adoção de determinados critérios de projeto, tais como espessura mínima de cobrimento, limites para abertura das fissuras etc., além de salientar a importância e a necessidade de empregar procedimentos adequados na produção do concreto quando da execução das estruturas, principalmente os aspectos relativos à cura, fator que, indiscutivelmente, exerce influência decisiva na qualidade do concreto produzido. $\mathrm{O}$ estudo da agressividade ambiental merece destaque, visto que afeta diretamente a durabilidade das estruturas.

Do exposto em linhas anteriores, percebe-se que há uma nítida relação entre os seguintes aspectos: agressividade ambiental, durabilidade e qualidade das estruturas. O estudo da agressividade ambiental visa conhecer o comportamento das estruturas e dos seus materiais componentes (concreto e aço) face aos ataques por agentes externos agressivos presentes no meio ambiente, de modo que possam ser tomadas as respectivas medidas preventivas de proteção, com o intuito de assegurar que as estruturas apresentem durabilidade. A garantia da durabilidade, por sua vez, contribui de forma considerável para garantir a qualidade das estruturas, visto que ambos os parâmetros estão, conforme mencionado anteriormente, intimamente relacionados.

Este trabalho pretende abordar detalhadamente os três aspectos mencionados, conforme será visto nos capítulos que seguem.

\subsection{QUALIDADE}

A qualidade de um produto pode ser considerada como a capacidade de atender a determinadas necessidades nas condições de uso previstas, devendo 
satisfazer a condições de segurança, higiene, conforto, funcionalidade, durabilidade e economia, dentre outras.

O controle da qualidade consiste, basicamente, num conjunto de técnicas operacionais e atividades desenvolvidas com o intuito de garantir que o produto final atenda aos requisitos da qualidade que lhe são impostos por especificações previamente estabelecidas.

A importância da qualidade se expressa pela adoção, por diversos países, das Normas Internacionais ISO (International Organization for Standardization) série 9000, que tratam dos requisitos mínimos para um sistema de garantia da qualidade. Tais normas incentivaram muitos países a criarem suas próprias normas de gerenciamento da qualidade, incluindo o Brasil que, recentemente, em 1994, publicou, através da Associação Brasileira de Normas Técnicas (ABNT), as normas série

NBR ISO. No Brasil, em particular, verifica-se maior preocupação com a qualidade a partir da aprovação do Código de Defesa do Consumidor, em vigor desde março de 1991.

A garantia da qualidade é um tema relativamente recente, tendo sido inicialmente desenvolvido para produção industrial. A evolução do controle da qualidade implantado na Indústria aconteceu em etapas sucessivas, conforme se descreve sucintamente nas linhas que seguem.

Até o final do século XIX, aproximadamente, o controle da qualidade era executado pelo próprio operário, responsável, tanto pelo projeto quanto pela fabricação do produto.

Com a revolução industrial, houve uma racionalização dos trabalhos, sendo designados grupos de operários, responsáveis por determinadas tarefas e supervisionados por um encarregado, que também se responsabilizava pelo controle da qualidade.

Após a $1^{\text {a }}$ Guerra Mundial, devido à maior complexidade dos processos produtivos, a supervisão da produção e o controle da qualidade passaram a 
representar funções distintas e exercidas por diferentes profissionais. Assim, surgiram os inspetores da qualidade, cuja função principal era avaliar a conformidade do produto com relação às especificações, detectando eventuais defeitos.

O período compreendido entre o final dos anos 30 e o fim da $2^{\mathrm{a}}$ Guerra Mundial caracterizou-se pelo aumento da produção e maior exigência, por parte dos consumidores, por produtos duráveis. Nessa época, as empresas passaram a realizar um controle da qualidade mais efetivo, recorrendo ao uso de gráficos de controle estatístico e inspeção por amostragem. Verifica-se, então, uma nítida separação entre as áreas de produção e de controle da qualidade.

A etapa seguinte da evolução do controle da qualidade caracterizou-se pelo surgimento do controle total da qualidade, atuando em todas as fases, desde o projeto até a produção, com grande ênfase à prevenção de defeitos, e não apenas à detecção.

Na Construção Civil, o processo pode ser simplificadamente representado pelo pentágono da Figura 1.1, onde se distinguem as seguintes etapas principais: planejamento, projeto, materiais, execução, uso e manutenção. Durante muito tempo, a atenção esteve totalmente voltada para as áreas de orçamento, projeto e produção, observando-se a ausência de preocupação com o controle da qualidade.

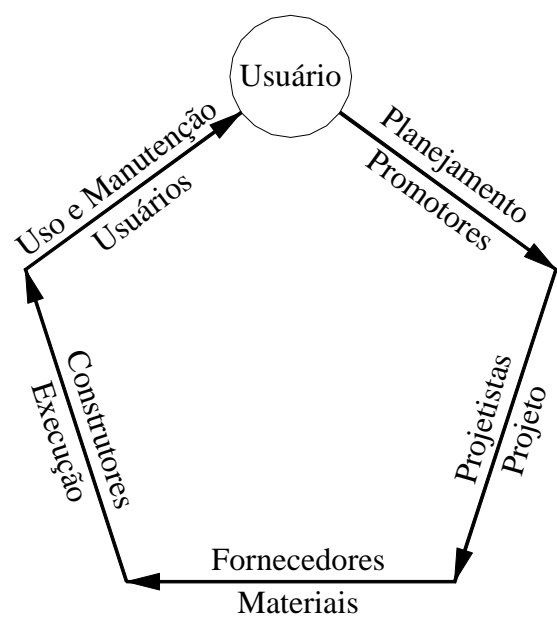

Figura 1.1 - Representação das etapas principais do processo construtivo. (Ref. CEB Bulletin d'Information n.157, 1983) 
Tradicionalmente, o controle da qualidade na Construção Civil identifica-se com a fiscalização de trabalhos e com a realização de alguns ensaios, atividades estas inseridas nas etapas de execução e materiais. Entretanto, a expressão controle da qualidade significa hoje algo muito mais complexo e elaborado, que engloba todo o processo construtivo, inclusive estabelecendo um compromisso entre todos os envolvidos - promotores, projetistas, fornecedores, construtores e usuários - na busca de um nível satisfatório de desempenho das construções.

A garantia da qualidade aplicada às atividades construtivas tem sido cada vez mais reconhecida como importante elemento de confiabilidade. Atualmente, as organizações com maior desenvolvimento tecnológico estão implantando Sistemas de Controle e de Garantia da Qualidade, como forma de alcançar maiores níveis de competitividade e, conseqüentemente, conquistar maior parcela do mercado. A preocupação com a qualidade é, de fato, uma característica típica de sociedades avançadas.

$\mathrm{Na}$ verdade, qualquer atividade, da qual resulta um produto final, empregando-se um determinado processo de fabricação, pode ser estatisticamente verificada, desde que o processo seja repetido sob as mesmas condições essenciais. Assim, não só produtos manufaturados, como também processos e serviços, podem ser checados com relação à sua qualidade.

O fato é que a indústria da construção apresenta características especiais que a tornam lenta, pouco ágil na aquisição e utilização das modernas técnicas de controle e de garantia da qualidade. Dentre essas características, pode-se notar:

- É uma indústria bastante tradicional e, portanto, dotada de grande inércia. De fato, o nível de conhecimento adquirido ao longo dos anos representa, no momento, o meio mais importante para alcançar confiabilidade nas construções.

- É afetada por códigos e regulamentações complexas, geralmente contraditórias e, às vezes, confusas. 
- No caso particular das construções de concreto, as dificuldades são maiores por ser este material bastante heterogêneo, cujas características variam com o tempo, principalmente nas primeiras idades.

Acrescente-se às características anteriormente mencionadas, o fato de que o setor construtivo emprega grande quantidade de mão-de-obra não especializada. Tem-se ressaltado que a indústria da construção pode ser considerada como uma esponja social necessária para absorver os trabalhadores que não correspondam aos padrões exigidos pelas indústrias mais sofisticadas. Se isto for verdade, dificilmente serão observadas mudanças significativas na qualidade das construções, sem que maior atenção seja voltada à melhoria da qualificação do pessoal empregado.

Pela Figura 1.1, observa-se que o processo construtivo começa no usuário, pois o principal objetivo do empreendimento é satisfazer as suas necessidades, e termina também no usuário, o qual será beneficiado com o produto final. As necessidades do usuário podem ser expressas por requisitos e critérios básicos, os quais, no caso das estruturas, estão relacionados à segurança, ao bom desempenho em serviço e à durabilidade. O objetivo da garantia da qualidade, portanto, é assegurar que os requisitos sejam atendidos de forma econômica.

As técnicas de controle da qualidade estão mais ou menos desenvolvidas, a depender da etapa do processo construtivo, sendo o maior desenvolvimento observado na fase de materiais, seguido de execução, projeto, planejamento, e manutenção, nesta ordem. Por outro lado, a origem de falhas nas construções encontra-se nas fases de projeto, execução e materiais, nesta ordem, a qual é a inversa do desenvolvimento das técnicas de controle da qualidade, anteriormente citada. Em outras palavras, os esforços referentes ao controle da qualidade são inversamente proporcionais à influência da etapa na qualidade final. Torna-se evidente, portanto, que maior atenção deve ser dada às etapas de planejamento e projeto.

O trabalho ora apresentado enfoca o controle da qualidade aplicado na fase de projeto, visto que este constitui uma peça fundamental, senão a mais importante no processo de aprimoramento da qualidade das construções. De fato, a qualidade do 
projeto é de extrema importância para a definição da qualidade do produto final, aqui representado pelas estruturas de concreto.

\subsection{DURABILIDADE}

Durante muito tempo, o concreto foi considerado um material extremamente durável, opinião esta baseada em obras muito antigas ainda em bom estado de conservação. Exames feitos recentemente, em 1987, na estrada de ferro Mairinque - Santos, em São Paulo, construída entre as décadas de 10 e 30, revelaram vigor invejável para uma obra relativamente antiga e com tão poucas recuperações sofridas ao longo dos anos.

Em contrapartida ao exemplo anteriormente citado, diagnósticos feitos em 1989 para a maioria das obras-de-arte da cidade de São Paulo, nascidas principalmente nos anos 70, apontam para surpreendentes problemas de durabilidade, considerando-se a pouca idade daquelas obras. A investigação realizada chegou a classificar como relativamente grave o estado de cerca de 100 obras.

A comparação entre esses diferentes comportamentos das estruturas ao longo dos anos remete aos porquês das patologias do concreto, responsáveis por sua deterioração e resultantes de uma somatória de fatores. Dentre estes fatores, citam-se: erros de projeto e de execução, inadequação dos materiais, má utilização da obra, agressividade do meio ambiente, falta de manutenção e ineficiência ou ausência de controle da qualidade na construção civil.

Crescem a preocupação com a durabilidade das estruturas de concreto e a busca pela resposta à indagação: Porque, após tantos anos de pesquisa, ainda existem tantos problemas referentes à durabilidade do concreto? Possivelmente, e os exemplos citados constatam este fato, existem mais problemas hoje do que havia 50 anos atrás. O tema é bastante abrangente e envolve inúmeros parâmetros, alguns dos quais serão discutidos no Capítulo 3. 
CARMONA FILHO apud SOUZA (1991), fundamentado em uma pesquisa realizada no final dos anos 80, aponta a execução como a principal causa das patologias do concreto, representando $52 \%$ dos casos, contra $18 \%$ do projeto, $24 \%$ da utilização inadequada e $6 \%$ dos materiais. A pesquisa de CARMONA FILHO foi inspirada no trabalho de MESEGUER apud SOUZA (1991) que, tomando por base diagnósticos de obras em diversos países europeus, detectou que $45 \%$ dos problemas se deviam a erros de projeto, $25 \%$ de execução, $10 \%$ a utilização inadequada e $20 \%$ a materiais. As discrepâncias entre os resultados das duas pesquisas se devem ao fato de que, na Europa, o controle da qualidade na execução está bastante avançado e, por isso, o projeto aparece como maior causador de patologias.

Observa-se que os erros de projeto, juntamente com a utilização de materiais inadequados, representam uma parcela relativamente grande das causas de patologias. Além disso, muitas falhas na execução poderiam ser evitadas se houvesse mais especificações no projeto, mesmo aquelas não previstas nas normas técnicas. Deve-se, portanto, providenciar para que o projeto seja elaborado de forma mais cuidadosa e detalhada, contendo especificações apropriadas e completas, principalmente com relação aos materiais a serem empregados.

Alguns autores acreditam que a principal causa da deterioração prematura das estruturas encontra-se na falta de qualidade da mão-de-obra e não na incapacidade do concreto de interagir com o ambiente ao qual é exposto. Segundo MATHER (1975) ${ }^{1}$ apud SKALNY (1987), quando uma estrutura ou um elemento de concreto apresenta desempenho insatisfatório, a razão repousa sobre uma das seguintes situações: (a) as especificações são deficientes, ou (b) as especificações são corretas, porém não são cumpridas.

Para que possam ser elaboradas especificações adequadas, torna-se imprescindível conhecer o comportamento dos materiais que compõem a estrutura quando submetidos a condições severas de exposição. Outro aspecto de extrema

\footnotetext{
${ }^{1}$ MATHER, B. (1975). Durability of concrete constructions - 50 years of progress. Journal of the Construction Division, ASCE, 101 (1975), p.5-14.
} 
relevância é a avaliação do nível de agressividade do meio ambiente. Tais aspectos serão oportunamente abordados neste trabalho.

Muitos autores, dentre eles MATHER (1987), acreditam que, hoje, o meio técnico já dispõe de conhecimento suficiente para projetar, especificar e construir estruturas duráveis de concreto. É possível produzir concretos resistentes às influências ambientais, apresentando degradação tolerável durante um determinado período de tempo, desde que sejam tomadas as devidas precauções, levando-se sempre em consideração a agressividade do meio ambiente. $\mathrm{O}$ desafio atual consiste, portanto, em garantir que o concreto não sofra deterioração excessiva ao longo do tempo, mediante especificações apropriadas, sem que, para isso, seja necessário aumentar os custos. O que falta, no momento, é a aceitação e a aplicação inteligente do conhecimento disponível e recentemente desenvolvido.

\subsection{JUSTIFICATIVA}

Indiscutivelmente, nos últimos anos, a questão da qualidade tem sido bastante evidenciada, tanto no Brasil como no exterior, seja devido à maior exigência por parte dos usuários ou à maior preocupação dos poderes públicos com relação à adequação ao uso e à durabilidade das estruturas, entre outros aspectos, seja pelo fato das empresas terem interesse em conquistar novos mercados.

O principal motivo para a elaboração deste trabalho encontra-se na ênfase, cada vez maior, que vem sendo dada à questão da qualidade na Construção Civil, em particular na área de projetos, aliada à escassez de referências bibliográficas sobre o controle da qualidade aplicado a projetos, os quais, conforme já mencionado, influem significativamente na qualidade das estruturas. De fato, são raras as publicações acessíveis a estudantes de Engenharia ou áreas afins e a profissionais que, por força das atividades que desenvolvem ou por interesse pelo assunto, necessitam de material para fins de formação, aperfeiçoamento ou simples informação.

A crescente preocupação com a qualidade das construções justifica a maior atenção dispensada às especificações de projeto que visem garantir não apenas a 
segurança com relação à capacidade resistente e de utilização, mas, principalmente, a durabilidade das estruturas, face aos agentes agressivos eventualmente presentes no ambiente em que se encontram.

Desta forma, desenvolveu-se o presente texto com o intuito de preencher uma lacuna que se julga existente e tornar disponível uma literatura que evidencie a importância, a necessidade e a conveniência de empreender esforços permanentes que conduzam à qualidade das estruturas.

\subsection{OBJETIVOS}

Face ao exposto, a elaboração deste trabalho tem como objetivos principais:

- Apresentar os conceitos de controle da qualidade, constantes nas normas mais recentes referentes ao assunto, para que possam ser aplicados à Construção Civil, com ênfase à área de projetos, suprindo, ainda que parcialmente, a necessidade de bibliografia mais específica sobre o assunto;

- Apresentar diretrizes para o controle da qualidade de projetos estruturais, de modo a garantir que a estrutura satisfaça às exigências da qualidade que lhe são impostas por especificações de normas, com vistas à segurança, funcionalidade, durabilidade, conforto, higiene e economia, dentre outros aspectos;

- Descrever o comportamento do concreto armado em ambientes agressivos, com grande concentração de sulfatos, cloretos, gás carbônico e outras substâncias, e em condições severas de exposição, identificando possíveis mecanismos de deterioração e recomendando medidas preventivas mínimas para combatê-los;

- Apresentar critérios de projeto para garantia da durabilidade das estruturas, de modo que elas apresentem comportamento adequado sob as condições 
previstas de uso, durante determinado tempo de sua existência, sem que sejam necessários altos custos para manutenção e recuperação.

\subsection{METODOLOGIA}

A metodologia aplicada no desenvolvimento deste trabalho consistiu, basicamente, de três etapas. Inicialmente, foi realizada uma ampla pesquisa bibliográfica, com o intuito de conhecer os trabalhos anteriormente publicados sobre controle da qualidade de projetos, influência da agressividade ambiental no comportamento do concreto armado e critérios de projeto para durabilidade das estruturas. Em seguida, fez-se uma análise de todo o material levantado e procederam-se as complementações necessárias, para, posteriormente, sintetizar, num documento único, as informações essenciais que pudessem servir de ferramenta na obtenção de níveis satisfatórios de qualidade dos projetos estruturais e, conseqüentemente, das estruturas de concreto armado. Por fim, fez-se uma exposição de como aplicar, na prática, os conceitos, procedimentos e critérios de projeto apresentados.

Para a efetivação dessas etapas de trabalho, tornou-se necessário o cumprimento das seguintes atividades:

- Investigação das normas mais recentes de garantia da qualidade, visando aplicá-las ao controle da qualidade de projetos estruturais;

- Apresentação de diretrizes para o controle da qualidade de projetos estruturais;

- Revisão da literatura existente sobre o comportamento do concreto armado em ambientes agressivos, com vistas à sua durabilidade;

- Apresentação de critérios de projeto para garantir a durabilidade das estruturas de concreto armado;

- Demonstração de aplicação prática;

- Considerações finais. 


\subsection{CONTEÚDO DO TRABALHO}

O texto que se segue compõe-se das seguintes partes:

- Capítulo 2 - Controle da Qualidade de Projetos. São fornecidas definições de alguns termos referentes à qualidade e apresentadas as diretrizes para o controle da qualidade de projetos estruturais. São discutidos, ainda, os princípios e os propósitos do controle e comentadas as atividades que devem ser efetuadas para verificar a qualidade dos projetos;

- Capítulo 3 - Deterioração do Concreto. Pretende-se, neste capítulo, descrever o comportamento do concreto armado, quando exposto a condições severas de exposição. Assim, são analisados o ataque por substâncias agressivas (tais como sulfatos, cloretos e gás carbônico, dentre outras), as ações mecânicas, a corrosão de armaduras e, também, situações de incêndios. A intenção é identificar os possíveis mecanismos de deterioração, de modo a possibilitar a adoção de medidas efetivas de prevenção e, conseqüentemente, garantir a durabilidade das estruturas;

- Capítulo 4 - Critérios de Projeto para Durabilidade. Neste capítulo, são abordados os princípios que devem reger o projeto com vistas à garantia da durabilidade das estruturas. Os conceitos de vida útil e condições ambientais são introduzidos e alguns critérios de projeto são apresentados e discutidos;

- Capítulo 5 - Aplicações. Constam deste capítulo duas aplicações práticas, com o objetivo de demonstrar o emprego dos conceitos de controle da qualidade de projetos e a verificação dos critérios de projeto para durabilidade;

- Capítulo 6 - Considerações Finais. Finalmente, apresentam-se as conclusões finais do trabalho, evidenciando os propósitos e as intenções que motivaram a sua elaboração. 


\section{CONTROLE DA QUALIDADE DE PROJETOS}

Na Construção Civil, as atividades de controle da qualidade, inicialmente direcionadas à execução propriamente dita da obra, apenas recentemente vêm sendo aplicadas à fase de projeto. Desde o advento do controle total da qualidade, ênfase cada vez maior tem sido dada ao projeto, visto que este exerce influência decisiva sobre a qualidade das construções. A qualidade do projeto é importante não só para atender às necessidades dos usuários, incluindo durabilidade e funcionalidade, mas também do ponto de vista da viabilidade de execução e do custo.

As estruturas de concreto devem apresentar um nível satisfatório de qualidade e se comportar adequadamente durante sua construção e por toda a vida útil especificada, resistindo a todas as ações e influências ambientais passíveis de ocorrer e a circunstâncias acidentais, sem apresentar danos desproporcionais às causas de origem. Neste sentido, o projeto estrutural tem a finalidade de conferir às estruturas esta capacidade de desempenhar apropriadamente suas funções, nas condições de uso previstas, de modo a evitar custos extraordinários e inesperados com sua manutenção e reparo.

Para assegurar a confiabilidade e a segurança das estruturas, deve-se manter um certo nível de garantia da qualidade em todas as etapas do processo construtivo, em especial, na fase de projeto. Assim, o projeto deve ser realizado por pessoal devidamente qualificado e deve ser submetido ao controle da qualidade, efetuado, de preferência, por pessoal independente e selecionado por sua competência e experiência.

Por sua importância, na verdade, a qualidade, muito antes de ser controlada, precisa ser produzida. Assim, uma medida para auxiliar a obtenção de projetos com qualidade assegurada consiste na definição de procedimentos específicos, tanto para 
a elaboração desses projetos quanto para a sua verificação, de modo a obter uma maior satisfação das necessidades dos usuários, reduzir a possibilidade de ocorrência de erros e otimizar o processo de execução.

O projeto deve, sempre que possível, ser feito de modo a facilitar as atividades de garantia da qualidade e outras atividades do processo construtivo. Assim, todas as informações utilizadas durante o projeto devem ser documentadas para fins de garantia da qualidade. Além disso, sempre que for previsto o emprego de processos construtivos especiais, devem ser elaboradas especificações detalhadas, descrevendo tais processos. Adicionalmente, devem ser elaborados, ainda na fase de projeto, planos de manutenção preventiva que ficarão, posteriormente, à disposição dos usuários. Portanto, durante o projeto, deve ser dada a devida atenção à viabilidade de executar o controle, bem como à viabilidade de execução, manutenção e reparo.

É importante salientar que, para a obtenção da garantia da qualidade, é fundamental que o desenvolvimento dos trabalhos seja realizado, principalmente, em função das caraterísticas de desempenho desejadas para a estrutura, e não só visando o atendimento das normas prescritivas, como acontece na maioria dos casos.

O controle da qualidade, assim como qualquer conceito, corre o risco de ser aplicado incorretamente. Seus princípios e técnicas são bastantes flexíveis. Em linhas gerais, o controle consiste nas seguintes etapas: coleta de informações, julgamento baseado nessas informações e decisão baseada no julgamento.

O Joint Committee on Structural Safety (JCSS) estudou a aplicação dos conceitos da garantia da qualidade à Construção Civil, tendo inclusive publicado, em 1981, um trabalho intitulado General principles on quality assurance for structures, contendo conceitos básicos, diretrizes gerais e um perfil das idéias fundamentais.

A nível internacional, o controle da qualidade tem sido objeto de estudo do Comité Euro-International du Béton (CEB) em diversas ocasiões. Como resultados destes estudos, destacam-se os bulletins d'information n.157 (1983) e n.184 (1988), importantes referências na elaboração do presente trabalho. 
O Bulletin d'Information n.157, publicado em 1983, consiste em aplicação e desenvolvimento dos princípios gerais da garantia da qualidade para as construções, enfocando as características peculiares da indústria da construção de concreto e a importância da consideração do fator humano. Este documento, de caráter parcialmente conceitual e parcialmente operacional, representa um passo intermediário entre princípios e recomendações e reflete o fato de que os conceitos da garantia da qualidade estão lentamente sendo incorporados ao setor da construção.

Por outro lado, o Bulletin d'Information n.184, publicado em 1988, é mais direcionado aos aspectos operacionais e à prática do gerenciamento da qualidade, sendo considerado, portanto, como um guia.

Apesar de sua importância na busca pela qualidade das construções, o controle da qualidade de projetos é uma atividade ainda pouco difundida no Brasil, onde começa a se desenvolver a exemplo do que ocorre na Europa e nos Estados Unidos.

Destaca-se, por exemplo, o trabalho de LARANJEIRAS (1993), responsável também por introduzir a filosofia do controle da qualidade de projetos na revisão da Norma Brasileira NB 1 (1994), tendo, inclusive, aplicado os conceitos e a metodologia do controle na verificação de diversos projetos estruturais. Conforme será visto oportunamente, grande parte deste capítulo baseia-se no citado trabalho e nos mencionados bulletins d'information do CEB.

A garantia da qualidade não pode ser completamente codificada. Os aspectos referentes ao comportamento humano são altamente subjetivos. Além disso, a intensidade com que ela é aplicada na prática depende, em grande parte, não só da magnitude e da complexidade do projeto, mas também da organização e da qualificação profissional nos diversos países.

A prática atual de verificação de projetos difere enormemente de país para país, devido a diferentes tradições e condições (legais, econômicas e técnicas) e, por esta razão, um método específico para controle de projetos não pode ser recomendado como válido para qualquer caso. 
Assim, abordam-se as medidas mínimas necessárias de controle da qualidade de projetos estruturais de concreto armado, incluindo ações e decisões essenciais, assim como verificações a serem feitas, de acordo com especificações e normas de cálculo, para assegurar que todos os requisitos especificados sejam atendidos.

Convém explicitar que não há intenção de apresentar regras rígidas, e sim diretrizes que forneçam alguns parâmetros para orientar a verificação de projetos. Assim, permite-se que cada profissional utilize tais parâmetros, adequando-os à sua situação particular. Deve-se esclarecer que o objetivo aqui pretendido é evocar idéias e não estabelecer regras.

\subsection{DEFINIÇÕES}

No campo da qualidade, muitos termos de uso corrente são empregados com significado específico ou mais restrito se comparado com as definições constantes dos dicionários.

Muitas vezes, os comitês responsáveis pela padronização desses termos, na busca de uma terminologia apropriada, encontram sérias dificuldades em estabelecer um acordo sobre termos comuns.

Em vista deste fato, dedica-se a primeira parte deste capítulo à apresentação das definições de alguns termos relativos à qualidade, tais como controle e garantia da qualidade, não-conformidade e documentos de referência. São discutidos os conceitos básicos e analisadas as principais exigências da qualidade para as estruturas e para os respectivos projetos estruturais. 


\subsubsection{Qualidade}

A palavra qualidade não chega a ser, em si, um termo técnico, sendo, na verdade, amplamente empregado na linguagem informal. Ela é usada na linguagem corrente, muitas vezes, com significados distintos para pessoas diferentes. É extremamente freqüente sua utilização em publicidade e atividades comerciais e de prestação de serviços em geral, o que levou à popularização do conceito de qualidade. Exatamente por essa razão, foram atribuídos diferentes significados ao termo, conforme o enfoque de quem dele faz uso.

De fato, qualidade tem muitas definições, visto que se aplica a uma ampla variedade de itens e tópicos. Essa variedade de conceitos sobre qualidade está presente também na literatura técnica sobre o assunto. Dentre as inúmeras definições encontradas, citam-se as seguintes:

Qualidade é a totalidade de características de um produto que lhe confere a capacidade de satisfazer determinadas necessidades (NBR ISO 8402, 1994).

Qualidade é a conformidade do produto com requisitos ou especificações previamente estabelecidos (CROSBY, $1979^{2}$ apud WADSWORTH, 1986).

Qualidade é adequação ou conveniência do produto ao uso pretendido (JURAN, 1980).

Qualidade é o nível em que um produto é apropriado para o uso especificado (SEGHEZZI, $1981^{3}$ apud SINHA, 1985).

Assim, a qualidade de uma construção será a capacidade que esta possui para atender às necessidades dos usuários nas condições de uso para as quais foi projetada. Pode-se considerar as necessidades atendidas, de modo geral, se forem satisfeitos os requisitos relativos à segurança, ao bom desempenho em serviço, à durabilidade, ao conforto visual, acústico, tátil e térmico, à higiene e à economia, dentre outros.

\footnotetext{
${ }^{2}$ CROSBY, P.B. (1979). Quality is free. New York, USA, McGraw-Hill.

${ }^{3}$ SEGHEZZI, H.D. (1981). What is quality: conformance with requirements or fitness for the intended use. EOQC Journal, 4, p.3.
} 
A qualidade do projeto estrutural, por sua vez, está vinculada à sua capacidade de traduzir as exigências dos usuários e os requisitos impostos pelas normas técnicas, conseqüentemente, permitindo que as estruturas preencham satisfatoriamente suas finalidades.

\subsubsection{Controle da Qualidade}

Assim como qualidade, o termo controle da qualidade tem também inúmeras definições. Genericamente, segundo JURAN (1980), o controle da qualidade pode ser entendido como o processo através do qual se pode medir o desempenho real de qualidade, compará-lo com um padrão previamente determinado e, se for o caso, agir no sentido de eliminar ou, pelo menos, amenizar as divergências observadas.

Muitas outras definições são usualmente empregadas, dentre as quais se destacam:

$\mathrm{O}$ controle da qualidade compreende as técnicas operacionais e atividades utilizadas para atender aos requisitos da qualidade, tanto para monitorar um processo, como para eliminar causas de desempenho insatisfatório, para atingir eficácia econômica (NBR ISO 8402, 1994).

O controle da qualidade consiste em técnicas operacionais e atividades que sustentam a qualidade de um produto que atende a determinadas necessidades (ANSI/ASQC Standard A3, $1978^{4}$ apud WADSWORTH, 1986).

O controle da qualidade é um conceito de extrema abrangência. Enquanto atividade, vai muito além de uma simples inspeção. Enquanto estrutura, é o sistema que cria condições para que as atividades preventivas possam ser desenvolvidas.

Com relação ao procedimento aplicado, podem-se distinguir dois tipos de controle que, apesar de distintos, normalmente, estão interligados. São eles:

\footnotetext{
${ }^{4}$ AMERICAN SOCIETY FOR QUALITY CONTROL (1978). ANSI/ASQC Standard A3 - Quality Systems Terminology. Wisc., Milwaukee.
} 
- Controle de produção, que é direcionado a um processo produtivo, com o propósito de conduzi-lo para garantir um resultado aceitável;

- Controle de conformidade, que é relacionado ao resultado de um processo produtivo, com o propósito de assegurar que o produto atenda às especificações dadas.

O controle de conformidade é realizado para verificar se um serviço específico ou produto foi executado em conformidade com as especificações previamente estabelecidas.

LARANJEIRAS (1993) afirma que "o Controle de Qualidade do Projeto integra-se à Garantia de Qualidade, e refere-se, genericamente, às técnicas operacionais e atividades empregadas para verificar e demonstrar o atendimento do mesmo às suas exigências de qualidade". Tais exigências são comentadas em detalhes no item 2.1.6.

\subsubsection{Garantia da Qualidade}

Um outro termo relativo à qualidade, mais abrangente do que o controle, é garantia da qualidade. Há muitos equívocos quanto à compreensão dos termos controle da qualidade e garantia da qualidade. A NBR ISO 8402 (1994) esclarece que, de modo simplificado, o controle da qualidade diz respeito aos meios operacionais utilizados para atender aos requisitos da qualidade, enquanto a garantia da qualidade visa prover confiança neste atendimento, tanto internamente, para a própria organização, como externamente, para o cliente. Em outras palavras, enquanto o controle da qualidade guarda preocupação de desenvolver atividades preventivas, a garantia da qualidade está voltada para a segurança que o consumidor deve ter ao utilizar o produto. Na verdade, a garantia da qualidade inclui o controle da qualidade.

Nas linhas que se seguem, são enunciadas algumas definições encontradas na literatura: 
A garantia da qualidade é o conjunto de todas as ações planejadas e sistemáticas, incluindo as atividades relacionadas ao controle da qualidade, necessárias para prover confiança adequada de que um produto atende aos requisitos definidos da qualidade e satisfaz determinadas necessidades (NBR ISO 8402, 1994).

Garantia da qualidade é um sistema de atividades, cujo propósito é assegurar que o controle total da qualidade está, de fato, sendo executado eficientemente (WADSWORTH, 1986).

Garantia da qualidade é uma configuração planejada e sistemática de todos os meios e ações projetados para prover adequada confiança de que o produto final cumpre com exigências contratuais e apresenta desempenho satisfatório em serviço (CSA, $1978{ }^{5}$ apud SINHA, 1985).

A garantia da qualidade pode ser definida como as atividades que, executadas de forma sistemática e planejada, visam assegurar a adequação à utilização que se deseja de um produto, dentro de níveis de desempenho, confiabilidade e custos aceitáveis (PALADINI, 1990).

A função da garantia da qualidade é assegurar que todas as atividades que interfiram na qualidade final de um produto sejam fundamentadas em requisitos básicos claramente definidos e que sejam corretamente executadas por pessoal competente e de acordo com planos previamente elaborados. Sua principal importância reside na possibilidade de proporcionar meios para atingir e manter a qualidade desejada. A garantia da qualidade não será completa, a menos que os requisitos definidos reflitam totalmente as expectativas dos usuários.

A garantia da qualidade compreende todas as medidas para atender a qualidade previamente definida, e, em particular, para evitar ou identificar erros. No caso da Construção Civil, em grande parte, ela consiste em estratégias contra erros humanos, uma vez que a experiência tem mostrado que essas são as principais causas de uma ruína estrutural.

\footnotetext{
${ }^{5}$ CANADIAN STANDARD ASSOCIATION (1978). Standard Z299.1-1978 - Quality Assurance Program Requirements.
} 
Objetivando a satisfação das necessidades dos usuários, a garantia da qualidade deve atuar desde a adequação do projeto às aplicações desejadas até a manutenção e utilização da estrutura. Tem caráter preventivo, no sentido de evitar que ocorram problemas ou que surjam novas situações de não-conformidade.

Aplicada ao projeto estrutural, a garantia da qualidade visa, através de ações planejadas e sistemáticas, garantir um nível de segurança de que ele satisfaz, de fato, às exigências da qualidade que lhe foram fixadas por condições arquitetônicas, construtivas, estruturais, funcionais e estéticas, dentre outras, e às exigências da qualidade referentes à segurança e à durabilidade, impostas pelas normas técnicas de projeto.

\subsubsection{Não-Conformidade}

A NBR ISO 8402 (1994) define não-conformidade como o não-atendimento de um requisito especificado. As condições de não-conformidade, segundo o ACI 121R (1985), são aquelas que podem afetar, desfavoravelmente, o desempenho satisfatório ou a aparência da estrutura, se permanecerem sem correção. Determinando-se a causa de tais condições, assim como as ações corretivas apropriadas, pode-se eliminar futuras e similares condições de não-conformidade e, inclusive, gastos desnecessários.

\subsubsection{Documentos de Referência}

Os documentos de referência, como o próprio termo indica, servem como referencial na análise comparativa das informações do projeto. Eles devem ser previamente identificados e classificados, segundo LARANJEIRAS (1993), em oficiais e não-oficiais.

Os documentos de referência oficiais são aqueles relativos à estrutura cujo projeto está sob controle da qualidade, constituindo-se, geralmente, de:

- Projeto arquitetônico; 
- Projetos dos outros sistemas: drenagem, elétrico, hidráulico, ar condicionado etc.;

- Relatórios e perfis de sondagem;

- Normas técnicas oficiais aplicáveis;

- Pareceres ou diretrizes técnicas escritas especificamente para a obra e que sejam hierarquicamente superiores ao projeto estrutural;

- Informações do mesmo projeto, constantes de desenhos já examinados e em vigor.

Os documentos de referência não-oficiais são todos os demais documentos que não se incluem no grupo anterior, como por exemplo, registros de práticas consagradas, recomendações e prescrições constantes da literatura técnica, mas não incorporadas, explicitamente, nas normas técnicas oficiais.

\subsubsection{Exigências da Qualidade}

As exigências da qualidade traduzem o conjunto de requisitos que devem ser atendidos por um determinado produto para que possa ser assegurada a sua qualidade. É essencial que esses requisitos reflitam completamente as necessidades e as expectativas do cliente.

A revisão da Norma Brasileira NB 1 (1994) apresenta dois capítulos que tratam das exigências da qualidade para estruturas de concreto e para os respectivos projetos estruturais. Grande parte do texto que segue é composta de transcrições desse documento, complementadas por informações constantes de outras referências.

\section{A. Exigências da Qualidade para as Estruturas}

As exigências da qualidade para uma estrutura de concreto podem ser classificadas em três grupos distintos, referentes, respectivamente, à segurança, ao bom desempenho em serviço e à durabilidade. Os requisitos relativos à segurança e ao bom desempenho em serviço devem ser observados durante toda a vida útil prevista para as estruturas, o que significa que elas devem ser projetadas e mantidas de modo que apresentem durabilidade adequada. As medidas a serem tomadas para 
garantir a segurança, o bom desempenho em serviço e a durabilidade de uma estrutura são baseadas nas condições de utilização e ambientais.

Grupo 1: Exigências relativas à capacidade resistente da estrutura ou de seus elementos componentes

A segurança de uma estrutura é a probabilidade de que a sua resistência seja maior do que os esforços a que é submetida, sendo a resistência medida pela sua capacidade de suportar ações e outras influências possíveis de ocorrer durante a construção e o uso, mantendo suficiente integridade estrutural durante e após acidentes. As exigências deste grupo correspondem à segurança à ruptura e deixam de ser satisfeitas quando são ultrapassados os respectivos estados limites últimos.

Os requisitos para segurança implicam em baixa (e aceitável) probabilidade de ruína estrutural capaz de causar danos à propriedade e perda de vidas humanas. $\mathrm{Na}$ avaliação do nível de segurança estrutural, devem ser feitas as devidas considerações de todas as circunstâncias que possam conduzir à ruína. Tais circunstâncias podem estar associadas a:

- uma combinação desfavorável de variáveis aleatórias (tais como ações, resistências, dimensões e outras);

- erros grosseiros;

- eventos excepcionais;

- falta de manutenção etc.

Assim, com vistas à garantia da segurança de uma estrutura, devem ser considerados todos os possíveis riscos, os quais podem ocorrer, por exemplo, como resultado de:

- valores de ações ultrapassados;

- valores de resistência de materiais mais baixos do que os especificados;

- valores de parâmetros geométricos diferentes dos especificados;

- efeitos nocivos de condições ambientais excepcionalmente desfavoráveis sobre a resistência da estrutura; 
- projeto, construção ou uso fora de controle como conseqüência de um erro grosseiro ou um evento excepcional.

Portanto, uma análise minuciosa dos riscos que podem ocorrer durante a fase de uso de uma estrutura forma a base para a especificação de medidas adequadas de segurança.

Grupo 2: Exigências relativas ao bom desempenho em serviço ou durante a construção

O bom desempenho em serviço de uma estrutura é representado pela sua capacidade de se comportar adequadamente quando submetida às condições de uso previstas. As exigências deste grupo referem-se a danos localizados, tais como fissuração excessiva, tensões exageradas de compressão, deformações inconvenientes e vibrações indesejáveis e deixam de ser atendidas quando os respectivos estados limites de utilização são ultrapassados.

Os requisitos para bom desempenho em serviço implicam em baixa (e aceitável) probabilidade de que a estrutura se torne imprópria para o uso. Portanto, tais requisitos referem-se a restrições contra:

- deformações que afetem o uso eficiente da estrutura ou a aparência de elementos estruturais e não estruturais;

- vibrações excessivas que produzam desconforto ou afetem elementos não estruturais ou equipamentos (principalmente, quando ocorre ressonância);

- danos localizados (incluindo fissuração) que reduzam a durabilidade da estrutura ou afetem a eficiência ou a aparência de elementos estruturais e não estruturais;

- outros efeitos especiais.

Assim, tendo em vista a garantia do bom desempenho em serviço (e, também, da durabilidade) de uma estrutura, devem ser consideradas todas as condições de utilização relevantes, as quais podem resultar, por exemplo, em:

- ações durante a fase em serviço e durante a fase de construção; 
- condições climáticas (vento, água, neve, gelo, temperatura e combinações desses elementos);

- influências tectônicas e geotécnicas (incluindo a interferência de construções vizinhas);

- efeitos da presença de água no solo.

Grupo 3: Exigências relativas à durabilidade das estruturas

Essas exigências têm como referência a conservação da estrutura, sem necessidade de reparos e manutenção dispendiosa, e deixam de ser cumpridas quando não são observados critérios de projeto que visem garantir a durabilidade das estruturas, protegendo-as contra deterioração prematura. Alguns desses critérios são propostos e comentados detalhadamente no Capítulo 4.

Além das exigências anteriormente mencionadas, podem ser fixados requisitos particulares para tipos especiais de estruturas (como, por exemplo, exigência de estanqueidade em reservatórios) e requisitos suplementares referentes a impacto ambiental e a aspectos estéticos e econômicos, por exemplo (Revisão da NB 1, 1994).

\section{B. Exigências da Qualidade para Projetos Estruturais}

Já se comentou anteriormente sobre a influência que a qualidade de um projeto exerce sobre a qualidade do produto final. Assim, para que as exigências da qualidade para as estruturas sejam devidamente satisfeitas, torna-se fundamental que algumas exigências da qualidade para os respectivos projetos estruturais também sejam atendidas. No julgamento da qualidade de um projeto, segundo o CEB Bulletin d'Information n.184 (1988), dois aspectos distintos devem ser claramente observados: a qualidade da solução adotada e a qualidade da descrição desta solução. 
A qualidade da solução adotada

LARANJEIRAS (1993) classifica as exigências da qualidade para a solução estrutural adotada nos seguintes tipos:

a) "Exigências de qualidade impostas pelas condições arquitetônicas, funcionais, construtivas, estruturais, de integração com os demais projetos (elétrico, hidráulico, ar condicionado, etc.) e econômicas.

As condições arquitetônicas impostas ao projeto estrutural são obviamente as constantes do projeto arquitetônico. No caso de inexistir o projeto arquitetônico - como é geralmente o caso das pontes, por exemplo - estas condições referem-se àquelas que devam reger tais projetos, como condições estéticas, de implantação, de drenagem, de impermeabilização e outras que forem igualmente aplicáveis.

As condições funcionais referem-se às finalidades e ao uso previsto para a estrutura, e implicam na compatibilização das ações a adotar, dos vãos e gabaritos, da rigidez e da deformabilidade das peças, da estanqueidade, das juntas de movimento, etc.

As condições construtivas implicam na compatibilização do projeto estrutural com os métodos, procedimentos e etapas construtivas previstas.

As condições estruturais referem-se basicamente à adequação das soluções estruturais adotadas, caracterizada pela escolha apropriada dos materiais concreto armado, concreto protendido, aço, pré-moldados, características dos próprios materiais; pelo sistema estrutural escolhido para resistir às ações verticais e às ações horizontais; pelo tipo de fundação; pela estrutura de piso - laje com ou sem vigas, nervuradas pré-fabricadas; pela definição de apoios, articulações, ligações entre elementos estruturais, etc.

As condições de integração com os demais projetos (elétrico, hidráulico, ar condicionado, etc.) referem-se às necessidades de prever rebaixos, furos, 
shafts ou dispor as peças estruturais de modo a viabilizar e compatibilizar a coexistência da estrutura com os demais sistemas.

As condições econômicas referem-se à necessidade de otimizar os custos de investimento (construção) associados aos de manutenção da estrutura em uso, e de compatibilizar esses custos com os prazos desejados.

b) Exigências de qualidade referentes a segurança e durabilidade, impostas pelas Normas Técnicas de Projeto.

As exigências técnicas de segurança e de durabilidade são as normalmente descritas nas Normas específicas e atualizadas de projeto, e referem-se à necessidade da estrutura, com grau apropriado de confiabilidade:

- resistir a todas as ações e outras influências ambientais passíveis de ocorrer durante sua fase construtiva;

- comportar-se adequadamente sob as condições previstas de uso, durante determinado tempo de existência (vida útil).

Esta confiabilidade caracteriza-se por segurança adequada contra riscos de ruptura; de instabilidade (perda de equilíbrio estático); de vibrações excessivas; de deformações inconvenientes e danosas à própria estrutura e/ou a outros elementos da construção; de fissuração excessiva com vistas à estética, estanqueidade e proteção da armadura.

Esta confiabilidade será complementada pelo atendimento às exigências que protejam e preservem a estrutura contra sua deterioração prematura, como, por exemplo, as referentes a cobrimento das armaduras; drenagem; especificações de materiais adequados e de medidas adequadas à agressividade ambiente.

A segurança e a durabilidade dependem ambas da qualidade dos detalhes das armaduras (emendas, dobramentos, ancoragens, nós de pórtico, furos, etc.), com vistas a evitar rupturas localizadas e a favorecer boas condições 
de adensamento do concreto.” Maiores detalhes sobre esses aspectos serão vistos no Capítulo 4.

A qualidade da descrição da solução adotada

“A solução estrutural adotada deve estar descrita nos Desenhos e nas Especificações, de modo a permitir a completa e perfeita execução da estrutura. Isto implica exigir que os Desenhos e Especificações contenham informações completas, claras, corretas, consistentes entre si e consistentes com as exigências já identificadas" anteriormente (LARANJEIRAS, 1993).

Conforme prescrito na revisão da NB 1 (1994), para que sejam atendidas as exigências da qualidade impostas às estruturas de concreto, é necessário que, ainda na fase de projeto, sejam adotadas hipóteses, soluções e procedimentos apropriados, bem como medidas para a garantia da qualidade. As hipóteses, as soluções e os procedimentos do projeto estrutural estão devidamente disciplinados em normas. As medidas de garantia da qualidade de projeto, ao contrário, estão ainda pouco normalizadas em nível nacional e internacional. Além disso, a literatura técnica sobre o assunto é bastante escassa, constituindo-se este trabalho numa tentativa de suprir a necessidade de bibliografia mais específica sobre o assunto. Nos itens 2.2 e 2.3, são propostas medidas elementares para garantia e controle da qualidade dos projetos estruturais.

\subsection{PRINCÍPIOS DO CONTROLE}

Muitos casos de ruína estrutural e mau desempenho em serviço de estruturas são causados por erros não detectados, cometidos ainda na fase de projeto. $\mathrm{O}$ controle da qualidade de projetos estruturais tem caráter preventivo, visando detectar erros e defeitos com o objetivo principal de corrigir suas causas e não só as ocorrências, objetivando, principalmente, a satisfação das necessidades dos usuários. Portanto, o principal propósito do controle é assegurar uma qualidade aceitável do projeto, 
através da detecção oportuna de eventuais falhas que possam comprometer a segurança, o bom desempenho em serviço e a durabilidade das estruturas.

Assim, as atividades do controle da qualidade de projetos visam, basicamente, checar:

- se a estrutura, conforme projetada, apresenta a segurança, o bom desempenho em serviço e a durabilidade requerida para o usuário que dela se beneficiará;

- se são atendidas as exigências da qualidade impostas por condições arquitetônicas, funcionais, construtivas, estruturais, de integração com os demais projetos e econômicas, como anteriormente definidas;

- se os requisitos técnicos constantes de normas são respeitados;

- se a definição da estrutura está claramente descrita nos desenhos e nas especificações.

Com relação ao projeto estrutural, um requisito fundamental refere-se à necessidade de assegurar, na fase de projeto, não só a segurança e o bom desempenho em serviço, mas também a durabilidade. A consideração das condições de exposição pode influenciar a concepção estrutural, o detalhamento, a composição do concreto, o tipo de cimento etc., e isto deve ser considerado pelos projetistas na fase inicial.

A intensidade do controle depende da importância e da complexidade do projeto, da severidade das conseqüências de possíveis falhas (incluindo o resultado de erros humanos) e das exigências de segurança estabelecidas. Um nível maior de controle é mais dispendioso, porém possibilita tomadas de decisões mais confiáveis, devido à maior eficiência na detecção de desvios em relação às hipóteses e às especificações.

LARANJEIRAS (1993) declara que "os serviços de controle da qualidade de projetos devem ser obviamente executados antes da fase de construção e, de preferência, simultaneamente com a fase de projeto, como condição essencial para que seus resultados se tornem efetivos e conseqüentes". Assim, o desenvolvimento e o controle do projeto devem caminhar paralelamente, evidenciando a existência de uma relação íntima entre os dois processos. É importante que o processo de controle 
seja executado de tal modo que não interaja desfavoravelmente com a elaboração do projeto.

LARANJEIRAS (1993) afirma ainda que "a boa qualidade de um projeto estrutural é o resultado de um trabalho integrado e associado de todos que nele estão envolvidos - pessoal de projeto e pessoal de controle da qualidade - todos profissionais competentes, honestos e de boa vontade. Portanto, a responsabilidade por se atingir esta qualidade é um compromisso a ser assumido por todo o grupo e por cada participante, em particular".

De fato, a implementação efetiva de um sistema de garantia da qualidade pressupõe a completa unificação dos objetivos de todos os envolvidos, de modo que possam ser discutidas e verificadas as questões relacionadas com a qualidade. É preciso uma consciência coletiva para a qualidade. A cooperação precisa ser a base do trabalho em conjunto. Com relação ao projeto, o primeiro aspecto a ser considerado é a necessidade de estabelecer uma boa coordenação entre os projetistas de diferentes partes do projeto: arquitetônico, estrutural, instalações etc.

De acordo com a parte que executa ou se responsabiliza pelo controle, podese distinguir: controle interno e controle externo. O controle interno é executado pelo próprio projetista ou por uma organização por ele encarregada desta tarefa. O controle externo, por sua vez, é executado por profissionais independentes daqueles que realizaram o projeto, conferindo maior credibilidade à qualidade do projeto analisado.

O tipo de controle depende do tipo de projeto. Em qualquer caso, entretanto, deve ser feito, pelo menos, um controle interno. Para estruturas de grande importância, o controle da qualidade feito pelo próprio projetista dever ser complementado por um controle interno independente, que deverá checar os desenhos antes que eles sejam liberados. Esta prática é também recomendada para estruturas usuais.

Para o controle do projeto, deve-se verificar se os requisitos e as condições usadas estão de acordo com as especificações, se os modelos de cálculo relevantes 
são empregados, se os cálculos numéricos estão corretos e, finalmente, se os desenhos e outros documentos gerados estão de acordo com os cálculos e com as especificações dadas.

\subsection{METODOLOGIA DO CONTROLE}

O projeto estrutural consiste, principalmente, de cálculos e de preparação de desenhos, especificações, memória de cálculo e documentos similares. Desenhos e especificações são o produto final do projeto; cálculos são apenas auxiliares. Entretanto, todos os elementos são importantes para a qualidade.

Os cálculos são baseados nos requisitos especificados e devem estar devidamente documentados, checados e aprovados. Os desenhos, por sua vez, baseiam-se nos resultados dos cálculos e, também, diretamente, nos requisitos especificados, devendo ser revisados e aprovados pelos responsáveis por sua geração para a correta incorporação dos cálculos do projeto.

O controle da qualidade de projetos estruturais consiste em examinar as informações contidas nos documentos gerados com o propósito de checar o atendimento às exigências da qualidade, tal como descritas no item 2.1.6, através de uma análise comparativa com os documentos de referência. Portanto, o controle de projeto consiste, basicamente, em verificar se todas as exigências e condições necessárias são satisfeitas, checar se os modelos e métodos de cálculo são apropriados e se os cálculos numéricos são efetuados corretamente e certificar-se de que os desenhos e as descrições são claramente compreensíveis e se são coerentes com os cálculos do projeto e com as especificações estabelecidas (JCSS, 1981).

A metodologia do controle, conforme apresentada a seguir, tem como referência o trabalho de LARANJEIRAS (1993). O controle da qualidade de projetos estruturais compreende as seguintes atividades:

- Identificação dos documentos de referência;

- Avaliação das informações do projeto;

- Classificação das informações do projeto;

- Realimentação do projeto; 
- Elaboração de relatório conclusivo.

\subsubsection{Identificação dos Documentos de Referência}

Inicialmente devem ser identificados e classificados todos os documentos de referência da qualidade disponíveis. Devem ser identificadas ainda as bases do projeto, tais como códigos, padrões, hipóteses e outros requisitos.

Deve-se controlar e permanentemente atualizar toda a documentação relativa à qualidade, retirando de circulação os documentos modificados e substituindo-os por suas versões mais recentes.

\subsubsection{Avaliação das Informações do Projeto}

Os desenhos são a principal ligação entre as atividades de projeto e de construção e, portanto, são, em princípio, o principal objeto do controle. Todavia, como os desenhos são baseados nos cálculos, em muitos casos, é conveniente ou necessário controlar os cálculos. Também as especificações precisam ser controladas, quando não estão incluídas nos desenhos.

\section{A. Controle dos Cálculos}

A memória de cálculo é um documento auxiliar, porém, assim como os desenhos e as especificações, igualmente importante para o controle da qualidade de projetos.

O controle dos cálculos pode ser executado por diferentes técnicas e em diferentes níveis. Entretanto, em qualquer caso, deve-se verificar:

- a concepção geral da estrutura;

- as bases para o cálculo;

- a conformidade com requisitos fundamentais e com condições ambientais e de utilização; 
- o grau de definição (checar se os cálculos são realizados para todas as partes estruturais que exigem cálculo);

- os modelos e métodos de cálculo empregados;

- discrepâncias entre diferentes partes dos cálculos;

- as ações consideradas;

- as situações de projeto, os casos de carregamento e as combinações de ações considerados;

- os coeficientes de segurança adotados;

- o desenvolvimento dos cálculos.

Três técnicas distintas, propostas pelo JCSS (1981) e também pelo CEB Bulletin d'Information n.157 (1983), podem ser usadas para verificar o desenvolvimento dos cálculos. A primeira alternativa consiste numa verificação direta total, que significa que os cálculos são acompanhados passo a passo. A vantagem deste método é que as discrepâncias são imediatamente detectadas. A desvantagem é que a pessoa que faz a verificação pode ser muito conduzida pelos cálculos. Portanto, neste caso, é necessário fazer verificações adicionais, por exemplo, para detectar qualquer omissão.

Uma outra alternativa consiste no método da verificação paralela total, em que são realizadas verificações de forma completamente independente dos cálculos do projeto e, posteriormente, os resultados dos dois cálculos distintos são comparados em determinados pontos previamente estabelecidos. Uma vantagem desse método é que a pessoa que faz a verificação não é influenciada significativamente pelo cálculo original. Outra vantagem é que, em muitos casos, as verificações podem ser feitas por métodos simplificados. A desvantagem é que se ocorrerem discrepâncias, é difícil, muitas vezes, encontrar a fonte.

O terceiro método é o da verificação parcial. Por este método, são adequadamente escolhidos pontos críticos ou elementos representativos, os quais são verificados direta ou paralelamente. Os demais resultados dos cálculos são verificados por meio de comparações. Esse método tem a vantagem de ser o mais rápido. Entretanto, é, em geral, o mais difícil e, portanto, requer uma pessoa 
experiente para realizar o trabalho. Além disso, nem sempre é possível a sua aplicação.

Se a memória de cálculo for colocada à disposição do controle da qualidade, as verificações poderão ser executadas por qualquer das três técnicas apresentadas. Caso contrário, o método da verificação parcial será o único aplicável. Neste caso, os resultados dos cálculos de componentes representativos ou críticos da estrutura, convenientemente escolhidos, são comparados com as informações contidas nos desenhos e nas especificações.

Geralmente, utiliza-se uma combinação dos três métodos mencionados. Esse é o caso, principalmente, se os cálculos são feitos por computador. Nesses casos, torna-se inconveniente, senão impossível, a realização de verificação direta.

A utilização de computadores cria não só uma nova filosofia para o projeto, como também a necessidade de alterações profundas na prática corrente com relação à apresentação dos documentos do projeto, assim como nos procedimentos de verificação destes documentos, de modo a controlar sua qualidade.

Infelizmente, tais alterações nem sempre ocorrem como seria conveniente. Percebe-se, com relativa freqüência, a inclusão de dados de saída do computador nos documentos do projeto, sem os devidos esclarecimentos e sem referências explícitas aos dados de entrada e ao próprio programa utilizado. Diante de tal constatação, torna-se evidente que uma verificação direta é praticamente impossível.

O CEB Bulletin d'Information n.157 (1983) recomenda que, em qualquer caso, as informações mais relevantes do projeto devem ser verificadas, pelo menos com relação à sua ordem de grandeza, por procedimento independente e preferencialmente simples, orientado pela experiência e bom senso, e tendo em mente que, na elaboração e no controle de um projeto, não se pode perder uma visão geral entre os resultados obtidos e os supostamente esperados. 


\section{B. Controle dos Desenhos e das Especificações}

Os desenhos devem ser elaborados de modo a facilitar o controle da qualidade do projeto e devem conter as informações necessárias para sua perfeita execução. Devem constar, ainda, referências a outros desenhos e especificações relacionados, sempre que for apropriado.

No caso de alteração de um desenho, todos os outros documentos a ele relacionados devem ser imediatamente atualizados. Além disso, deve-se informar a data e o responsável pela modificação, bem como a versão anterior que foi substituída.

O controle dos desenhos consiste, geralmente, em verificar:

- a definição geral da estrutura;

- o grau de definição (se os desenhos estão completos);

- a consistência entre as informações contidas nos diversos desenhos;

- a conformidade com requisitos fundamentais e com condições ambientais e de utilização;

- se os resultados obtidos dos cálculos são corretamente transferidos para os desenhos;

- a ambigüidade ou o risco de serem mal interpretados;

- os detalhes dos elementos;

- os detalhes construtivos;

- se todas as dimensões necessárias estão explicitamente indicadas;

- as especificações dos materiais (concreto e aço);

- definição e detalhamento de dispositivos especiais, se houver;

- em casos específicos, informações explícitas sobre posicionamento e retirada das fôrmas, processo de concretagem e tolerâncias dimensionais.

Em outras palavras, o controle da qualidade deve avaliar se as informações contidas nos desenhos e nas especificações são completas, claras, em escalas apropriadas, consistentes (entre si) e corretas, segundo prescreve LARANJEIRAS (1993). 
“As informações serão completas, claras, em escalas apropriadas e consistentes: (a) com relação à identificação do documento; (b) com relação às necessidades da administração e planejamento da obra; (c) com relação às exigências peculiares dos serviços de fôrma, escoramento, concretagem, armação, etc. As informações serão corretas se compatíveis com as ações, esforços e materiais adotados. Em outras palavras, esta atividade indica a necessidade de verificar se os resultados consubstanciados nos Desenhos e Especificações são compatíveis com as hipóteses de projeto.” (LARANJEIRAS, 1993)

A título de ilustração, apontam-se na Tabela 2.1 alguns pontos e aspectos críticos comuns em projetos estruturais de concreto armado. Salienta-se, entretanto, que cada projeto pode apresentar particularidades que os fazem diferentes dos demais e, portanto, a lista apresentada não deve ser tomada como regra geral para todos os projetos.

O CEB Bulletin d'Information n.184 (1988) sugere a utilização de listas de verificações, uma das ferramentas mais importantes da garantia da qualidade, visto que favorecem melhor desempenho nas verificações, pois ajudam a responder às indagações que decorrem das exigências da qualidade definidas. Como as listas de verificações raramente são completas e, portanto, nunca abrangem todos os aspectos, recomenda-se que o seu uso seja feito de forma consciente e não como rotinas que dispensem o esforço mental de análise do projeto. 
Tabela 2.1 - Lista de pontos e aspectos críticos comuns em projetos estruturais. (Ref. LARANJEIRAS, 1993 e CEB Bulletin d'Information n.157, 1983)

1. Deficiência de coordenação e comunicação entre os responsáveis pelo projeto estrutural e os responsáveis pelos demais projetos (arquitetônico, ar condicionado, hidráulico etc.), pelo empreendimento e pela construção.

2. Tomada de decisões não avalizadas pelos responsáveis pelo empreendimento e pela construção.

3. Inobservância das exigências de durabilidade da estrutura, com destaque, por exemplo, para as exigências atualizadas de cobrimento de armaduras, de controle de fissuração e de drenagem superficial.

4. Inobservância às exigências de controle de fissuração por deformações impostas (retração/temperatura), com destaque, por exemplo, para as exigências de taxa mínima de armadura para peças sob condições de estanqueidade e para peças de grandes dimensões.

5. Ausência de plano de concretagem, em casos em que sua definição é indispensável, com destaque, por exemplo, para estruturas sob condições de estanqueidade, com conseqüente omissão de mata-juntas.

6. Tomadas de decisões inadequadas por pessoal técnico ou auxiliar (desenhista), sem nível de conhecimento ou de experiência suficientes, como, por exemplo, não observar esconsidades, desníveis, curvaturas, implicações tridimensionais e imposições de fachadas.

7. Adoção de hipóteses (para as ações e resistências) e de métodos de cálculo inadequados ou fora de seus limites de aplicação, com destaque, por exemplo, para a freqüente inobservância do efeito relevante da fissuração na avaliação de deformações, subestimar as cargas permanentes de pisos e substituir o empuxo de repouso por empuxo ativo (solos).

8. Ausência de detalhes construtivos, tais como: distância entre as barras da armadura, comprimento de emendas, ligação viga-pilar, juntas etc.

9. Especificações insuficientes.

10. Omissão de hipóteses relevantes de carregamento (por exemplo, combinação de ações, presença de forças horizontais, fase construtiva).

11. Modelação equivocada da estrutura para efeito de análise de esforços e de deformações, como por exemplo, desconsiderar as diferenças de modelações sob carregamentos verticais e horizontais, ou tratar como planas estruturas com efeitos tridimensionais relevantes.

12. Nos casos de cálculo auxiliado por computador: falta de documentação apropriada, erros nos dados de entrada, má interpretação de alguns parâmetros de entrada e de saída etc. 
As melhores listas são sempre de caráter e formato personalizados. Assim, o controle da qualidade deve elaborar suas próprias listas para cada projeto, tomando os exemplos apresentados a seguir apenas como uma referência inicial.

As listas de verificações podem se apresentar como uma lista de perguntas ou como uma lista de itens positivos que precisam ser verificados. No primeiro caso, as perguntas devem ser formuladas de modo que somente sejam possíveis as respostas Sim, Não ou Não se aplica. Além disso, a qualidade do projeto deve estar sempre associada à resposta positiva Sim. Assim, por exemplo, a pergunta $O$ elemento apresenta fissuras? deve ser substituída por O elemento está isento de fissuras?.

Desta forma, para identificar os aspectos do projeto que não satisfazem às exigências da qualidade especificadas, basta verificar na lista se há algum registro de resposta negativa Não. As listas em forma de perguntas, portanto, têm a vantagem de possibilitar a identificação imediata da ocorrência de não-conformidades. Elas são mais apropriadas para verificar se as exigências foram, de fato, cumpridas.

As listas em forma de itens, por sua vez, são, em geral, mais adequadas ao planejamento e à preparação preliminar das verificações, dificultando a ocorrência de omissões. Elas, entretanto, não fornecem nenhuma indicação se há condições de nãoconformidade.

A seguir, são apresentados dois exemplos de listas de verificações, tabelas 2.2 e 2.3, transcritos de LARANJEIRAS (1993), referentes a um projeto de estrutura de um edifício convencional de concreto armado, sendo que a primeira lista utiliza o formato de itens e a segunda é fornecida em forma de perguntas. Outros exemplos podem ser vistos no CEB Bulletin d'Information n.184 (1988). 
Tabela 2.2 - Exemplo 1 de lista de verificações, sob o formato de itens.

Informações necessárias ao início das verificações

1. Documentos

- desenhos

- especificações

- memorial justificativo

- plano construtivo

- memória de cálculo

- projeto arquitetônico

- projeto de ar condicionado

- projeto de elevadores

- projeto de drenagem

- levantamento topográfico

- relatório de sondagens

- estudo geotécnico

- normas estruturais

* ações e segurança

* ação do vento

* fundações

* concreto armado

* aparelhos de apoio

2. Identificação da estrutura

- estrutura para resistir às ações verticais

- estrutura para resistir às ações horizontais

- juntas de movimento

- fundações

- estruturas de contenção de terras

- reservatórios inferior e superior

- estruturas de piso

- estrutura na fase construtiva 


\section{Materiais}

- concretos

- concretos de alta resistência

- aços

- aparelhos de apoio

- selantes (mástiques e mata-juntas)

- adesivos

- pinturas de proteção

4. Ações

- ações verticais

- ações horizontais

- efeitos de deformações impostas (recalque, retração e temperatura)

- combinações de ações

- superposição de ações com deformações impostas

- empuxos

- cargas de casa de máquinas dos elevadores

5. Exigências de segurança da estrutura em serviço

- rigidez e resistência às forças horizontais

- segurança à ruptura por esforços

- estabilidade de corpos rígidos (muros)

- controle de fissuração

- controle de deformações

- estanqueidade

- durabilidade

- aspectos peculiares

6. Exigências de segurança da estrutura em construção

- segurança à ruptura

- segurança à fissuração

- segurança à deformação

- aspectos peculiares 
Tabela 2.3 - Exemplo 2 de lista de verificações, sob o formato de perguntas.

\begin{tabular}{|c|c|c|c|}
\hline \multicolumn{4}{|l|}{ Verificações de plantas de formas } \\
\hline Verificações & Sim & Não & $\begin{array}{l}\text { Não se } \\
\text { aplica }\end{array}$ \\
\hline $\begin{array}{l}\text { 1. A identificação do documento está completa? } \\
\text { (proprietário, obra, título, número, revisão, datas, } \\
\text { assinaturas etc.) }\end{array}$ & & & \\
\hline $\begin{array}{l}\text { 2. Existe identificação completa da área de formas no } \\
\text { documento? }\end{array}$ & & & \\
\hline 3. Os pilares estão todos corretamente identificados? & & & \\
\hline $\begin{array}{l}\text { 4. Os pilares estão definidos completa e corretamente } \\
\text { em dimensões e locação? }\end{array}$ & & & \\
\hline 5. Todas as vigas estão corretamente identificadas? & & & \\
\hline $\begin{array}{l}\text { 6. Todas as vigas têm suas dimensões completamente } \\
\text { definidas? }\end{array}$ & & & \\
\hline $\begin{array}{l}\text { 7. As posições das vigas no piso estão completamente } \\
\text { definidas pelas cotas entre as faces das formas? }\end{array}$ & & & \\
\hline $\begin{array}{l}\text { 8. Há indicação completa das dimensões e } \\
\text { disposições dos elementos através de rebatimentos } \\
\text { e/ou cortes? }\end{array}$ & & & \\
\hline $\begin{array}{l}\text { 9. As juntas de movimento estão corretamente } \\
\text { posicionadas? }\end{array}$ & & & \\
\hline $\begin{array}{l}\text { 10. As juntas de movimento estão completamente } \\
\text { detalhadas? (selantes, aparelhos de apoio, mata- } \\
\text { juntas etc.) }\end{array}$ & & & \\
\hline 11. As juntas de concretagem estão definidas? & & & \\
\hline 12. As contraflechas estão corretamente indicadas? & & & \\
\hline ... etc. & & & \\
\hline
\end{tabular}

\subsubsection{Classificação das Informações do Projeto}

Todas as informações do projeto que foram submetidas a exame e análise comparativa com os documentos de referência da qualidade devem ser classificadas, segundo LARANJEIRAS (1993), em:

- Informações aceitas: são aquelas que não contrariam as exigências da qualidade definidas ou que, por falta de referência, não podem ser 
verificadas. Uma informação aceita representa uma condição que satisfaz os requisitos relativos à funcionalidade, incluindo aqueles de desempenho, capacidade de manutenção e adequação ao uso, e à segurança.

- Informações sob revisão: são aquelas que não satisfazem, de alguma forma, às exigências da qualidade definidas. Uma informação sob revisão traduz uma condição que contraria os requisitos relativos à funcionalidade ou à segurança, exigindo, portanto, uma ação corretiva.

As informações classificadas como sob revisão podem ser agrupadas em duas categorias, a saber:

- Não-conformidade: são todas as informações sob revisão que não atendem à alguma condição imposta em algum documento de referência oficial, conforme definido no item 2.1.5;

- Divergência: são todas as informações sob revisão que não satisfazem alguma condição imposta em algum documento de referência não-oficial (ver item 2.1.5), ou que são consideradas incorretas, incompletas, sem clareza, em escalas impróprias ou inconsistentes, segundo avaliação dos responsáveis pelo controle da qualidade.

Os aspectos do projeto que não estiverem em conformidade com as respectivas especificações devem ser imediatamente identificados e avaliados com vistas à implementação de ações corretivas, as quais podem ser propostas pelo próprio controle da qualidade. Devem ser registradas todas as condições de nãoconformidade e divergências observadas, bem como todas as informações complementares que possam auxiliar na identificação das causas de tais ocorrências.

\subsubsection{Realimentação do Projeto}

Todas as não-conformidades e divergências observadas devem ser devidamente registradas e informadas àqueles que encomendaram os serviços de controle da qualidade ou diretamente aos responsáveis pelo projeto, para que possam 
ser tomadas as devidas providências no sentido de sanar as deficiências do projeto. $\mathrm{O}$ controle da qualidade pode, inclusive, acrescentar aos registros de nãoconformidades e divergências, informações complementares, comentários e sugestões que julgar necessários e pertinentes e, ainda, propor ações corretivas de caráter preventivo para serem analisadas e, posteriormente, implementadas.

Cabe ao projetista analisar as sugestões propostas e tomar as decisões cabíveis. Quaisquer alterações no projeto, incluindo aquelas realizadas no campo, devem ser submetidas às mesmas medidas de controle aplicadas ao projeto original.

As anotações e observações feitas pelo controle da qualidade podem constar dos próprios desenhos ou constituir documento separado. Este documento pode ser anexado aos respectivos desenhos ou, alternativamente, podem ser enviados separadamente, sendo recomendado, neste caso, que sejam indicados os desenhos correspondentes a cada não-conformidade assinalada.

É de extrema importância que as responsabilidades das pessoas envolvidas no projeto e no respectivo controle da qualidade sejam explicitamente definidas. Tais responsabilidades devem ser claramente especificadas, com especial atenção dada às interfaces e à comunicação.

É importante salientar que a eficiência do controle da qualidade é diretamente influenciada pela severidade das medidas adotadas nos casos de não-conformidade.

\subsubsection{Elaboração de Relatório Conclusivo}

As atividades do controle da qualidade de projetos são finalizadas com a elaboração de um relatório conclusivo, onde os profissionais encarregados pelo controle apresentam os resultados obtidos nas verificações desenvolvidas.

Devem ser mantidos registros da qualidade como evidência de que as atividades do controle foram devidamente executadas. Esses registros devem ser fornecidos àqueles que encomendaram o controle da qualidade e preservados por um determinado período de tempo após a conclusão do projeto. 
Após a entrega e análise do relatório, podem ser promovidas reuniões para que sejam discutidas as causas das não-conformidades e divergências porventura encontradas, de modo a definir as medidas corretivas a serem aplicadas com a finalidade de corrigir as deficiências de projeto e evitar, assim, problemas futuros de desempenho da estrutura analisada.

O relatório deve identificar os aspectos do projeto que não estão em conformidade com as exigências da qualidade e os respectivos documentos de referência. Assim, no relatório devem constar a identificação do projeto analisado, a relação de documentos de referência utilizados e as avaliações realizadas pelo controle da qualidade com relação às exigências da qualidade, incluindo o registro de todas as não-conformidades e divergências observadas e a listagem de sugestões e comentários que, por sua relevância, devam ser considerados na revisão do projeto. 


\section{DETERIORAÇÃO DO CONCRETO}

O termo deterioração é aqui empregado como antônimo de durabilidade, definida como a capacidade do material suportar as condições para as quais foi concebido, sem sofrer danos significativos ao longo de um determinado período.

Os porquês de tantos problemas relativos à durabilidade das estruturas constituem tema bastante abrangente, que envolve diversos parâmetros. Um deles consiste no aumento da esbeltez dos elementos estruturais, propiciado pela utilização de materiais mais resistentes. Nas obras antigas, sendo empregados concretos de baixa resistência, as seções transversais dos elementos eram, em geral, mais robustas, assim como o cobrimento das armaduras.

De fato, a evolução da tecnologia dos materiais, observada nos últimos anos, conduziu a um aumento das resistências, principalmente do concreto. Inúmeros são os pesquisadores que realizam estudos no sentido de desenvolver técnicas para obtenção de concretos com melhor desempenho, seja em termos de baixa permeabilidade e porosidade, seja em termos de maior ductilidade e resistência. Neste contexto, destacam-se, por exemplo, o concreto com fibras e o concreto com adição de sílica ativa, material que proporciona ganho de resistência. Nos dias atuais, observa-se uma clara tendência no crescimento do emprego de concretos de alto desempenho, com resistências cada vez maiores.

A consequiência direta do aumento da esbeltez dos elementos estruturais é o surgimento de problemas relacionados à durabilidade das estruturas e o inevitável comprometimento da sua qualidade. As estruturas mais esbeltas são mais vulneráveis às influências ambientais, justificando, assim, o fato de construções antigas apresentarem bom desempenho e aparência aceitável muitos anos após a sua 
execução, enquanto outras mais recentes mostram sinais visíveis de deterioração prematura.

Um outro parâmetro que pode ajudar a justificar a frequiente ocorrência de problemas relacionados com a durabilidade, considerado de extrema significância, refere-se ao critério inadequado de aceitação das estruturas, baseado unicamente na resistência do concreto. É fato que a durabilidade do concreto depende muito mais da sua permeabilidade e capacidade de absorção, propriedades condicionadas pela porosidade, do que das propriedades universalmente aceitas, tais como: resistência, módulo de elasticidade, slump, massa específica etc.

Este critério mostrou-se eficiente por algum tempo, quando o cimento empregado apresentava baixa resistência. Para produzir um concreto com uma determinada resistência era necessário utilizar uma quantidade significativa de cimento, conduzindo, desta forma, a um concreto de alta densidade. Assim, podia-se dizer que um concreto resistente era também durável, embora a durabilidade não tivesse sido, em momento algum, explicitamente considerada.

Nos dias atuais, o cimento empregado possui maior resistência do que aqueles utilizados no passado. Portanto, pode-se utilizar menor quantidade deste material na mistura e maior relação água-cimento para obter a mesma resistência aos 28 dias. $\mathrm{O}$ concreto assim produzido é menos denso e, conseqüentemente, mais permeável. Pelo critério da resistência este concreto seria aceito, ao passo que a durabilidade poderia estar seriamente comprometida, a depender do nível da agressividade ambiental.

Pelas razões anteriormente expostas, verifica-se a necessidade de superar a filosofia primitiva que considera a segurança o único fator importante, deixando a durabilidade em segundo plano. As normas técnicas brasileiras, em vigor, praticamente não tratam deste critério. É preciso que haja maior preocupação com a durabilidade das estruturas e que sejam concentrados maiores esforços no desenvolvimento de critérios, a serem aplicados em forma de especificações de projeto, de modo a garantir a produção de estruturas duráveis. 
A preocupação com a durabilidade inadequada das estruturas de concreto motivou a realização de intensas pesquisas sobre as causas e a natureza dos processos de degradação. Os resultados de tais pesquisas favoreceram o desenvolvimento de estratégias para combater as situações desfavoráveis.

Neste contexto, destacam-se as atividades desenvolvidas pelo Comité EuroInternational du Béton (CEB), cujas publicações fornecem valiosas providências a serem tomadas no intuito de prevenir os problemas relativos à deterioração prematura das estruturas. Cita-se, como exemplo, o Bulletin d'Information n.182 (1989), que descreve, de forma detalhada, os principais fatores responsáveis pelo desencadeamento de mecanismos de deterioração das estruturas, recomendando as respectivas medidas preventivas. Outro exemplo é o CEB-FIP Model Code 1990 (1993), que condensa os resultados de inúmeras investigações desenvolvidas pelo CEB desde 1978, com relação à durabilidade e à vida útil de estruturas novas ou existentes.

Também merece destaque o desempenho do American Concrete Institute (ACI) na tentativa de buscar soluções para melhorar a durabilidade do concreto. Os resultados das diversas pesquisas realizadas encontram-se documentados em publicações como o ACI 201.2R (1992).

Todas as pessoas envolvidas no processo construtivo deveriam ter um mínimo de conhecimento sobre os mais importantes processos de deterioração e dos parâmetros que os governam, como pré-requisito básico para tomada de decisões corretas na busca pela durabilidade das estruturas.

Por esta razão, este capítulo contém a base teórica referente aos principais mecanismos de deterioração das estruturas e dos materiais que as compõem, indicando-se as condições que propiciam o seu desencadeamento e apontando-se as medidas preventivas mínimas. Não se pretende aprofundar no campo da ciência e tecnologia dos materiais, mas sim apresentar noções gerais em modelos simplificados, com o objetivo de fornecer informações básicas e essenciais para projetistas e construtores. Maiores detalhes poderão ser encontrados nas referências bibliográficas. 


\subsection{MECANISMOS DE TRANSPORTE}

Na maioria dos processos físicos e químicos que podem afetar a durabilidade das estruturas de concreto, dois fatores predominantes estão envolvidos, a saber: os mecanismos de transporte através dos poros e das fissuras e a presença de água.

Gases, líquidos e substâncias dissolvidas podem ser transportados dentro da massa do concreto endurecido ou na troca com o meio ambiente através de três mecanismos básicos: difusão, sucção capilar e penetração por pressão hidráulica. Tais mecanismos são, a seguir, ilustrados de forma sucinta, utilizando-se como referência, três condições ambientais características: ambiente úmido, região de chuvas e imersão.

Em um ambiente úmido, dependendo da umidade relativa do ar, os poros maiores da massa endurecida de concreto encontram-se parcialmente preenchidos por ar. A superfície desses poros é revestida por uma película de água aderida por adsorção. Neste ambiente, a difusão é o principal mecanismo de transporte. A difusão é um processo induzido por uma tendência ao equilíbrio quando há diferenciais de concentração de determinada substância. Este processo se aplica a líquidos, gases e substâncias dissolvidas em meio líquido.

Quando as superfícies de concreto são molhadas, como ocorre quando há chuvas, os poros podem atingir rapidamente o nível de saturação, devido à sucção capilar provocada pelo excedente de água. Neste caso, o transporte de gases fica praticamente impedido. Vale ressaltar que a água é absorvida pelo concreto numa velocidade muito maior do que é liberada por evaporação.

No caso de estruturas submetidas a imersão, a penetração da água se inicia por sução capilar, possivelmente acelerada por pressão hidráulica. Uma grande quantidade de água poderá ser continuamente transportada, desde que haja uma superfície exposta ao ar, por onde a água possa evaporar. Esta água pode carregar agentes dissolvidos (tais como, cloretos, sulfatos etc.), os quais são deixados no concreto nas regiões onde ocorre a evaporação, podendo ocasionar altos níveis de 
concentração. Tais agentes, inicialmente dissolvidos, cristalizam-se nas superfícies do concreto, acarretando eflorescências. No concreto, as forças expansivas devidas à cristalização de sais apenas causam pequenos problemas. Muito mais significativo é o efeito químico da concentração de substâncias agressivas.

Juntamente com as condições ambientais (umidade e temperatura) nas proximidades das superfícies expostas de concreto, a estrutura dos poros e a configuração das fissuras são os principais fatores intervenientes na velocidade, na extensão e nos efeitos dos mecanismos de transporte. De fato, dentre os diversos parâmetros envolvidos nos processos de deterioração do concreto, a porosidade e a fissuração se destacam como principais agentes condicionantes da vulnerabilidade do concreto ao ataque por processos químicos e físicos.

O concreto é um material poroso devido à impossibilidade de preencher todo o seu volume com sólidos, sendo esta porosidade medida não só pelo volume de vazios na massa endurecida, mas também pelo tipo, tamanho e distribuição desses poros.

No concreto, a parte mais sensível ao ataque é a pasta de cimento, cuja porosidade vai influir fundamentalmente na sua intensidade. Numa pasta densa, o ataque é essencialmente limitado à superfície, prosseguindo lentamente com o tempo para o interior. Uma pasta porosa, ao contrário, favorece a penetração das soluções agressivas, que, agindo no interior da massa, tornam o ataque mais intensivo.

Permeabilidade e capacidade de absorção são propriedades do concreto diretamente relacionadas com a sua resistência ao ataque químico ou ao congelamento da pasta de cimento. A durabilidade do concreto é essencialmente condicionada por essas duas propriedades, ambas diretamente influenciadas pela porosidade.

A permeabilidade é a propriedade do concreto de permitir a passagem de água através do material. A capacidade de absorção, por definição, é a propriedade que tem o concreto de reter água nos condutos capilares e nos poros. Enquanto a absorção é função do volume de poros e canais que têm ligação com a superfície 
exterior, a permeabilidade depende da estrutura dos poros como um todo, isto é, do tamanho, da distribuição e da continuidade dos poros.

Todos os fatores que afetam a porosidade do concreto interferem também na sua permeabilidade e capacidade de absorção e, portanto, na sua resistência ao ataque químico. Dentre estes fatores, destacam-se: relação água/cimento; quantidade, composição e finura do cimento; quantidade, forma e dimensões dos agregados; grau de hidratação do cimento; aderência entre a pasta e o agregado; presença e quantidade de adições e de aditivos; qualidade da execução etc.

Com vistas à durabilidade do concreto, devem ser tomadas providências para garantir baixo índice de permeabilidade. Juntamente com uma execução cuidadosa do concreto, a adoção de baixa relação água-cimento e de um certo teor mínimo de cimento na dosagem são as medidas mais eficazes para este fim, pois garantem alta densidade para o concreto.

A qualidade da execução do concreto, principalmente com relação às atividades de mistura, transporte, lançamento, adensamento e cura, é extremamente importante para minimizar a permeabilidade, evitando-se segregações, exsudação excessiva e formação de fissuras.

A utilização de aditivos plastificantes ou incorporadores de ar é uma forma de reduzir a permeabilidade, uma vez que esses aditivos permitem a redução da quantidade de água na mistura, para uma mesma trabalhabilidade. A utilização de cimentos pozolânicos e de alto forno também contribui para a redução da permeabilidade.

A fissuração, assim como a porosidade, também proporciona facilidades para que os agentes agressivos penetrem no concreto e iniciem sua ação destruidora na estrutura. As fissuras vão ocorrer sempre que a tensão de tração no concreto for maior do que a sua resistência à tração, que é reconhecidamente bastante baixa. Nas linhas que se seguem, apresentam-se os tipos de fissuras que ocorrem com maior frequiência na prática. 
Diversas são as circunstâncias que podem provocar fissuração do concreto. As fissuras podem surgir mesmo antes da aplicação do carregamento e, inclusive, antes do endurecimento da massa. Elas podem ser causadas por movimentos gerados dentro do próprio concreto (assentamento plástico diferencial, retração plástica superficial, retração por secagem, movimentações de origem térmica), por expansão de materiais embutidos no concreto (corrosão das armaduras, reações álcaliagregado) ou ainda por condições externas impostas (carregamentos excessivos, vibrações não previstas no projeto, armaduras insuficientes ou mal posicionadas, recalque diferencial do solo de fundação), dentre outras causas.

As fissuras que ocorrem antes do endurecimento da massa, geralmente, resultam de assentamento plástico diferencial ou de retração plástica superficial. A formação dessas fissuras está relacionada diretamente com a exsudação, fenômeno caracterizado pelo deslocamento da água da mistura em direção à superfície, e com a velocidade de evaporação desta água.

As fissuras devidas a assentamento plástico diferencial ocorrem quando há algum impedimento (proporcionado, por exemplo, pela presença de armadura ou de agregados muito grandes) ao assentamento da massa do concreto ainda plástico na fôrma. $\mathrm{O}$ assentamento dos materiais que compõem o concreto se deve à ação da gravidade e provoca o deslocamento da água e do ar não excluído pela vibração em direção à superfície. Tais fissuras podem ser evitadas mediante dosagem bem proporcionada com o mínimo slump praticável e adensamento adequado, que pode, inclusive, incluir revibração depois que as fissuras ocorrem.

As fissuras por retração plástica superficial podem ocorrer se houver impedimento ao decréscimo de volume causado por evaporação excessivamente rápida da água da superfície quando o concreto ainda é plástico e não possui resistência. Tais fissuras começam a se formar quando o brilho da água desaparece da superfície do concreto, se a perda de água por evaporação for maior do que a quantidade de água provida pela exsudação. Para prevenir o aparecimento dessas fissuras, recomenda-se controlar a temperatura do concreto quando a concretagem se 
dá em tempo quente, reduzir a velocidade do vento na superfície exposta e aumentar a sua umidade.

As fissuras que ocorrem após o endurecimento da massa, porém antes de serem aplicadas as cargas, podem resultar de retração por secagem, movimentações de origem térmica ou de outras causas, tais como: reações álcali-agregado, corrosão das armaduras, ciclo gelo/degelo, ciclo alternado de molhagem e secagem, recalques diferenciais do solo de fundação etc.

A retração por secagem corresponde a uma deformação do concreto a longo prazo, independentemente de aplicação de cargas, decorrente de redução do seu volume devido a perda de água por evaporação. Fissuras podem se formar se houver restrições ao movimento produzido pela retração. Para evitá-las, recomenda-se dispor armadura especial para controle de fissuração, reduzir a relação água/cimento, promover cura adequada e utilizar juntas de contração convenientemente espaçadas.

Movimentações de origem térmica são causas freqüentes de fissuras. Nas primeiras idades do concreto, devido ao calor liberado durante a hidratação do cimento, são gerados gradientes de temperatura entre o interior da massa e a superfície externa em contato com o ambiente. Este gradiente pode causar tensões capazes de provocar fissuração. Reduzir a temperatura do concreto durante o lançamento e controlar o calor de hidratação são medidas que auxiliam no combate à formação dessas fissuras.

As movimentações de origem térmica podem ocorrer, também, nas estruturas em serviço. Um exemplo típico é representado pelas lajes de cobertura, submetidas a distribuições não uniformes de temperatura, decorrentes de variações climáticas durante o dia. Esta situação pode gerar tensões suficientes para causar fissuras, as quais, se não forem controladas por armadura adequada, podem ser consideradas inaceitáveis. 
As fissuras excessivas que ocorrem após a aplicação do carregamento são devidas a falhas estruturais causadas por cargas excessivas ou vibrações não previstas no projeto, armaduras mal posicionadas ou insuficientes etc. Tais fissuras podem ser controladas mediante projeto bem elaborado.

Percebe-se, do exposto, que o concreto, para ser durável, deve possuir elevada compacidade e ter sua fissuração controlada.

\subsection{MECANISMOS DE DETERIORAÇÃO}

$\mathrm{O}$ concreto endurecido apresenta muitas propriedades semelhantes às das rochas. Uma das poucas exceções é a resistência ao ataque químico, sendo menor para o concreto devido à suscetibilidade da pasta de cimento.

Em princípio, a deterioração do concreto pode ocorrer a partir da degradação da pasta, do agregado ou de ambos. Na prática, entretanto, a degradação da pasta é apontada como a principal causa, uma vez que, sendo o agregado um tipo de rocha, possui maior resistência ao ataque químico. Além disso, os danos na pasta são, em geral, mais severos do que nos agregados.

A deterioração do concreto é iniciada, geralmente, por processos químicos, embora fatores físicos e mecânicos também possam estar envolvidos, em combinação ou não com os processos químicos.

Numa classificação geral, podem-se distinguir dois tipos básicos de deterioração: mecânica e química. Os mecanismos de deterioração mecânica referem-se à estrutura propriamente dita. São todos aqueles relacionados às ações mecânicas, movimentações de origem térmica, impactos, ações cíclicas, deformação lenta (fluência), relaxação e outros. Os processos de deterioração química, por sua vez, referem-se aos materiais componentes da estrutura, ou seja, podem estar relacionados ao concreto ou à armadura. 
Numa classificação mais detalhada, podem-se distinguir outros tipos de deterioração, como, por exemplo, os desencadeados por processos físicos, biológicos ou ainda, eletroquímicos, como é o caso da corrosão de metais embutidos no concreto.

Os mecanismos de deterioração química são desencadeados a partir do momento em que alguma substância nociva penetra no interior do concreto, através da superfície dos elementos. Para ser agressivo, ou seja, para produzir danos significativos, o agente químico deve se apresentar em concentrações acima de determinados limites de tolerância. Para uma dada concentração, o agente agressivo pode causar danos de diferentes magnitudes, a depender de outros fatores predominantes. Dentre os fatores que reduzem a resistência do concreto (ou da pasta) à deterioração, citam-se: alta porosidade, permeabilidade e capacidade de absorção, tipo de cimento impróprio, cura insuficiente, ciclo molhagem/secagem, altas temperaturas etc.

O transporte simultâneo de calor, umidade e substâncias químicas, tanto na troca com o meio ambiente como dentro da própria massa de concreto, e os parâmetros que controlam esses fenômenos são os principais fatores relacionados com a durabilidade. A presença de água (ou umidade) é o fator mais importante nos mecanismos de transporte, influindo em vários tipos de deterioração, excluída a deterioração mecânica.

O caráter e a intensidade dos efeitos das ações químicas na deterioração da pasta de cimento dependem tanto da composição química quanto da estrutura interna da própria pasta endurecida. O transporte da água dentro do concreto é determinado pela estrutura dos poros e também pela configuração das fissuras, conforme dito anteriormente. Assim, controlar a natureza e a distribuição dos poros e das fissuras torna-se tarefa essencial para atender aos requisitos de durabilidade das estruturas. Daí a importância de controlar a execução, principalmente durante as atividades de lançamento, adensamento e cura do concreto. 
O transporte ou o fluxo de água dentro do concreto, entretanto, não se realiza apenas através dos poros capilares da pasta, mas também através das microfissuras internas e das interfaces porosas entre o agregado graúdo e a pasta de cimento.

O CEB-FIP Model Code 1990 (1993) afirma que, de modo geral, quase todos os mecanismos de deterioração desenvolvem-se no tempo, segundo um modelo simples de duas etapas de envelhecimento, conforme indicado na Figura 3.1. Observa-se, nesta figura, a existência de duas fases distintas, denominadas Fase de Iniciação e Fase de Propagação.

\section{Durante a Fase de Inicia-} ção, não há sinais visíveis de deterioração, nem perda significativa da resistência dos materiais ou da função da estrutura, mas algumas barreiras de proteção são vencidas pela agressividade do ambiente. Já na Fase de Propagação, a deterioração evolui ativamente, em muitos casos de forma bastante rápida,

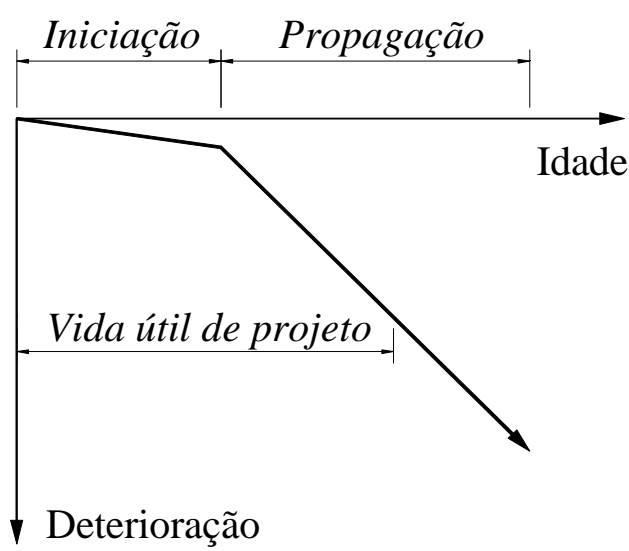

Figura 3.1 - Desenvolvimento da deterioração com o tempo.

deixando-se perceber geralmente

por sinais externos.

As medidas de proteção disponíveis atuam de duas formas no sentido de retardar a deterioração das estruturas e dos materiais, a saber: prolongando, tanto quanto possível, a Fase de Iniciação ou assegurando uma velocidade relativamente baixa na Fase de Propagação, se esta for atingida. Desta forma, pode-se projetar uma estrutura, de modo que ela possa alcançar a vida útil prevista (maiores detalhes sobre vida útil de projeto serão vistos no Capítulo 4). 


\subsection{PROCESSOS QUÍMICOS}

Algumas substâncias encontradas no meio ambiente podem penetrar na massa do concreto endurecido e, sob condições propícias de umidade e temperatura, provocar reações químicas com efeitos nocivos. O concreto, em geral, possui baixa resistência à degradação causada por processos químicos. Felizmente, apenas uma pequena parte das estruturas são expostas a ataque químico grave.

Em linhas gerais, a resistência do concreto à ação química varia com o tipo de cimento. Em ordem crescente de resistência, citam-se: cimento Portland comum e de alta resistência inicial, cimento Portland de alto forno ou de baixo calor de hidratação, cimento Portland resistente aos sulfatos ou pozolânico, cimento supersulfatado e cimento aluminoso. Esta classificação, no entanto, não deve ser tomada como regra geral.

Os mecanismos mais comuns de deterioração química são: ataques por sulfatos, água do mar, ácidos, águas puras e gás carbônico agressivo e reações com agregados.

\subsubsection{Ataque por Sulfatos}

Os sulfatos podem ser considerados elementos muito agressivos. Quando sólidos, esses sais não atacam o concreto. Porém, quando em solução, os sulfatos de magnésio, cálcio, sódio, potássio e amônio podem reagir com a pasta de cimento endurecida e levar à total desagregação do concreto.

Os sulfatos podem ser encontrados em solos (ex.: argilas), dissolvidos em águas de lençol freático, em aterros contendo resíduos industriais (ex.: escória) e também na água do mar. $\mathrm{O}$ ataque por sulfatos contidos na água do mar é menos severo do que por sulfatos dissolvidos em água freática, devido à presença de cloretos que amenizam os efeitos das reações, conforme será visto no item 3.3.2. 
$\mathrm{O}$ ataque se dá pelas reações dos sulfatos com o hidróxido de cálcio livre $\left(\mathrm{Ca}(\mathrm{OH})_{2}\right)$ e com os aluminatos de cálcio hidratados $\left(3 \mathrm{CaO} \cdot \mathrm{Al}_{2} \mathrm{O}_{3} \cdot 12 \mathrm{H}_{2} \mathrm{O}\right.$ ou, simplesmente, $\mathrm{C}_{3} \mathrm{~A}$ ), resultantes da hidratação do cimento. Os produtos dessas reações, respectivamente, o gesso $\left(\mathrm{CaSO}_{4} \cdot 2 \mathrm{H}_{2} \mathrm{O}\right)$ e o sulfo-aluminato de cálcio conhecido por etringita ou Sal de Candlot $\left(3 \mathrm{CaO} \cdot \mathrm{Al}_{2} \mathrm{O}_{3} \cdot 3 \mathrm{CaSO}_{4} \cdot 31 \mathrm{H}_{2} \mathrm{O}\right)$, cristalizam-se com a água num processo acompanhado por aumento de volume. Esta expansão é seguida de fissuração progressiva de configuração irregular, facilitando o acesso de novas soluções de sulfato. Pode ocorrer, também, desprendimento de lascas. $\mathrm{O}$ concreto adquire uma aparência esbranquiçada característica.

A velocidade com que se dá o ataque por sulfatos depende de diversos fatores, dentre eles: concentração de sulfatos na solução, permeabilidade do concreto, tipo de cimento e quantidade de água disponível para o processamento das reações.

Além dos fatores citados, a velocidade do ataque depende também da velocidade com que o sulfato é reposto. Sob condições estáticas, o ataque será muito menos severo do que em situações em que a água contaminada se encontra em movimento. A situação será ainda mais grave se o concreto estiver exposto de um só lado à pressão da água.

A vulnerabilidade dos concretos ao ataque por sulfatos pode ser reduzida desde que sejam tomadas algumas providências, dentre as quais:

$\Rightarrow$ Empregar cimentos resistentes a sulfatos. Existe uma correlação entre a resistência do cimento aos sulfatos e a quantidade de $\mathrm{C}_{3} \mathrm{~A}$ em sua composição. Cimentos com teor de $\mathrm{C}_{3} \mathrm{~A}$ abaixo de $5 \%$ são considerados altamente resistentes aos sulfatos. Este limite passa para 8\% para cimentos de moderada resistência aos sulfatos.

$\Rightarrow$ Utilizar pozolanas como adição no cimento, aditivo no concreto ou substituindo parcialmente o cimento na mistura. Além dos efeitos benéficos com relação à redução da permeabilidade, as pozolanas combinam com o hidróxido de cálcio livre e, assim, reduzem o potencial para formação de gesso. O uso de pozolanas, entretanto, requer cuidados 
especiais. Antes de expor o concreto aos sulfatos, deve-se dispor tempo suficiente para permitir o desenvolvimento da atividade pozolânica. Um teor inadequado de pozolanas, principalmente quando se utiliza cimento resistente a sulfatos, pode interferir na hidratação dos aluminatos de cálcio, conduzindo a resultados desfavoráveis.

$\Rightarrow$ Minimizar a permeabilidade do concreto (ver item 3.1). Na verdade, com relação à resistência a sulfatos, a permeabilidade deveria ser expressa em termos de valores limites para profundidade de penetração da água. Por motivos práticos, entretanto, a permeabilidade costuma ser traduzida através de valores limites para relação a/c e teor de cimento ou, ainda, através de especificação de classe mínima para o concreto. Ver, por exemplo, as indicações no item 4.4.2.

\subsubsection{Ataque por Água do Mar}

A água do mar contém diversos sais dissolvidos em concentrações bastante variadas, sendo maiores em regiões de clima quente, onde os efeitos do ataque podem ser bastante severos em apenas alguns anos. Os sais que se apresentam em quantidades significativas e que podem afetar a durabilidade do concreto são: cloretos de sódio, magnésio e potássio e sulfatos de magnésio, cálcio e potássio, sendo o teor de cloretos muito maior do que o de sulfatos. Além dos sais, a água do mar contém ainda oxigênio e dióxido de carbono dissolvidos, em quantidades que variam com as condições locais.

O ataque do concreto pelos sulfatos contidos na água do mar se dá de forma similar ao que foi descrito no item 3.3.1, porém a presença dos cloretos altera a extensão e a natureza das reações químicas, amenizando seus efeitos. O que ocorre é que há uma tendência a formar inicialmente um cloro-aluminato, conhecido por Sal de Fridell, de modo que o comportamento expansivo associado à formação do sulfoaluminato fica inibido. Além disso, o gesso e o sulfo-aluminato são mais solúveis em soluções de cloreto do que em água e são, portanto, lixiviados pela água do mar. Desta forma, a expansão produzida é menor para um cimento com mesmo teor de 
$\mathrm{C}_{3} \mathrm{~A}$. Por esse motivo, a água do mar, que deveria ser classificada como altamente agressiva devido ao seu alto teor de sulfatos, é considerada apenas como moderadamente agressiva.

A solução salina penetra no concreto e é transportada por efeito capilar até regiões acima da linha d'água, onde então ocorre a evaporação, seguida de cristalização dos sais nos poros do concreto, podendo resultar em degradação. Para que isso ocorra é preciso que o concreto seja permeável.

Além do ataque químico e da cristalização de sais nos poros, podem ocorrer outras ações destrutivas decorrentes de congelamento, impacto e abrasão das ondas, ataque biológico e, principalmente, corrosão de metais embutidos no concreto.

Num ambiente marinho, podem-se distinguir, basicamente, cinco zonas de exposição, como se descreve a seguir. Para cada zona, correspondem riscos específicos de deterioração. É importante ressaltar que, em geral, não existem limites bem definidos entre as zonas.

\section{Zona Atmosférica}

Nesta zona, o concreto nunca está em contato direto com a água do mar. Os sais são levados até as estruturas pelo vento. Os mecanismos de deterioração mais freqüentes são: corrosão de metais embutidos no concreto e congelamento.

\section{Zona de Respingos da Maré}

Esta zona situa-se acima do nível de maré alta e está sujeita a molhagem direta por ondas e respingos. Nela pode ocorrer corrosão de metais embutidos no concreto, abrasão causada pelas ondas e congelamento.

\section{Zona de Variação da Maré}

Esta zona situa-se entre os níveis de maré alta e baixa. O concreto fica submerso em determinados períodos durante o dia. Abrasão causada pelas ondas, corrosão de metais embutidos no concreto, congelamento, ataque biológico e químico são as formas de deterioração mais freqüentes. 


\section{Zona Submersa}

Esta zona localiza-se abaixo do nível de maré baixa, em que o concreto fica permanentemente submerso. Os mecanismos de deterioração predominantes são ataques químico e biológico.

\section{Zona do Leito do Mar}

Nesta zona predominam os mesmos mecanismos de deterioração que ocorrem na zona submersa.

O risco de corrosão de armaduras é maior nas zonas $\mathbf{1}$ e $\mathbf{2}$ e diminui rapidamente abaixo da linha de maré alta, sendo bastante reduzido na zona 4 . $\mathrm{Na}$ zona 3, sendo o concreto sujeito a ciclo constante de molhagem e secagem e lembrando-se que a água evapora muito mais lentamente do que é absorvida, o concreto está quase sempre saturado, o que dificulta a difusão do oxigênio necessário para a instalação da corrosão. Na zona 4 , além do fato citado, acrescente-se a baixa concentração de oxigênio na água. Maiores detalhes sobre a corrosão de metais embutidos no concreto podem ser vistos no item 3.7.

Em contrapartida, os riscos de ataque químico são maiores na região inferior da zona 3 e nas zonas 4 e $\mathbf{5}$. Entretanto, o ataque químico por água do mar não chega a ser problemático, devido à interferência dos cloretos nas reações expansivas dos sulfatos, como mencionado. Além dos sulfatos e cloretos, o gás carbônico dissolvido também pode causar reações prejudiciais, como será descrito no item 3.3.5.

Para estruturas situadas em ambientes marinhos, recomendam-se as seguintes providências principais:

$\Rightarrow$ Minimizar a permeabilidade do concreto (ver item 3.1). A relação águacimento deve ser mantida abaixo de 0,5 (CEB Bulletin d'Information n.182, 1989). 
$\Rightarrow$ Escolher adequadamente o tipo de cimento, lembrando-se que os aluminosos, de alto forno e pozolânicos são considerados resistentes aos sulfatos. Cimentos com baixo teor de $\mathrm{C}_{3} \mathrm{~A}$, embora sejam resistentes aos sulfatos, são mais permeáveis aos íons cloreto. Tendo em vista a proteção das armaduras contra a corrosão, o CEB Bulletin d'Information n.182 (1989) sugere adotar teores de $\mathrm{C}_{3} \mathrm{~A}$ entre $5 \%$ e $10 \%$.

$\Rightarrow$ Atentar para aspectos referentes a projeto e execução de juntas, de modo a assegurar que a fissuração seja mínima.

$\Rightarrow$ O ACI 201.2R (1992) recomenda adotar resistência característica mínima do concreto à compressão igual a $35 \mathrm{MPa}$.

$\Rightarrow$ Dispor cobrimento adequado para as armaduras (ver item 4.4.3). Valores maiores devem ser adotados em casos de abrasão. Na zona submersa o cobrimento pode ser menor.

$\Rightarrow$ Promover proteção direta das superfícies de concreto expostas através de revestimentos apropriados.

\subsubsection{Ataque por Ácidos}

Em geral, concretos de cimento Portland não apresentam boa resistência aos ácidos, embora alguns ácidos mais fracos sejam tolerados, especialmente se a exposição for eventual. Felizmente, a ocorrência de soluções ácidas na natureza é limitada quando comparada, por exemplo, com aquelas que contêm sulfatos.

A ação de ácidos capazes de produzir danos significativos na pasta de cimento não é comum e a agressão só se manifesta, na prática, para pH inferior a 6,5. Nenhum concreto resiste a soluções com pH menor ou igual a 3 por muito tempo. Nestes casos, torna-se necessária uma proteção especial.

Dentre os ácidos que atacam o concreto, citam-se: ácidos sulfúrico, nítrico, clorídrico, lático, acético, tartárico, fluorídrico, oxálico e fosfórico. 
A deterioração do concreto por ácidos, sejam eles orgânicos ou inorgânicos, resulta, principalmente, de reações entre esses elementos e os compostos de cálcio do cimento endurecido - silicato, aluminato e hidróxido de cálcio -, os quais são convertidos a sais de cálcio. A ação do ácido clorídrico, por exemplo, conduz à formação do cloreto de cálcio, assim como o ataque por ácido nítrico resulta em nitrato de cálcio e assim sucessivamente. Agregados de calcário e dolomíticos também podem ser atacados por ácidos.

$\mathrm{Na}$ maioria dos casos, o resultado das reações químicas é a formação de compostos de cálcio solúveis em água, os quais podem ser facilmente lixiviados, resultando em perda da capacidade de ligação entre os constituintes do concreto. Os ácidos tartárico, fluorídrico, oxálico e fosfórico são exceções, pois não são prejudiciais, uma vez que os sais que se formam são praticamente insolúveis em água e não são facilmente removidos.

Em ambientes úmidos, $\mathrm{CO}_{2}, \mathrm{SO}_{2}$ e outros gases ácidos presentes na atmosfera podem atacar o concreto, dissolvendo e removendo parte do cimento endurecido. Águas provenientes de algumas minas e de indústrias também podem conter ou formar ácidos que atacam o concreto.

Em tubulações de esgoto, especialmente a temperaturas mais altas, bactérias anaeróbias transformam os compostos de enxofre em sulfeto de hidrogênio $\left(\mathrm{H}_{2} \mathrm{~S}\right)$. Este processo só ocorre se houver teor razoável de enxofre nos dejetos, se a temperatura estiver entre $15^{\circ} \mathrm{C}$ e $38^{\circ} \mathrm{C}$, se o $\mathrm{pH}$ estiver entre 5,5 e 8,5 e, finalmente, se não houver oxigênio livre no esgoto. $\mathrm{O} \mathrm{H}_{2} \mathrm{~S}$ não é, por si só, um agente agressor. Entretanto, desprende-se do esgoto e, sob determinadas condições de umidade, sofre oxidação pela ação de bactérias aeróbias e é convertido a ácido sulfúrico.

O ataque se processa acima do nível de líquido na tubulação de esgoto e, por isso, maior atenção deve ser dada a estas superfícies. A cloração e a ventilação do esgoto, bem como o uso de agregados calcários são providências que têm sido adotadas com êxito. 
O ácido sulfúrico pode ser formado também a partir de gases sulfurosos provenientes da queima de combustíveis, a partir da oxidação do sulfeto de ferro (pirita) presente em determinados tipos de solos (como por exemplo, turfa e argila) ou em águas de poço ou ainda pela ação de bactérias em algumas águas minerais com grandes concentrações de dióxido de carbono, sulfeto de hidrogênio ou ambos, ocorrendo um fenômeno semelhante ao que se dá nos esgotos.

No caso do ácido sulfúrico, a deterioração é acelerada, pois a formação de sulfato de cálcio afeta o concreto conforme mecanismos descritos no item 3.3.1.

O concreto também é atacado por águas contendo gás carbônico livre, como as provenientes de terrenos pantanosos, as que percorrem montanhas e até mesmo a água potável. O ataque por essas águas fica limitado à superfície, desde que o concreto seja de boa qualidade e tenha baixa capacidade de absorção. A ação do $\mathrm{CO}_{2}$ será detalhada no item 3.3.5.

$\mathrm{O}$ pH isoladamente não é um bom indicador do potencial de ataque da solução ácida. A presença do $\mathrm{CO}_{2}$ também tem influência sobre a situação. A evolução do ataque é influenciada, principalmente, pela solubilidade do sal produzido e pela velocidade com que este sal é dissolvido e lixiviado. Assim, a velocidade da degradação será maior em soluções correntes do que em soluções estagnadas. $\mathrm{O}$ aumento da velocidade de deslocamento do agente agressor, de sua temperatura e de sua pressão contribui para o aumento da intensidade do ataque. Pode-se dizer ainda que a velocidade do ataque diminui quando o agregado fica exposto, pois reduz a superfície vulnerável e força o elemento agressor a contornar as partículas do agregado.

Existe uma diferença fundamental entre o ataque por ácidos e o ataque por sulfatos ou álcalis. No primeiro caso, o sistema de poros é destruído como um todo, uma vez que os ácidos reagem com todos os componentes do cimento. Nos demais casos, apenas certos componentes são atacados, sendo a permeabilidade de importância primordial. 
Em casos de ataque leve por ácidos, um nível aceitável de proteção pode ser alcançado mediante adoção das seguintes medidas preventivas:

$\Rightarrow$ Reduzir a permeabilidade do concreto (ver item 3.1). PAULON (1986) recomenda relação água-cimento máxima de 0,45, para estruturas em contato com esgoto doméstico.

$\Rightarrow$ Sempre que possível, minimizar o tempo de exposição do concreto aos ácidos e evitar imersão.

$\Rightarrow$ Promover secagem do concreto antes de expô-lo aos ácidos. A ação do $\mathrm{CO}_{2}$ forma uma película de carbonato de cálcio, obstruindo os poros e reduzindo a permeabilidade da camada superficial.

$\Rightarrow$ Promover cristalização dos poros, mediante tratamentos com gás tetrafluoreto de silício $\left(\mathrm{SiF}_{4}\right)$ no vácuo, vidro líquido (silicato de cálcio) ou fluossilicato de magnésio. Estes agentes fixam a cal livre e proporcionam preenchimento dos poros.

$\Rightarrow$ Promover tratamentos artificiais das superfícies expostas de concreto com alcatrão de carvão, pinturas de borracha e betuminosas, resinas epóxicas e outros agentes. É importante que o revestimento seja aderente ao concreto e, também, resistente ao desgaste por ações mecânicas.

\subsubsection{Ataque por Água Puras}

Consideram-se águas quimicamente puras, entre outras, a água destilada, água de poços em regiões silicosas, águas provenientes de condensação ou degelo e algumas águas de montanha. Essas águas não contêm sais dissolvidos e, portanto, possuem grande capacidade de dissolução, podendo danificar seriamente a pasta de cimento, a partir da lixiviação dos seus constituintes, destruindo, assim, a estrutura dos poros. 
A pasta de cimento contém, aproximadamente, $65 \%$ de cal ( $\mathrm{CaO})$, parte do qual se apresenta livre sob a forma de hidróxido de cálcio $\left(\mathrm{Ca}(\mathrm{OH})_{2}\right)$, altamente solúvel e facilmente lixiviado.

O hidróxido de cálcio é responsável por manter estáveis os silicatos e aluminatos produzidos na hidratação do cimento Portland. Teoricamente, sob um fluxo constante de água, o hidróxido é dissolvido e lixiviado, provocando uma redução da alcalinidade da solução em contato com os citados compostos hidratados, os quais vão se transformando em precipitado de sílica-gel, sem qualidades aglomerantes, nem resistência mecânica.

Este fenômeno, no entanto, limita-se a águas praticamente puras, uma vez que águas que já contêm sais dissolvidos têm sua capacidade de dissolução bastante reduzida. Além disso, para que os danos sejam significativos, o ataque deve ocorrer durante um longo período de tempo, o que o torna pouco comum na prática.

A cal dissolvida e lixiviada sofre carbonatação na superfície de evaporação, pela ação do dióxido de carbono $\left(\mathrm{CO}_{2}\right)$ presente na atmosfera (ver item 3.3.5), resultando em depósitos brancos denominados eflorescências. A cor esbranquiçada, neste caso, deve-se à formação do carbonato de cálcio. A menos do efeito catastrófico da lixiviação sobre o sistema de poros, as eflorescências só prejudicam o concreto no que diz respeito a sua aparência.

Eflorescências também podem ser causadas por uso de agregados não lavados originados de praia. O gesso e os álcalis dos agregados provocam efeitos semelhantes.

Para prevenir contra a agressividade das águas puras, valem as seguintes recomendações:

$\Rightarrow$ Minimizar a permeabilidade do concreto (ver item 3.1).

$\Rightarrow$ Utilizar cimentos pozolânicos ou de alto forno para evitar a dissolução do hidróxido de cálcio. 
$\Rightarrow$ Promover tratamentos superficiais para impedir o acesso da água no concreto.

\subsubsection{Ataque por $\mathrm{CO}_{2}$ Agressivo}

Um dos principais mecanismos condicionantes da corrosão das armaduras em estruturas de concreto armado, juntamente com a penetração de cloretos, é a carbonatação. Este fenômeno ocorre naturalmente, sempre que o concreto é exposto a dióxido de carbono $\left(\mathrm{CO}_{2}\right)$, e tem por conseqüência a redução da alcalinidade da pasta de cimento (que, em condições adequadas de umidade, corresponde a pH entre 12 e 13), responsável, junto com outros fatores, pela proteção das armaduras contra corrosão.

Praticamente todos os constituintes do cimento hidratado são suscetíveis ao ataque por $\mathrm{CO}_{2}$. A carbonatação pode, em alguns casos, ser benéfica, conduzindo a um aumento da resistência, da densidade e da estabilidade volumétrica do concreto. Em outros casos, entretanto, o fenômeno pode resultar em deterioração e redução do $\mathrm{pH}$ para valores inferiores a 9, propiciando a corrosão das armaduras. Dentre os fatores determinantes da intensidade do ataque, destacam-se as condições ambientais e, principalmente, a quantidade de $\mathrm{CO}_{2}$ agressivo.

$\mathrm{O} \mathrm{CO}_{2}$ pode ser encontrado na atmosfera, principalmente em centros urbanos e áreas industrializadas, ou dissolvidos em água, como por exemplo, água do mar e água de chuva ácida que penetra no solo, onde a concentração de $\mathrm{CO}_{2}$ livre pode ser elevada com a decomposição de vegetais. As concentrações de $\mathrm{CO}_{2}$ na atmosfera variam de $0,03 \%$ a $0,05 \%$ em ambientes rurais até $1,2 \%$ em ambientes urbanos com tráfego pesado.

$\mathrm{O} \mathrm{CO}_{2}$ presente na atmosfera penetra no concreto através dos seus poros, por processo de difusão, dissolve-se na fase aquosa dos poros e reage com o hidróxido de cálcio, segundo a equação (3.1). O produto desta reação é um carbonato de cálcio $\left(\mathrm{CaCO}_{3}\right)$, praticamente insolúvel na água, que preenche os poros do concreto, 
aumentando sua resistência e densidade. Esta reação vai ocorrer enquanto houver hidróxido de cálcio disponível. Reações de menor importância ocorrem com outros álcalis $(\mathrm{NaOH}$ e $\mathrm{KOH})$, silicatos e aluminatos do cimento.

$$
\mathrm{Ca}(\mathrm{OH})_{2}+\mathrm{CO}_{2} \rightarrow \mathrm{CaCO}_{3}+\mathrm{H}_{2} \mathrm{O}
$$

Não havendo mais hidróxido de cálcio, o carbonato de cálcio insolúvel, por sua vez, reage com o restante do $\mathrm{CO}_{2}$ dissolvido, segundo a equação (3.2), para formar o bicarbonato de cálcio $\left(\mathrm{Ca}\left(\mathrm{HCO}_{3}\right)_{2}\right)$, que é um sal solúvel. A lixiviação deste sal provoca um aumento da porosidade do concreto, proporcionando condições para outras formas de deterioração, como por exemplo, a ação de sulfatos, ácidos e águas puras. A esse excedente de $\mathrm{CO}_{2}$, capaz de transformar carbonato insolúvel em bicarbonato solúvel, designa-se $\mathrm{CO}_{2}$ agressivo, pois é ele quem vai afetar a durabilidade do concreto.

$$
\mathrm{CaCO}_{3}+\mathrm{CO}_{2}+\mathrm{H}_{2} \mathrm{O} \leftrightarrow \mathrm{Ca}\left(\mathrm{HCO}_{3}\right)_{2}
$$

$\mathrm{O} \mathrm{CO}_{2}$ dissolvido em água, geralmente, apresenta-se na forma de ácido carbônico $\left(\mathrm{H}_{2} \mathrm{CO}_{3}\right)$. Este ácido reage com o hidróxido de cálcio do cimento, segundo os mecanismos ora descritos e representados pelas equações (3.1) e (3.2).

O processo se inicia nas superfícies expostas e vai lentamente evoluindo para o interior da massa de concreto, formando, assim, uma frente de carbonatação. A evolução do ataque depende da umidade relativa do ar, da permeabilidade do concreto e, obviamente, da concentração de $\mathrm{CO}_{2}$.

A umidade relativa do ar é um fator decisivo na velocidade da carbonatação, visto que influi diretamente no grau de saturação dos poros. Conforme dito anteriormente, $\mathrm{o}_{2}$ penetra nos poros por difusão e se dissolve na fase aquosa. Se os poros estiverem saturados de água (por exemplo, durante a cura, em concretos submersos ou em locais onde a umidade é elevada), a difusão terá que se dar em meio aquoso, sendo, portanto, muito mais lenta (cerca de 10.000 vezes) se comparada com a difusão em meio gasoso. Se, por outro lado, a umidade relativa do 
ar for muito baixa, a dissolução, tanto do $\mathrm{CO}_{2}$ como do $\mathrm{Ca}(\mathrm{OH})_{2}$, fica praticamente impedida ou retardada, o mesmo acontecendo com a carbonatação.

As maiores velocidades das frentes de carbonatação ocorrem quando a umidade relativa do ar é mantida dentro de certos limites. Entretanto, não há um consenso entre os diversos pesquisadores sobre os valores desses limites. Normalmente, considera-se que para umidades menores do que $50 \%$ ou maiores do que $95 \%$, os efeitos da carbonatação são desprezíveis.

As recomendações para obtenção de concretos duráveis face à agressividade do $\mathrm{CO}_{2}$ são:

$\Rightarrow$ Minimizar a permeabilidade (ver item 3.1). Convém adotar relação águacimento máxima de 0,45 e teor mínimo de cimento de $350 \mathrm{~kg} / \mathrm{m}^{3}$, segundo PAULON (1986).

$\Rightarrow$ Evitar o uso de cimentos pozolânicos, pois são menos resistentes à ação do $\mathrm{CO}_{2}$. Este fato pode ser explicado pelo conceito de reserva alcalina (KAZMIERCZAK e HELENE, 1993). No cimento Portland comum, devido à maior concentração de $\mathrm{Ca}(\mathrm{OH})_{2}$ na fase aquosa dos poros capilares, a carbonatação é mais lenta, pois o $\mathrm{CO}_{2}$ precisa reagir com todo o $\mathrm{Ca}(\mathrm{OH})_{2}$ presente, para então migrar para regiões não carbonatadas.

$\Rightarrow$ Em caso de concreto armado, adotar um cobrimento adequado, tendo em vista a proteção das armaduras contra a corrosão (ver item 3.7).

$\Rightarrow$ Proteger o concreto mediante cristalização dos poros nas superfícies em contato com o meio agressivo.

$\Rightarrow$ Evitar exposição do concreto ao $\mathrm{CO}_{2}$ durante o processo de endurecimento, visto que pode afetar a resistência ao desgaste e a permeabilidade da superfície de acabamento em lajes. 


\subsubsection{Reações com Agregados}

Assim como a pasta de cimento, alguns agregados também sofrem ações deletérias que podem afetar o desempenho do concreto. Algumas reações químicas dos agregados podem ser benéficas; outras podem resultar em sérios danos ao concreto, devido a expansões internas, acompanhadas por formação de fissuras e perda de resistência.

Inúmeras são as reações químicas com os agregados, dentre as quais as mais importantes e freqüentes são as que envolvem os álcalis do cimento e certas partículas dos agregados. Distinguem-se dois tipos principais de reações: álcali-sílica e álcali-carbonato.

As reações álcali-sílica envolvem os íons $\mathrm{OH}^{-}$associados aos álcalis $\left(\mathrm{Na}_{2} \mathrm{O}\right.$ e $\left.\mathrm{K}_{2} \mathrm{O}\right)$ do cimento ou de outras fontes (águas contendo álcalis, por exemplo) e certos constituintes siliciosos de determinados tipos de agregados.

Embora sejam as mais conhecidas e as que maior atenção têm recebido, ainda existem divergências quanto aos mecanismos que governam as reações álcali-sílica. Sabe-se, entretanto, que essas reações podem resultar em expansões consideráveis, dependendo de certos fatores, dentre os quais: reatividade (presença, tipo e quantidade de sílica) e dimensões dos agregados, concentração de álcalis nos poros, tipo e quantidade de cimento e condições de exposição (umidade e temperatura), principalmente com relação à quantidade de água disponível para as reações.

A sílica pode ser dissolvida em soluções de elevada alcalinidade. Se a superfície dos agregados for suficiente para o processamento das reações (isto é, se os agregados forem suficientemente numerosos ou finos), forma-se um gel álcalisílica sem aumento de volume. Neste caso, as reações têm um efeito favorável e contribuem para aumentar a aderência entre a pasta de cimento e os agregados. Por outro lado, se a quantidade de álcali é grande comparada com a superfície disponível dos agregados, a formação do gel caracteriza-se por um comportamento altamente expansivo, propiciando a degradação do concreto. 
As reações álcali-carbonato, por sua vez, ocorrem entre os álcalis do cimento e certas rochas carbonatadas, podendo provocar expansão e fissuração excessivas. Essas reações ocorrem, geralmente, com certos agregados de calcário dolomítico argiloso. Os mecanismos das reações não estão ainda bem definidos. Porém, sabe-se que são reações bastante diferentes das que ocorrem entre álcalis e sílica. Acredita-se que os calcários existentes no Brasil não causam este tipo de reação.

Os agregados reconhecidamente reativos devem, sempre que possível, ser evitados. Havendo a necessidade de usá-los, deve-se providenciar para que sejam feitos ensaios de determinação do nível de reatividade desses agregados, de modo que possam ser aplicados sem prejuízo para o bom desempenho do concreto em serviço. Todavia, é importante alertar que a forma mais eficiente, segura e econômica de combater os efeitos das reações é evitando o uso de agregados reativos.

Nos casos de uso de agregados reativos com álcalis, recomendam-se ainda os seguintes procedimentos:

$\Rightarrow$ Utilizar cimentos com baixo teor de álcalis. Existe uma recomendação tradicional de limitar o teor máximo de álcalis em $0,6 \%$ de $\mathrm{Na}_{2} \mathrm{O}$ equivalente. Com relação à reação álcali-carbonato, o ACI 201.2R (1992) sugere que este valor seja reduzido para 0,4 a 0,45\%. Entretanto, mesmo com cimentos com baixo teor de álcalis, pode haver migração para as superfícies de evaporação, resultando, nessas regiões, altas concentrações e maiores riscos de deterioração. Portanto, esta medida tomada isoladamente mostra-se insuficiente, devendo ser associada a outras a seguir indicadas.

$\Rightarrow$ Proibir o uso de água do mar e de águas alcalinas na mistura e evitar adições de cloreto de sódio e de potássio.

$\Rightarrow$ Empregar pozolanas e escórias de alto forno, pois reduzem a permeabilidade e a concentração de hidróxido de cálcio. $\mathrm{O}$ teor desses materiais na mistura deve ser determinado através de ensaios. O ACI 201.2R (1992) ressalta que, para reações álcali-carbonato, as 
pozolanas servem apenas como diluentes e não são eficientes para amenizar os efeitos das reações.

$\Rightarrow$ Diluir os agregados reativos, misturando-os com outros não reativos.

$\Rightarrow$ Reduzir o diâmetro nominal máximo do agregado.

\subsection{PROCESSOS FÍSICOS}

Dentre os tipos de deterioração causados por processos físicos, destacam-se o congelamento da água contida nos poros do concreto e a cristalização de sais. $\mathrm{O}$ fenômeno do congelamento no concreto é, obviamente, muito mais freqüente e prejudicial em regiões de clima frio. Por não ser um mecanismo de deterioração típico do Brasil, de clima tropical, será feita apenas uma abordagem superficial, a título de informação para os leitores. Para maiores esclarecimentos, recomenda-se consultar ACI 201.2R (1992), CEB Bulletin d'Information n.182 (1989) e NEVILLE (1982).

\subsubsection{Ciclo Gelo-Degelo}

Nas concretagens em tempo frio, pode ocorrer o congelamento da água do concreto ainda fresco. Se este fenômeno se dá antes do início da pega, os danos se reduzem apenas a um retardamento do processo de endurecimento do concreto. Isto se deve ao fato de que a água de amassamento, necessária às reações de hidratação do cimento, encontra-se congelada. Após o descongelamento, é necessário que o concreto seja revibrado para que ocorram a pega e o endurecimento da massa sem prejuízo para a resistência do concreto.

Quando o congelamento se dá após a pega, os danos podem ser irrecuperáveis se o concreto, ainda muito jovem, não tiver atingido uma certa resistência mínima. Infelizmente, ainda não se dispõe de dados suficientes para fixar o valor desta resistência. $\mathrm{Na}$ falta de maiores informações, valem como referência os valores da 
Tabela 7.9 de NEVILLE (1982), que fornece a idade mínima do concreto, em função do tipo de cimento empregado, da relação água-cimento e da temperatura da cura.

Para melhor entender o mecanismo relativamente complexo de deterioração desencadeado a partir do congelamento da água no concreto endurecido, é preciso conhecer os principais processos físicos envolvidos, os quais são descritos nas linhas que seguem.

A transição da água do estado líquido para o sólido caracteriza-se por um acréscimo de volume de, aproximadamente, 9\%. Para que esta expansão seja absorvida sem danos significativos, é necessária a presença de uma certa quantidade de poros contendo ar, ou seja, não totalmente preenchidos por água. Pode-se dizer que existe um nível crítico de saturação, acima do qual os efeitos do congelamento são bastante nocivos ao concreto. Este nível crítico depende de diversos fatores, dentre eles: distribuição do tamanho dos poros, condições ambientais, velocidade de resfriamento e freqüência do ciclo gelo-degelo, secagem entre os ciclos e idade do concreto.

A temperatura de congelamento da água varia com o tamanho dos poros, sendo tanto menor quanto menor for este tamanho. Segundo LITVAN (1972) ${ }^{6}$ apud ACI 201.2R (1992), a água adsorvida ou contida nos poros menores não congela devido à interação com a superfície dos poros. Esta água tende a se deslocar para regiões onde possa congelar. Assim, uma parte dela segue em direção à superfície externa, por onde pode evaporar, desde que haja condições ambientais propícias (umidade relativa do ar). A outra parte da água migra para os poros maiores, onde inicialmente ocorre a formação de gelo, o qual vai, gradativamente, aumentando seu volume, até preencher completamente os poros, desenvolvendo tensões capazes de danificar a pasta de cimento.

O deslocamento da água em direção aos poros maiores é, até certo ponto, irreversível, de modo que a quantidade de água nestes poros aumenta à medida que cresce o número de ciclos gelo-degelo. Em certos casos, os danos causados por

\footnotetext{
${ }^{6}$ LITVAN, G. G. (1972). Phase transitions of adsorbates: IV, mechanism of frost action in hardened
} concrete paste. Journal of the Americam Ceramic Society, v.55, n.1, p.38-42. 
congelamento só se tornam graves após um certo número de ciclos, se não houver secagem, mesmo que parcial, entre os ciclos. Esta secagem promove espaço dentro dos poros para absorver uma nova expansão.

Do exposto, observa-se que a deterioração decorre, principalmente, da incapacidade do concreto de absorver o acréscimo de volume que a água sofre ao congelar. Esta incapacidade, por sua vez, é conseqüência da impossibilidade de redistribuição da água na massa do concreto durante o fenômeno, seja pelo alto grau de saturação do concreto, pelas dificuldades impostas por sua estrutura de poros ou, ainda, pela velocidade elevada de resfriamento.

A utilização de ar incorporado ao concreto tem se mostrado bastante eficaz no combate aos danos causados pelos ciclos gelo-degelo. Chama-se ar incorporado, aquele que é introduzido intencional e artificialmente no concreto, por meio de um agente apropriado. $\mathrm{O}$ ar incorporado produz cavidades descontínuas na pasta de cimento, de modo que não se formam canais para a passagem de água e, portanto, não aumenta a permeabilidade do concreto.

Em regiões frias, é comum a utilização de agentes de descongelamento sobre superfícies cobertas de gelo, tais como pavimentos de rodovias. A aplicação desses agentes, normalmente constituídos por sais (cloretos de sódio e de cálcio), pode trazer conseqüências indesejáveis, não só do ponto de vista do ataque do concreto pelo congelamento, mas também com relação à corrosão das armaduras, conforme será visto no item 3.7 .

A maior concentração de sais nas superfícies onde são aplicados, em relação às regiões internas no concreto, provoca o surgimento de uma pressão osmótica, que faz com que a água se desloque em direção àquelas superfícies. Este aumento no grau de saturação representa a principal causa dos efeitos nocivos que os sais ocasionam.

A pasta de cimento e os agregados apresentam comportamentos distintos com relação ao ataque por congelamento, sendo a vulnerabilidade da pasta muito maior. Isto se deve ao fato de que, dificilmente, os agregados atingem a saturação quando em serviço, a menos que já estejam saturados no momento da confecção do concreto. 
A resistência do agregado aos efeitos do congelamento é inversamente proporcional ao seu tamanho. Assim, agregados miúdos têm, em geral, grande resistência ao ataque por congelamento. Os agregados graúdos com poros de tamanho médio são os mais críticos. Quando os poros são muito grandes, raramente estão totalmente preenchidos por água. Por outro lado, nos poros pequenos, a água não congela pelas razões anteriormente apresentadas.

Com vistas a garantir adequada resistência do concreto aos efeitos do ciclo gelo-degelo, recomendam-se as seguintes medidas práticas:

$\Rightarrow$ Utilizar concretos com aditivos incorporadores de ar em proporções adequadas, especialmente se for previsto o uso de sais para degelo. O teor recomendado de ar no concreto depende do tamanho do agregado e da severidade da exposição (vale como referência, por exemplo, a Tabela 1.4.3 do ACI 201.2R, 1992).

$\Rightarrow$ Ainda com relação à composição do concreto, deve-se adotar relação águacimento reduzida e um certo teor mínimo de cimento na mistura, a fim de garantir um concreto denso e com poros de tamanho reduzido. O ACI 201.2R (1992) recomenda relação a/c máxima de 0,45 para estruturas esbeltas ou expostas aos sais de degelo e de 0,50 nos demais casos. Além da dosagem adequada, é essencial que a execução seja cuidadosa, principalmente no que se refere ao adensamento e à cura.

$\Rightarrow$ Evitar submeter o concreto muito jovem aos efeitos do congelamento, uma vez que, possuindo maior quantidade de água nos poros (água adicionada à mistura e ainda não evaporada), são mais sensíveis aos efeitos deste fenômeno. O ACI 201.2R (1992) recomenda resistência mínima de $28 \mathrm{MPa}$ em condições severas de exposição e de $21 \mathrm{MPa}$ em condições moderadas.

$\Rightarrow$ Após a cura, com duração adequada, é aconselhável promover uma secagem do concreto, ainda que parcial, antes de submetê-lo ao congelamento. Adicionalmente, sempre que possível, deve-se propiciar condições para que haja evaporação da água durante o congelamento. 
$\Rightarrow$ Submeter os agregados a ensaios de laboratório sempre que houver dúvidas quanto à sua resistência ao congelamento da água. É preferível que os testes sejam realizados em concretos feitos com o agregado em questão e não apenas nos agregados isoladamente.

$\Rightarrow \mathrm{O}$ projeto deve prever a drenagem da estrutura para evitar que a água fique empoçada por muito tempo. Além disso, a fissuração deve ser controlada a fim de dificultar a penetração da água no concreto, o que causaria aumento do grau de saturação.

$\Rightarrow$ Nas lajes de pavimentos sujeitos a ação de sais de degelo, deve-se evitar o acabamento excessivo da superfície e a adição de água para ajudar nesta tarefa. Tais procedimentos podem provocar exsudação excessiva e prejudicar a resistência do concreto superficial aos agentes de degelo.

\subsubsection{Cristalização de Sais}

A cristalização de sais já foi brevemente comentada no item 3.3.2. Águas salinas (como, por exemplo, a água do mar) podem penetrar num concreto com alto índice de permeabilidade, a partir de sua superfície, e percolar através dos poros e condutos capilares que compõem a estrutura interna do concreto endurecido. Havendo uma superfície externa exposta ao ar, criam-se condições propícias para que esta água evapore, deixando os sais no concreto.

Estas substâncias cristalizam-se num fenômeno caracterizado por aumento de volume. Além da desagregação do concreto superficial, a aparência do concreto fica também comprometida pela formação de eflorescências. Para prevenir contra este tipo de deterioração, deve-se limitar a permeabilidade do concreto (ver item 3.1). 


\subsection{PROCESSOS MECÂNICOS}

As estruturas de concreto podem ser deterioradas também por processos mecânicos, tais como, a ação de cargas excessivas, vibrações e erosão.

As cargas excessivas, assim como vibrações não previstas no projeto, podem provocar fissuração excessiva e abrir caminho para que outras formas de deterioração se instalem. Os projetistas devem sempre evidenciar as cargas adotadas no dimensionamento das estruturas e os usuários, por sua vez, devem obedecer às condições especificadas no projeto.

As vibrações podem ser decorrentes de detonações ou de operações de equipamentos. As vibrações por detonação se devem à propagação de ondas elásticas através da rocha. Ao atingirem as fundações de uma estrutura de concreto, essas ondas podem causar diversos tipos de deformações, com danos devidos a tração, cisalhamento ou flexão. As vibrações por equipamentos merecem destaque, principalmente, quando possuem caráter permanente. A intensidade da deterioração causada por vibrações depende da amplitude das vibrações, da distância da fonte geradora e da idade do concreto. O projeto das estruturas deve prever este tipo de ação, de modo a garantir um nível satisfatório de segurança e de durabilidade.

A erosão do concreto consiste no desgaste da sua camada superficial por processos de atritamento, arranhamento ou percussão, ou ainda por águas em alta velocidade. As principais causas da erosão são a abrasão e a cavitação.

\subsubsection{Abrasão}

A resistência do concreto à abrasão é definida como a capacidade de sua camada superficial resistir ao desgaste por atritamento, arranhamento ou percussão.

O desgaste de superfícies de concreto por abrasão pode ser causado por tráfego pesado e por impacto ou deslizamento de cargas (movimento de equipamentos, por exemplo), materiais de enchimento e partículas sólidas transportadas pelo vento ou pela água. Essas ações podem ocorrer, por exemplo, em 
pisos industriais, pavimentos, silos, canais, pilares de pontes, barragens e estruturas hidráulicas, em geral.

A velocidade da erosão depende da qualidade do concreto da superfície e, no caso de águas correntes, da quantidade, forma, tamanho e dureza das partículas transportadas, bem como da sua velocidade.

A resistência do concreto à abrasão é um fenômeno progressivo. Inicialmente, ela depende fundamentalmente da resistência da superfície submetida ao desgaste, que pode ser melhorada mediante revestimentos, técnicas de acabamento e procedimentos de cura específicos. À medida que a pasta de cimento é desgastada e os agregados ficam expostos, a resistência passa a ser função da aderência entre a pasta e os agregados e da dureza dos agregados, os quais são mais resistentes à abrasão do que a pasta de cimento.

Ensaios de laboratório e experiências de campo revelam que o principal fator interveniente na resistência do concreto à abrasão é a sua resistência à compressão, sendo estes parâmetros diretamente proporcionais. Recomenda-se que os concretos sujeitos a intensa deterioração mecânica tenham resistência característica à compressão, pelo menos, igual a $40 \mathrm{MPa}$ e slump máximo de $9 \mathrm{~cm}$, segundo a revisão da NB 1 (1994). Um critério mais refinado pode ser visto no ACI 302.1R (1989) ${ }^{7}$ apud ACI 201.2R (1992), que fornece uma classificação dos pisos sujeitos a desgaste por abrasão, recomendando slump máximo e resistência mínima à compressão para cada classe.

A aceitação do concreto, no entanto, não deve se basear unicamente nos ensaios de corpos-de-prova cilíndricos à compressão. É essencial que seja realizada uma inspeção cuidadosa da superfície de acabamento para verificar a qualidade do concreto, visto que é o concreto na superfície e próximo a ela que, de fato, influencia na resistência do concreto à abrasão. A textura da superfície deve ser bem compacta e sem presença de nata excedente de cimento.

\footnotetext{
${ }^{7}$ AMERICAN CONCRETE INSTITUTE (1989). ACI 302.1R: Guide for concrete floor and slab constructions. Detroit, Michigan.
} 
Assim, medidas devem ser tomadas para garantir a qualidade deste concreto superficial, dentre elas, evitar segregações e exsudação excessivas, controlar a duração das operações de acabamento, proibir a adição de água para auxiliar o acabamento (de modo a evitar aumento da relação água-cimento na superfície), retirar o excesso de água na superfície antes do acabamento e promover cura apropriada (em geral, mais prolongada do que a usual), para garantir um certo grau de hidratação do cimento nas camadas externas e reduzir a porosidade. A utilização de revestimentos absorventes nas fôrmas contribui para reduzir a relação água-cimento no concreto da superfície, aumentando sua resistência.

A composição da mistura também influencia na resistência do concreto à abrasão. Concretos com agregados maiores, mais densos e de maior dureza sofrem menor desgaste por abrasão. No entanto, em certas circunstâncias, os agregados menores conduzem a uma erosão mais uniforme da superfície, o que pode ser vantajoso. O aumento do teor de cimento, por sua vez, gera uma diminuição da resistência à abrasão, o que se explica pela maior formação de nata na superfície. NEVILLE (1982) revela que na Alemanha, por exemplo, é comum especificar teor máximo de cimento de $400 \mathrm{~kg} / \mathrm{m}^{3}$ para tamanho máximo do agregado de $16 \mathrm{~mm}$ e, alternativamente, $350 \mathrm{~kg} / \mathrm{m}^{3}$ de cimento para agregado de $32 \mathrm{~mm}$.

Mesmo os melhores concretos raramente podem suportar abrasão durante períodos prolongados.

\subsubsection{Cavitação}

Além da erosão provocada pelas partículas sólidas carregadas pela água, outro tipo de deterioração, caracterizada pela formação de pequenas cavidades, pode ser verificada em concretos submetidos a fluxos de água em alta velocidade. 
Quando a pressão estática da água corrente, em alguns pontos, se torna menor do que a pressão do vapor à temperatura ambiente, formam-se bolhas de vapor, que se deslocam com a correnteza. Em regiões de alta pressão, ocorre a condensação do vapor e as bolhas sofrem uma redução brusca de tamanho, causando grande impacto. Essa redução de tamanho implica em entrada de água, com grande velocidade, no espaço antes ocupado pelo vapor, acarretando o surgimento de uma pressão extremamente elevada, durante intervalos de tempo muito curtos. É a repetição desses impactos numa mesma região da superfície do concreto que provoca $o$ aparecimento de cavidades. O fenômeno ora descrito denomina-se cavitação.

A queda de pressão para valores abaixo da atmosférica pode ser causada por sifonamento, efeito de inércia no interior de uma curva ou presença de irregularidades na superfície. Nestas situações, pode haver um descolamento do fluxo de água da superfície de contato, propiciando a cavitação. Danos provocados por cavitação têm sido observados, muito freqüentemente, em canais abertos (para velocidades acima de $12 \mathrm{~m} / \mathrm{s}$ ), condutos fechados e vertedouros de barragens.

Contrariamente à textura lisa das superfícies de concreto danificadas por abrasão causada por partículas sólidas carreadas pela água, a superfície de um concreto atingido por cavitação se mostra irregular, riscada e cheia de cavidades.

Para obtenção de concretos resistentes à cavitação valem as mesmas observações feitas anteriormente para concretos resistentes à abrasão, exceto no que se refere às especificações dos agregados.

A cavitação tende a remover as partículas maiores dos agregados. Desta forma, muito mais importante do que a dureza dos agregados (como ocorre em casos de abrasão) é a sua aderência com a pasta de cimento. Por esse motivo, deve ser dada preferência à utilização de agregados de diâmetros menores (tamanho máximo de $20 \mathrm{~mm}$, segundo NEVILLE, 1982), os quais são mais dificilmente arrancados pelas forças oriundas da cavitação. 
Concretos de alta resistência, com fibras ou com polímeros podem ser usados para aumentar a resistência do concreto à cavitação. Podem também ser utilizados revestimentos resilientes, os quais reduzem as tensões a níveis que o concreto pode suportar. Alguns revestimentos à base de neoprene e poliuretano, por exemplo, dão resultados satisfatórios, desde que sejam aderentes ao concreto. A execução de uma camada fina de argamassa de epóxi é uma outra alternativa, embora mais dispendiosa.

Nem mesmo os melhores concretos podem resistir às ações da cavitação por tempo indeterminado. Os efeitos da cavitação, entretanto, podem ser atenuados por meio de superfícies lisas, bem acabadas, isentas de irregularidades (tais como depressões, saliências, juntas e desalinhamentos) e de mudanças bruscas de inclinação ou de curvatura, que tendem a provocar descolamento do fluxo d'água. Devem ser evitados também aumentos localizados de velocidade deste fluxo.

\subsection{PROCESSOS BIOLÓGICOS}

Além dos mecanismos de deterioração anteriormente descritos, causados por processos químicos, físicos ou mecânicos, o concreto pode ainda sofrer um outro tipo de agressão, representado pelo ataque por agentes biológicos.

Uma forma bastante comum de ataque biológico é aquela que ocorre em tubulações de esgoto. Na verdade, as bactérias presentes nestes locais não agridem o concreto diretamente, mas o ácido sulfúrico resultante das reações que estas bactérias desencadeiam é altamente nocivo à integridade da pasta de cimento (ver item 3.3.3).

Em superfícies rugosas de concretos com alta porosidade, pode ocorrer a proliferação de parasitas de origem animal ou vegetal, tais como algas, moluscos e outros organismos microscópicos. A maior proliferação de parasitas é observada nos locais onde há grande quantidade de nutrientes, como em regiões próximas a saídas de esgoto. O resultado desta proliferação é o aumento do grau de saturação nas regiões afetadas, devido à retenção de maior quantidade de água. A penetração desses 
organismos no concreto gera forças de fendilhamento capazes de provocar físsuração. Raízes de plantas têm efeito semelhante e podem ser igualmente prejudiciais.

Além da deterioração mecânica ora citada, existe ainda a possibilidade de ataque químico à pasta de cimento pela ação dos ácidos orgânicos e dos sulfatos formados durante o processo de decomposição. O aumento da umidade do concreto superficial e a presença de fissuras propiciam condições favoráveis para que outras formas mais severas de deterioração se instalem.

Em regiões costeiras, a probabilidade de desenvolvimento de microrganismos nas superfícies é maior nas zonas situadas abaixo do nível de maré alta. Na zona submersa o crescimento de vegetação nas superfícies do concreto pode ter um efeito favorável em relação à sua proteção. As plantas consomem o oxigênio antes que ele penetre no concreto por difusão, inibindo assim o processo de corrosão das armaduras e, por conseguinte, aumentando a durabilidade da estrutura.

A deterioração do concreto por ataque biológico não é um problema comum. À exceção do que ocorre nos esgotos, em geral, este tipo de ataque não causa danos significativos. Para prevenir contra o crescimento de parasitas nas superfícies expostas, PAULON (1986) sugere a introdução de sais de cobre à massa do concreto. Em casos de reparo, ainda segundo este autor, deve-se providenciar, inicialmente, a retirada dos vegetais por meio de jateamento e, posteriormente, fazer o tratamento superficial do concreto com argamassa contendo sais de cobre.

\subsection{CORROSÃO DAS ARMADURAS}

A durabilidade das estruturas de concreto armado depende, igualmente, da durabilidade do concreto e do aço que compõe as armaduras. Nos itens anteriores foram apresentados e discutidos os principais agentes agressivos ao concreto, os quais atingem indiretamente a integridade das armaduras, pois prejudicam a qualidade do concreto que lhes serve de proteção. 
Com relação à armadura, o principal mecanismo de deterioração consiste na corrosão. A degradação do concreto armado por corrosão de suas armaduras é um dos problemas mais graves e mais comuns nas estruturas. Conhecer e combater as condições necessárias à ocorrência deste fenômeno são tarefas essenciais quando se busca a durabilidade das estruturas de concreto armado, evitando-se custos com reparos, geralmente, bastante altos.

\subsubsection{Condições Essenciais para a Corrosão}

Em condições normais, o concreto funciona como uma proteção natural do aço contra a corrosão, graças à alta alcalinidade ( $\mathrm{pH}$ em torno de 12,5) da pasta de cimento que envolve as barras da armadura. Em meio a este pH elevado, dá-se a formação de uma camada microscópica de óxidos sobre a superfície do aço, a qual denomina-se camada passivante, pois impede a dissolução do ferro.

Enquanto a camada passivante estiver intacta, o aço estará protegido contra a corrosão. No entanto, a redução da alcalinidade da pasta de cimento para valores abaixo de 9 e a presença de íons cloreto em concentrações acima de certos valores limites $(0,2 \%$ em relação ao cimento, em peso, segundo o ACI 201.2R, 1992) podem provocar a destruição desta camada protetora em pontos localizados ou em áreas maiores, tornando possível a instalação do processo de corrosão, desde que haja uma certa quantidade de umidade e de oxigênio disponível.

A redução da alcalinidade do meio pode ser ocasionada pela carbonatação (ver item 3.3.5) ou pela lixiviação dos álcalis contidos nos poros do concreto (ver item 3.3.4). Na prática, a lixiviação se dá mais intensamente próximo a juntas mal executadas, em regiões fissuradas e onde o concreto apresenta alta permeabilidade decorrente, por exemplo, de má execução.

Os íons cloreto, provenientes da água do mar ou dos sais de degelo, podem penetrar no concreto por processo de difusão, através dos poros total ou parcialmente preenchidos por água. Uma certa quantidade desses íons encontra-se quimicamente combinada com o aluminato tricálcico, um dos componentes do cimento Portland, 
formando um cloro-aluminato hidratado. Com relação à corrosão das armaduras, o que de fato importa é a quantidade de cloretos livres. Entretanto, vale ressaltar que após carbonatação, uma parte dos íons cloreto combinados são liberados, elevando, assim, a concentração de cloretos livres na água contida nos poros do concreto e, por conseqüência, aumentando consideravelmente os riscos de corrosão.

Quando o concreto é exposto a ciclos de molhagem e secagem por águas contendo cloretos, como ocorre nas zonas atmosféricas de regiões costeiras e nas zonas de respingo de maré (ver item 3.3.2), é possível um aumento considerável na concentração de íons cloreto nos poros do concreto. Os cloretos penetram no concreto junto com a água durante a fase de molhagem do ciclo e lá permanecem na fase de secagem, quando apenas a água é evaporada.

Da mesma forma como ocorre na carbonatação (penetração de $\mathrm{CO}_{2}$ ), a penetração de íons cloreto $\left(\mathrm{C} \ell^{-}\right)$se inicia na superfície e vai lentamente progredindo para o interior da massa de concreto, de modo que a concentração de gás carbônico e de cloretos diminui com a distância em relação à superfície externa do concreto e aumenta com o tempo.

Com vistas à proteção das armaduras contra a corrosão, torna-se imprescindível providenciar para que a profundidade de carbonatação e de penetração de cloretos seja tal que não atinja os locais onde as armaduras estão dispostas, ou seja, é necessário que tais profundidades sejam inferiores ao valor do cobrimento das armaduras. Desta forma, adotando-se um cobrimento adequado e garantindo a qualidade deste cobrimento em termos de baixa permeabilidade, apenas o concreto superficial será atacado e as armaduras estarão protegidas.

Obviamente nos concretos fissurados, o $\mathrm{CO}_{2}$ e o $\mathrm{C} \ell^{-}$conseguem penetrar mais rapidamente, sendo o tempo para despassivação dependente da abertura das fissuras. Entretanto, quando esta abertura se limita a $0,4 \mathrm{~mm}$ na superfície, os produtos da carbonatação e a própria ferrugem, que, por ventura, já tenha se formado, acabam por preencher a fissura, impedindo que a deterioração prossiga. 


\subsubsection{O Processo da Corrosão e seus Efeitos}

A corrosão do aço no concreto, geralmente, é um fenômeno eletroquímico, que pode ser, simplificadamente, separado em dois processos básicos: o processo anódico e o processo catódico. O processo anódico caracteriza-se pela dissolução do ferro, com liberação de elétrons e formação de íons de ferro (expressão 3.3). No processo catódico, o excedente de elétrons no aço combina-se com água e oxigênio, liberando íons hidróxidos (expressão 3.4).

$$
\begin{aligned}
& \mathrm{Fe} \rightarrow \mathrm{Fe}^{++}+2 \mathrm{e}^{-} \\
& 2 \mathrm{e}^{-}+\frac{1}{2} \mathrm{O}_{2}+\mathrm{H}_{2} \mathrm{O} \rightarrow 2(\mathrm{OH})^{-}
\end{aligned}
$$

Na presença de oxigênio disponível, a partir dos íons de ferro, forma-se a ferrugem $\left(\mathrm{Fe}_{2} \mathrm{O}_{3}\right)$. A água não participa diretamente da formação da ferrugem, porém é necessária para que o processo eletrolítico se desenvolva. Os íons cloretos funcionam como catalisadores, acelerando a dissolução do ferro.

Com base na descrição sucintamente apresentada, pode-se notar que, em concretos secos (umidade relativa do ar abaixo de 60\%), sendo o processo eletrolítico impedido pela insuficiência de água, não haverá corrosão significativa. Por outro lado, em concretos saturados, a corrosão é retardada pela pouca disponibilidade de oxigênio, uma vez que a difusão deste elemento em meio aquoso é bastante lenta. Em ambos os casos, a corrosão estará impedida mesmo se a camada passivante tiver sido destruída.

Os maiores danos provocados por corrosão são verificados em estruturas sujeitas a ciclos de molhagem e secagem, pelas razões já mencionadas anteriormente. Deve-se atentar também para as situações em que o concreto encontra-se apenas parcialmente saturado ou submerso. Neste casos, criam-se zonas distintas onde ocorrem os processos anódico e catódico. Na região submersa, ocorre o processo anódico devido à penetração de $\mathrm{C} \ell^{-}$. $\mathrm{O}$ concreto molhado funciona como um 
conector eletrolítico que conduz os elétrons para a região não submersa do concreto, onde, havendo a possibilidade de difusão de $\mathrm{O}_{2}$, ocorre a formação da ferrugem.

Um dos principais efeitos da corrosão consiste na redução da seção transversal das armaduras, tendo como conseqüência uma perda da capacidade de carga. Porém muito mais afetadas são a ductilidade do aço e a sua resistência à fadiga, que ficam seriamente comprometidas mesmo para pequenas reduções da seção transversal.

Um outro efeito bastante nocivo da corrosão das armaduras é devido ao caráter expansivo das reações envolvidas no processo. Dependendo da disponibilidade de água no momento da formação da ferrugem, seu volume pode alcançar até mais do que 6 vezes o volume do aço. Esta expansão é responsável por gerar forças de fendilhamento, capazes de provocar a fissuração e o destacamento do concreto do cobrimento. Esta situação pode levar à ruptura frágil se, por exemplo, ocorrerem fissuras ao longo das barras, em regiões próximas às ancoragens.

Em casos de baixa disponibilidade de oxigênio, a expansão observada na formação da ferrugem é pequena. Este tipo de corrosão pode prosseguir lentamente e, em determinadas circunstâncias, os produtos da ferrugem podem difundir pelos vazios e poros do concreto, sem causar fissuração. Nestes casos, felizmente raros, pode-se desenvolver grave corrosão sem que isto seja percebido externamente e, por conseguinte, uma ruptura frágil e repentina pode ocorrer.

\subsubsection{Principais Parâmetros Envolvidos e Recomendações}

O fenômeno da corrosão é, basicamente, controlado por processos de difusão. A carbonatação ocorre por difusão do $\mathrm{CO}_{2}$ pelos poros preenchidos por ar. A penetração de cloretos se dá por difusão de $\mathrm{C} \ell^{-}$em meio aquoso. $\mathrm{E}$, finalmente, a formação da ferrugem só é possível na presença de $\mathrm{O}_{2}$, que atravessa os poros de ar do concreto por difusão. 
Portanto, os principais parâmetros controladores da corrosão do aço no concreto são aqueles relacionados com a maior ou menor facilidade com que a difusão ocorre. Assim, é de significativa importância a qualidade do concreto em termos de sua permeabilidade, principalmente nas camadas superficiais.

Na busca pela prevenção de problemas relacionados à corrosão de armaduras, valem as seguintes recomendações e observações:

$\Rightarrow$ Adotar cobrimentos adequados para as armaduras, levando em conta dois aspectos de extrema relevância: a espessura e a qualidade do concreto deste cobrimento. Maiores informações podem ser encontradas no item 4.4.3.

$\Rightarrow$ Minimizar a permeabilidade do concreto (ver item 3.1). A relação águacimento não deve exceder 0,50. Este limite deve ser reduzido a 0,40 para estruturas em ambientes especialmente agressivos, como as situadas em zonas costeiras ou em contato com soluções de cloreto de outras fontes, como por exemplo, os sais de degelo. A permeabilidade cresce consideravelmente a partir de valores de a/c acima de 0,6. O teor de cimento não deve ser menor do que $300 \mathrm{~kg} / \mathrm{m}^{3}$.

$\Rightarrow$ A utilização de cimentos com adições de pozolanas e escórias de alto forno é benéfica no que diz respeito à redução da permeabilidade do concreto. Entretanto, vale lembrar que as escórias podem apresentar um teor significativo de cloretos, o que não é desejável. Além disso, deve-se ressaltar que estes cimentos são mais sensíveis aos efeitos da cura do que os cimentos comuns e, portanto, só darão bons resultados se o concreto for devidamente curado antes de exposto às condições ambientais.

$\Rightarrow$ Evitar, na confecção do concreto, o uso de componentes contendo cloretos, tais como certos tipos de aditivos à base de cloretos e alguns agregados, como os provenientes de ambientes marinhos ou de solos ricos em cloretos. 
$\Rightarrow$ Seguindo recomendações do ACI 201.2R (1992), empregar cimentos com teor mínimo de $5 \%$ de $\mathrm{C}_{3} \mathrm{~A}$ (aluminato tricálcico), visto que este componente do cimento Portland é responsável pela fixação de parte dos íons cloretos presentes nos poros do concreto.

\subsection{AÇÃO DE ALTAS TEMPERATURAS}

A resistência do concreto ao fogo é um tema bastante amplo que, por si só, justificaria a elaboração de um trabalho exclusivamente para tratar do assunto. No entanto, tendo em vista o objetivo pretendido, neste capítulo, de fornecer informações básicas sobre os principais mecanismos de deterioração do concreto, apresenta-se um panorama geral das principais características do ataque do concreto pelo fogo.

A resistência do concreto ao fogo depende, não só da temperatura a que é submetido, como também do tempo de exposição. Na prática, o que de fato interessa não é se o concreto é resistente ou não ao fogo, e sim o período de tempo durante o qual ele é capaz de sofrer esta ação sem apresentar danos significativos.

Em linhas gerais, pode-se dizer que o concreto tem bom comportamento quando exposto ao fogo, sendo capaz de suportar temperaturas elevadas durante um período de tempo relativamente grande, com desempenho satisfatório. A exposição contínua a altas temperaturas resulta em queda da resistência e do módulo de elasticidade.

O fogo origina gradientes de temperatura elevados e, em conseqüência, as camadas da superfície quente tendem a se separar, em lascas, do interior mais frio das peças de concreto. Este gradiente de temperatura entre a superfície e o interior provoca fissuras no concreto, principalmente, nas regiões das juntas, nos locais onde houve mal adensamento e também nos planos das barras das armaduras. 
Um dos critérios fundamentais para análise de desempenho consiste na resistência à transferência de calor, especialmente, tendo-se em vista que o concreto é um material de proteção do aço que compõe as armaduras. De fato, a resistência do concreto ao fogo está diretamente relacionada com a sua condutividade térmica, propriedade que representa a capacidade do material de conduzir calor. Assim, quanto maior o tempo necessário para distribuir o calor na massa do concreto, maior será o período de resistência ao fogo. Neste contexto, destaca-se ainda a participação das armaduras que, quando expostas, passam a conduzir o calor, acelerando a sua ação.

$\mathrm{Na}$ avaliação da condutividade térmica, além da composição, há que se considerar o grau de saturação do concreto, visto que a condutividade térmica do ar é menor do que a da água. Assim, os concretos leves têm menor condutividade térmica do que os concretos comuns e, por isso, são mais resistentes ao fogo. Vale ressaltar ainda que a condutividade térmica da água é bem menor do que a da pasta de cimento. Portanto, quanto menor o teor de água na mistura, maior será a condutividade térmica do concreto endurecido. Concretos mais densos, com maiores teores de cimento, são também mais condutores de calor e, por conseguinte, menos resistentes ao fogo.

Pelas razões explicitadas no parágrafo anterior, conclui-se que a perda de resistência em temperaturas elevadas é maior nos concretos saturados do que nos secos. Em geral, o teor de umidade do concreto é o parâmetro que mais influencia no seu comportamento estrutural em temperaturas elevadas. A umidade excessiva no momento da exposição ao fogo é a causa principal da desagregação.

Para temperaturas a partir de $150^{\circ} \mathrm{C}$, observa-se perda de resistência do concreto à tração, devido à desidratação do gel de cimento e do aumento da microfissuração. A resistência do concreto à compressão não é afetada significativamente até cerca de $250^{\circ} \mathrm{C}$, porém, a partir de $300^{\circ} \mathrm{C}$, sofre uma redução brusca. Segundo NEVILLE (1982), se a temperatura se mantiver elevada por um período curto (ex.: uma hora), pode ocorrer uma recuperação lenta da resistência. 
Em casos de incêndios, a situação se torna crítica quando a temperatura atinge $600^{\circ} \mathrm{C}$. A partir deste estágio, inicia-se uma degradação progressiva do concreto, partindo da superfície e se propagando para o interior da massa. Esta degradação é provocada pela desidratação do gel de cimento e por transformações que ocorrem na sua composição química. Além disso, temperaturas elevadas produzem transformações também nos agregados, provocando aumento do seu volume. Os agregados silicosos são mais sensíveis ao fogo do que os calcários e os leves.

Um outro aspecto de grande relevância refere-se ao comportamento das armaduras em situações de incêndios, fator que condiciona o desempenho do concreto armado quando atacado pelo fogo. $\mathrm{O}$ concreto e o aço reagem de formas distintas à elevação de temperatura. Os aços empregados em concreto armado não sofrem alterações para temperaturas entre $30^{\circ} \mathrm{C}$ e $430^{\circ} \mathrm{C}$. No entanto a partir de $430^{\circ} \mathrm{C}$, ocorre uma queda brusca de resistência, sendo que a $600^{\circ} \mathrm{C}$ observa-se perda de cerca de metade do limite de escoamento.

Vale ressaltar que as armaduras, além de contribuírem para propagação do calor, aumentam consideravelmente de volume quando expostas a temperaturas extremas, conduzindo ao colapso do concreto que as envolve.

A elevação da temperatura também afeta, desfavoravelmente, o módulo de elasticidade do concreto. A redução deste módulo é de grande importância, principalmente, para estruturas esbeltas, como as lajes, onde, devido à pequena espessura, praticamente toda a peça fica submetida a altas temperaturas. Nestes casos, mesmo que não haja destruição da peça, as flechas aumentam consideravelmente, comprometendo o bom desempenho da estrutura em serviço.

As recomendações para que o concreto resista a elevadas temperaturas, sem apresentar degradação, são a seguir apresentadas:

$\Rightarrow$ Utilizar cimentos aluminosos, com porcentagens de alumina proporcionais à temperatura a que o concreto será submetido. 
$\Rightarrow$ Evitar o uso de agregados contendo sílica, dando preferência aos calcários ou escórias de alto forno, assim como também aos agregados leves, como a argila expandida.

$\Rightarrow$ Adotar o menor teor de cimento e a maior relação água-cimento possíveis.

$\Rightarrow$ Com relação às armaduras, no caso de concreto armado, dar preferência aos aços tipo A (recozidos), empregar barras de diâmetro reduzido e adotar cobrimento mínimo de $30 \mathrm{~mm}$. 


\section{CRITÉRIOS DE PROJETO PARA DURABILIDADE}

Quando se objetiva a qualidade das estruturas, é imprescindível a adoção de medidas apropriadas que garantam a sua durabilidade. Muitas destas medidas constituem critérios a serem observados ainda na fase de projeto, alguns dos quais serão abordados neste capítulo, tendo como base, a fundamentação teórica apresentada no capítulo anterior.

Os códigos e as normas técnicas de projeto mais atualizadas tratam de forma mais aprofundada a questão da durabilidade, propondo critérios de projeto que visam assegurar um desempenho satisfatório das estruturas durante todo o tempo previsto de uso. Constituem exemplos o CEB-FIP Model Code 1990 (1993) e o Eurocode 2 (1992).

A Norma Brasileira NBR 6118 (1978), em vigor, mostra-se deficiente neste aspecto, tratando de forma bastante superficial o problema da durabilidade das estruturas, sendo omissa em relação a muitos pontos. Esta deficiência, entretanto, parece estar sendo suprida através da revisão desta norma (em andamento), a qual pretende abordar mais detalhadamente alguns critérios de projeto para garantia de durabilidade das estruturas, a exemplo do que faz o CEB-FIP Model Code 1990 (1993).

Este capítulo tem por finalidade apresentar as prescrições destes códigos e normas, discutindo os aspectos que devem ser considerados no projeto, de modo a garantir a durabilidade das estruturas. São abordados os princípios e a estratégia de projeto a serem adotados e introduzidos os conceitos de vida útil de projeto e classes de exposição. Os principais critérios de projeto são discutidos, dentre os quais, citam-se: escolha apropriada das formas estruturais, composição do concreto, 
qualidade e espessura do cobrimento, detalhamento adequado das armaduras e limitação da abertura das fissuras. Na seqüência, são apresentadas as medidas especiais de proteção contra deterioração em ambientes agressivos e salientadas a importância e a necessidade de elaborar planos de inspeção e de manutenção preventiva.

\subsection{PRINCÍPIOS E ESTRATÉGIA DO PROJETO}

Estruturas de concreto devem ser projetadas, construídas e utilizadas de modo que, sob as influências ambientais previstas, elas mantenham segurança, bom desempenho em serviço e aparência aceitável durante um determinado período de tempo, sem exigir altos custos imprevistos para manutenção e reparo.

É importante esclarecer que, para evitar que ocorram problemas relativos à durabilidade das estruturas, são necessários esforços coordenados de todos os envolvidos nas diversas fases do processo construtivo, desde o planejamento da construção até a sua utilização e manutenção. Assim, segundo a revisão da NB 1 (1994), deve haver uma cooperação entre as seguintes partes:

- O proprietário, definindo suas expectativas presentes e futuras de uso da estrutura;

- Os projetistas (engenheiros e arquitetos), preparando especificações de projeto e impondo condições de execução, uso e manutenção (incluindo propostas de esquemas de controle da qualidade);

- Os construtores, cumprindo as exigências e condições do projeto;

- Os usuários, obedecendo às condições de uso e efetuando a manutenção prevista.

Qualquer uma dessas quatro partes, através de suas ações ou na ausência delas, pode contribuir para um estado insatisfatório de durabilidade da estrutura e, portanto, pode causar uma redução da vida útil. 
Apesar de serem feitos comentários com relação a alguns aspectos referentes à execução, o enfoque principal concentra-se na fase de projeto, abordando as providências que devem ser tomadas neste estágio inicial.

O projeto deve adotar uma estratégia que iniba os processos de deterioração, através da adoção de medidas apropriadas de proteção, principalmente contra a corrosão das armaduras, que representa o mais freqüente, o mais importante e o mais conhecido mecanismo de deterioração. Esta estratégia deve considerar possíveis medidas para proteger a estrutura contra deterioração prematura, as quais vão depender da vida útil especificada para a estrutura e das condições ambientais.

\subsection{VIDA ÚTIL}

A vida útil é definida como o período de tempo durante o qual as estruturas de concreto mantêm condições satisfatórias de uso, preenchendo as finalidades para as quais foi projetada, sem a necessidade de manutenção dispendiosa.

A vida útil da construção como um todo depende igualmente do comportamento dos elementos estruturais de concreto armado e dos demais componentes incorporados à estrutura, porém, sem função estrutural, tais como drenos, juntas, apoios, instalações etc. Há que se considerar que estes elementos nãoestruturais, em geral, possuem vida útil mais curta do que a estrutura propriamente dita e, portanto, providências adequadas para sua manutenção, substituição e reparo devem ser previstas no projeto.

A extensão da vida útil varia com o tipo e a importância da estrutura. Assim, estruturas de caráter permanente devem ter, em geral, vida útil mais longa do que as de caráter provisório. O CEB-FIP Model Code 1990 (1993), por exemplo, afirma que as estruturas projetadas conforme suas recomendações têm grande probabilidade de apresentar vida útil de, pelo menos, 50 anos. Já a revisão da NB 1 (1994) recomenda vida útil de projeto de, pelo menos, 1 ano para estruturas de caráter provisório e, para pontes e obras de caráter permanente, 50, 75 ou até mais de 100 anos. 
Definida a extensão da vida útil desejada, cabe aos projetistas a função de especificar as medidas necessárias para assegurar que ela seja atingida, para isso levando em conta as condições ambientais e de exposição da estrutura.

\subsection{CONDIÇÕES AMBIENTAIS}

As condições ambientais correspondem às ações químicas e físicas às quais a estrutura de concreto é exposta e que resultam em efeitos não incluídos entre os efeitos de cargas ou ações previstas no projeto estrutural. Condições ambientais muito severas podem deteriorar as estruturas expostas, conduzindo ao colapso total ou parcial.

Para que os processos de deterioração se desenvolvam, é necessário que haja interações entre os materiais (concreto e aço) e o ambiente onde se encontram as estruturas. Tais interações dependem das propriedades dos materiais, da forma estrutural, da posição das armaduras e do grau de agressividade do ambiente.

As propriedades do ambiente devem ser claramente identificadas para fins de fixação de medidas mínimas de proteção das estruturas. O macroclima, de determinação relativamente fácil, através de métodos tradicionais, pouco influi na durabilidade das estruturas. O clima local ou o microclima, por outro lado, exercem influência decisiva neste aspecto. Entretanto, infelizmente, ainda não estão disponíveis métodos para uma determinação rigorosa de tais condições.

Existem, atualmente, muitas classificações das condições ambientais em uso. O CEB-FIP Model Code (1978) apud CEB Bulletin d'Information n.182 (1989) classificou as condições ambientais em suaves, moderadas e severas, correspondendo, respectivamente, a ambientes leve, moderada e altamente agressivos. Esta classificação serviu de orientação para a estimativa dos riscos de durabilidade associados a uma dada estrutura em um determinado ambiente.

Posteriormente, o Comité Européen de Normalisation (CEN, 1984) apud CEB Bulletin d'Information n.182 (1989) propôs uma classificação mais abrangente 
e mais detalhada, agrupando as condições ambientais em cinco classes de exposição, a saber: (1) ambiente seco; (2) ambiente úmido; (3) ambiente úmido sujeito a congelamento e sais de degelo; (4) ambiente marinho; e (5) ambiente quimicamente agressivo. As classes de exposição (2) e (4) ainda apresentavam subdivisões, conforme existência ou não de riscos de congelamento.

Adicionalmente, o CEN (1984) apud CEB Bulletin d'Information n.182 (1989) proporcionou meios para avaliação do grau de agressividade química da classe de exposição (5), fornecendo valores limites para os teores de agentes agressivos em água ou solo (valor de $\mathrm{pH}, \mathrm{CO}_{2}$ agressivo, amônia, sulfato etc.), classificando, assim, o nível de agressividade química em fraco, moderado, forte e muito forte.

Para o projeto de edificações usuais, na ausência de um estudo mais específico, as condições ambientais podem ser simplificadamente relacionadas nas classes de exposição dadas na Tabela 4.1. Esta classificação é proposta pelo CEB-FIP Model Code 1990 (1993) e pelo Eurocode 2 (1992), os quais se baseiam no esquema proposto pelo CEN (1984). A revisão da NB 1 (1994) segue a mesma linha.

A classificação das condições ambientais, conforme apresentada na Tabela 4.1, refere-se ao microambiente e não ao macroambiente. Em outras palavras, essas condições são referidas ao ambiente nas proximidades do ponto considerado na superfície externa da estrutura ou do elemento estrutural. Assim, por exemplo, o conteúdo de água nas camadas superficiais do concreto (microambiente), em geral, é maior do que a correspondente umidade relativa do ar (macroambiente), visto que a absorção de água pelo concreto é mais rápida do que a secagem.

Os diferentes níveis de agressividade do microambiente de uma estrutura podem ser considerados através de uma estratégia de zoneamento. Assim, os elementos da estrutura, ou as partes mais desfavoravelmente afetadas desses elementos, podem ser considerados como pertencentes a diferentes zonas, dependendo da agressividade do microambiente previsto. 
Tabela 4.1 - Classes de exposição referidas às condições ambientais.

(CEB-FIP Model Code 1990, 1993)

\begin{tabular}{|c|c|c|}
\hline \multirow{2}{*}{\multicolumn{2}{|c|}{$\frac{\text { Classes de exposição }}{\text { 1. Ambiente seco }}$}} & \multirow{2}{*}{$\begin{array}{l}\text { Condições ambientais } \\
\text { - interior de edifícios para habitação ou } \\
\text { escritórios (1) }\end{array}$} \\
\hline & & \\
\hline \multirow[t]{2}{*}{$\begin{array}{l}\text { 2. Ambiente } \\
\text { úmido }\end{array}$} & $\begin{array}{l}\text { a. } \\
\text { sem } \\
\text { congelamento }\end{array}$ & $\begin{array}{l}\text { - interior de edifícios onde a umidade é } \\
\text { alta (2) } \\
\text { - elementos externos } \\
\text { - elementos em solo ou água não-agressivos }\end{array}$ \\
\hline & $\begin{array}{l}\text { b. } \\
\text { com } \\
\text { congelamento }\end{array}$ & $\begin{array}{l}\text { - elementos internos onde a umidade é alta, } \\
\text { expostos a congelamento } \\
\text { - elementos externos expostos a congelamento } \\
\text { - elementos em solo ou água não-agressivos, } \\
\text { expostos a congelamento }\end{array}$ \\
\hline \multicolumn{2}{|c|}{$\begin{array}{l}\text { 3. Ambiente úmido com congela- } \\
\text { mento e agentes para degelo. }\end{array}$} & $\begin{array}{l}\text { - elementos internos e externos expostos a } \\
\text { congelamento e agentes para degelo }\end{array}$ \\
\hline \multirow[t]{2}{*}{$\begin{array}{l}\text { 4. Ambiente } \\
\text { marinho }\end{array}$} & $\begin{array}{l}\text { a. } \\
\text { sem } \\
\text { congelamento }\end{array}$ & $\begin{array}{l}\text { - elementos parcialmente imersos em água do mar } \\
\text { ou na zona de arrebentação } \\
\text { - elementos em ar saturado de sal, como na zona } \\
\text { costeira }\end{array}$ \\
\hline & $\begin{array}{l}\text { b. } \\
\text { com } \\
\text { congelamento }\end{array}$ & $\begin{array}{l}\text { - elementos parcialmente imersos em água do mar } \\
\text { ou na zona de arrebentação e expostos a } \\
\text { congelamento } \\
\text { - elementos em ar saturado de sal e expostos a } \\
\text { congelamento }\end{array}$ \\
\hline \multicolumn{3}{|c|}{ As classes seguintes podem ocorrer isoladas ou em combinação com as anteriores: } \\
\hline \multirow[t]{3}{*}{$\begin{array}{l}\text { 5. Ambiente } \\
\text { quimicamente } \\
\text { agressivo }\end{array}$} & a. & $\begin{array}{l}\text { - elementos em contato com solo, líquido ou gás, } \\
\text { com baixa agressividade química } \\
\text { - atmosfera industrial agressiva }\end{array}$ \\
\hline & b. & $\begin{array}{l}\text { - elementos em contato com solo, líquido ou gás, } \\
\text { com moderada agressividade química }\end{array}$ \\
\hline & c. & $\begin{array}{l}\text { - elementos em contato com solo, líquido ou gás, } \\
\text { com alta agressividade química }\end{array}$ \\
\hline
\end{tabular}

(1) Esta classe é válida desde que durante a construção a estrutura ou seus componentes não sejam expostos a condições mais severas, durante um período de muitos meses.

(2) Por exemplo, em lavanderias comerciais. 


\subsection{CRITÉRIOS DE PROJETO}

A estratégia de projeto deve considerar as medidas que preservem e protejam a estrutura contra sua deterioração prematura. Usualmente, são empregadas várias medidas de proteção, convenientemente escolhidas com a devida consideração das condições ambientais, visando assegurar que a vida útil especificada seja atingida. Tais medidas podem ser estabelecidas, por exemplo, através de:

- escolha apropriada da forma estrutural dos elementos;

- determinação da composição do concreto;

- definição da qualidade do concreto e da espessura do cobrimento;

- detalhamento adequado das armaduras;

- limitação da abertura nominal das fissuras;

- medidas especiais de proteção para ambientes especialmente agressivos;

- procedimentos especificados de inspeção e manutenção durante o uso da estrutura;

- consideração de aspectos relativos à qualidade da execução.

Portanto, o projeto para durabilidade deve definir formas estruturais, dimensões e arranjos de armadura apropriados, apresentar especificações adequadas para os materiais, propor recomendações para a execução, com vistas à garantia da qualidade do concreto produzido e, finalmente, fornecer aos usuários planos de inspeção e de manutenção preventiva.

\subsubsection{Forma Estrutural}

A forma das estruturas expostas de concreto tem influência decisiva na interação dos materiais com o meio ambiente. A consideração da vida útil requerida quando da elaboração do projeto arquitetônico pode resultar em melhorias consideráveis na durabilidade da estrutura.

Deve ser selecionada, na fase inicial do projeto, uma forma estrutural adequada, de modo a evitar arranjos estruturais muito sensíveis. A complexidade da 
forma estrutural, em geral, aumenta a sensibilidade da estrutura com relação à deterioração e pode, conseqüentemente, provocar uma redução da sua vida útil. Além disso, formas complexas, em geral, requerem maiores esforços para execução e manutenção do que as formas simples. Portanto, maior atenção na concepção e na execução desse tipo de estrutura é sempre recomendável.

Devem-se tomar os devidos cuidados para que a forma estrutural proporcione resistência suficiente contra penetração de substâncias prejudiciais líquidas ou gasosas. Esta resistência está parcialmente associada à relação entre a área da superfície exposta e o respectivo volume de concreto. Quanto maior for esta relação, maior será o risco de uma substância nociva penetrar no concreto em quantidade suficiente para desencadear algum mecanismo de deterioração do próprio concreto ou da armadura.

O projeto deve, sempre que possível, assegurar acesso adequado a todas as partes da estrutura, para permitir inspeção e possível manutenção a ser realizada durante toda a vida útil prevista.

A água se acumula, principalmente, nas interseções das superfícies horizontais com as verticais expostas, onde o pó e a sujeira se concentram, mantendo, assim, o concreto úmido no local por um período prolongado de tempo. A geometria dos elementos deve minimizar os riscos de concentrações locais de substâncias nocivas. Nesses casos, recomenda-se a seleção de cantos e arestas arredondados e a utilização de chanfros, que reduzem os efeitos nocivos dessa concentração, aumentando, assim, a durabilidade da estrutura.

A aparência da estrutura é bastante afetada pela descoloração causada por pó, sujeira e fuligem depositados nas superfícies de concreto, principalmente nas verticais. No projeto, devem ser feitas tentativas para minimizar a possibilidade de ocorrência de tais depósitos e para tirar proveito da lavagem natural que pode ser proporcionada pela água da chuva. Para isto, deve ser previamente planejada a canalização da água nas superfícies das estruturas, atentando para o detalhamento das fachadas das construções. 
Assim, todas as superfícies de concreto expostas devem ser adequadamente drenadas, protegendo-se, tanto quanto possível, as regiões das juntas e vedações e evitando as situações em que a própria drenagem lança água sobre o concreto da estrutura ou sobre as juntas. Se possível, buracos e vazios internos na estrutura devem ser drenados e ventilados, de modo a prevenir a corrosão das armaduras causada pela água eventualmente acumulada nesses locais.

\subsubsection{Composição do Concreto}

Segundo a revisão da NB 1 (1994), uma diretriz geral, encontrada na literatura técnica, diz que a durabilidade da estrutura de concreto é determinada por quatro fatores relacionados com as características deste material, e identificados conjuntamente como os 4C: Composição, Compactação, Cura e Cobrimento.

Os requisitos para a composição do concreto dependem das condições ambientais às quais a estrutura é exposta. Na Tabela 4.2, são fornecidas algumas indicações referentes à máxima relação água/cimento e às classes de concreto a serem adotadas, em função das classes de exposição, conforme definidas na Tabela 4.1 .

Tabela 4.2 - Composição do concreto em função das classes de exposição.

\begin{tabular}{|c|c|c|c|c|c|}
\hline Classes de exposição & 1 & 2 & 3 & $4 *$ & $5 *$ \\
\hline $\begin{array}{l}\text { Máxima relação água/cimento (em } \\
\text { massa) }\end{array}$ & 0,60 & 0,55 & 0,50 & 0,50 & 0,45 \\
\hline Classe mais baixa (para concreto armado) & C20 & $\mathrm{C} 25$ & C30 & C35 & C35 \\
\hline
\end{tabular}

* a) Alguns autores recomendam limitar a relação água-cimento em 0,40, em casos de exposição severa, tendo em vista a proteção das armaduras contra a corrosão.

b) Recomenda-se proteger o concreto do contato direto com o meio agressivo, através de pinturas ou revestimentos adequados, associados a condições rigorosas de cura. 
Embora um concreto de resistência mais alta seja, em certas circunstâncias, mais durável do que um concreto de resistência mais baixa, a resistência à compressão não é, por si só, uma medida completa da durabilidade do concreto, pois esta depende, primariamente, das propriedades das camadas superficiais da peça, as quais têm efeito limitado em sua resistência à compressão. A moldagem e a cura, ao contrário, têm influência decisiva sobre a permeabilidade dessas camadas. Apesar disso, decidiu-se fazer referência, na Tabela 4.2, às classes de resistência do concreto, por ser esta a especificação consagrada nos projetos.

Cuidados especiais devem ser tomados para assegurar um concreto de alta qualidade e impermeabilidade nas camadas superficiais das peças de concreto armado.

Os valores da Tabela 4.2 são válidos apenas para concretos feitos com cimentos que atendam às especificações para os cimentos Portland I, II, III, IV e V, respectivamente, NBR 5732, NBR 11578, NBR 5735 NBR 5736 e NBR 5733.

Os concretos que devam ter baixa permeabilidade, pela condição de estanqueidade (estruturas hidráulicas e sanitárias), devem ter relação água/cimento máxima (em peso) de 0,50 e, além disso, teor mínimo de cimento de $350 \mathrm{~kg} / \mathrm{m}^{3}$, referindo-se ao concreto de classe mínima C25. Em peças com espessura maior do que $50 \mathrm{~cm}$, este valor máximo pode ser elevado para 0,55.

Concretos em contato com água com teor de sulfatos $\left(\mathrm{SO}_{4}\right)$ superior a $600 \mathrm{mg} / \mathrm{dm}^{3}$, ou em contato com solos com teor de sulfatos superior a $3.000 \mathrm{mg} / \mathrm{kg}$, devem utilizar cimentos resistentes a sulfatos, respeitar relação máxima água/cimento igual a 0,45 e classe mínima C30. Dispensa-se o uso de cimento resistente a sulfato, nas peças em presença da água do mar. Cimentos do tipo Portland, com teor de $\mathrm{C}_{3} \mathrm{~A}$ (aluminato tricálcico) inferior a 8\%, em massa, são considerados cimentos resistentes a sulfatos. Para uma especificação mais detalhada, em função da concentração de sulfatos, recomenda-se consultar a Tabela 7.7 de NEVILLE (1982).

Os concretos sujeitos a intensa deterioração mecânica, como mencionado no item 3.5.1, devem ter resistência característica à compressão, pelo menos, igual a 
$40 \mathrm{MPa}$, slump máximo de $9 \mathrm{~cm}$ e apresentar textura de superfície bem compacta, sem presença de nata excedente de cimento, além de exigirem cura mais prolongada do que a usual em outros tipos de concreto.

Aditivos com proporções prejudiciais de cloretos não devem ser aplicados em estruturas de concreto armado, tendo em vista a proteção das armaduras contra a corrosão.

\subsubsection{Qualidade e Espessura do Cobrimento}

O cobrimento, definido como a menor distância entre qualquer superfície de concreto e a superfície da barra da armadura mais próxima, é uma das principais medidas de proteção das estruturas de concreto armado, principalmente com relação à prevenção da corrosão das armaduras. Dois aspectos precisam ser considerados: a qualidade do concreto e a espessura do cobrimento.

Deve-se garantir uma qualidade adequada do concreto nas camadas superficiais dos elementos estruturais. É necessário que este concreto seja denso, bem compactado e bem curado, resistente e de baixa permeabilidade e que não apresente fissuras com aberturas excessivas. Conforme dito anteriormente, as condições de moldagem e de cura exercem influência decisiva na permeabilidade desse concreto superficial.

A espessura do cobrimento depende das condições de exposição dos elementos estruturais, sendo fornecidos, na Tabela 4.3, os valores mínimos. Os valores nominais que devem ser especificados no projeto são obtidos somando-se aos valores da Tabela 4.3 as tolerâncias de montagem. Estas devem ser tomadas iguais a $10 \mathrm{~mm}$, a menos que seja demonstrada a possibilidade de utilizar um valor menor. Em nenhum caso será permitido adotar tolerância menor do que $5 \mathrm{~mm}$. 
Tabela 4.3 - Cobrimentos mínimos, em mm.

(CEB-FIP Model Code 1990, 1993)

\begin{tabular}{c|c|c|c|c|c}
\hline Classe de exposição & 1 & 2 & 3 & 4 & 5 \\
$\mathrm{c}_{\min }$ & 10 & 25 & 40 & 40 & $*$ \\
\hline
\end{tabular}

* Depende do tipo de ambiente encontrado.

Os valores nominais de cobrimento correspondem a valores característicos inferiores, ou seja, devem ser efetivamente ultrapassados em pelo menos $95 \%$ das vezes durante a montagem e a concretagem.

No caso de concretos de classe acima de C30, exceto em ambientes especialmente agressivos, os cobrimentos nominais obtidos a partir dos valores da Tabela 4.3 podem ser reduzidos de $5 \mathrm{~mm}$, respeitando-se, entretanto, o valor mínimo de $20 \mathrm{~mm}$.

Em tanques, caixas d'água, estações elevatórias, canais, condutos e canalizações, independentemente dos valores obtidos através da Tabela 4.3, deve ser adotado cobrimento nominal de, pelo menos, $40 \mathrm{~mm}$.

Para ambientes considerados moderada ou severamente agressivos com relação à corrosão de armaduras, o ACI 201.2R (1992) recomenda que o cobrimento seja de, no mínimo, $38 \mathrm{~mm}$ e, de preferência, $50 \mathrm{~mm}$. Ainda segundo o ACI 201.2R (1992), para concretos submetidos a condições severas de esposição em ambientes marinhos, deve-se utilizar cobrimento mínimo de $75 \mathrm{~mm}$.

Com vistas à garantia de resistência contra o fogo, convém adotar cobrimento, no mínimo, igual a $30 \mathrm{~mm}$.

\subsubsection{Detalhamento das Armaduras}

O projeto deve considerar o detalhamento das armaduras como forma de aumentar a autoproteção e a robustez da estrutura contra a agressividade ambiente.

As armaduras devem ser suficientemente distribuídas nas respectivas zonas de concreto, de modo a assegurar que a concretagem e o adensamento sejam 
executados de forma correta e confiável, principalmente nas camadas superficiais de concreto. Deve-se respeitar uma taxa máxima, a fim de evitar o congestionamento da armadura que possa resultar em condições precárias de concretagem, propiciando a segregação do concreto, impedindo um bom adensamento e dando lugar a defeitos de concretagem.

Um detalhamento adequado da armadura de componentes estruturais de concreto armado deve assegurar a integridade de superfícies, bem como de cantos e arestas críticos, de modo a evitar qualquer concentração imprevista de influências agressivas.

Deve-se dispor uma taxa mínima de armadura necessária para o controle de fissuração, conforme será discutido no item seguinte.

\subsubsection{Limitação da Abertura das Fissuras}

Juntamente com a qualidade do concreto e a espessura do cobrimento, o controle da abertura nominal das fissuras é extremamente importante para garantir a proteção das armaduras contra a corrosão.

Desvios abruptos de forças na estrutura e mudanças bruscas de seções causam concentrações de tensões capazes de provocar grandes fissuras localizadas. Forças de restrição, devidas a recalques diferenciais, retração e efeitos de temperatura, podem também ocasionar grandes fissuras. Tais condições estruturais devem, na medida do possível, ser evitadas. Os riscos de tais fissuras devem ser combatidos com um detalhamento apropriado da armadura, através da disposição de armadura mínima de pele.

O controle de fissuração tem por objetivo principal dificultar a penetração de substâncias nocivas no concreto, responsáveis pelo desencadeamento do processo de corrosão das armaduras.

Aberturas de fissuras até $0,4 \mathrm{~mm}$ em peças de concreto armado sob as condições de exposição 1 a 4, sob combinação quase-permanente de ações, são 
satisfatórias para as exigências de durabilidade. Aberturas menores do que $0,4 \mathrm{~mm}$ não influem na evolução da corrosão das armaduras. Entretanto, deve-se limitar a abertura das fissuras nos casos em que estas afetam a funcionalidade das peças (como é o caso da estanqueidade exigida para reservatórios), causam insegurança ou desconforto aos usuários e, também, em ambientes agressivos (classe de exposição $5)$.

Nas peças em ambientes muito agressivos, ao contrário, a limitação da abertura das fissuras em valores abaixo de $0,4 \mathrm{~mm}$ não é suficiente para prevenir a corrosão das armaduras, visto que a penetração das substâncias nocivas ocorre através de fissuras com aberturas bem menores. Nestes casos, recomenda-se a adoção de medidas especiais de proteção.

\subsubsection{Medidas Especiais de Proteção}

Nos casos de ambientes especificamente agressivos, em que as providências normais para assegurar a vida útil requerida não são suficientes, medidas especiais de proteção devem ser aplicadas. Identificam-se as seguintes medidas especiais de proteção, que podem ser empregadas isolada ou associadamente:

- aumento do cobrimento (deve-se dispor uma armadura de pele nos casos em que o cobrimento for maior ou igual a $70 \mathrm{~mm}$ );

- proteção direta da superfície da peça pela aplicação de camadas protetoras:

* pinturas ou membranas impermeabilizantes (à base de acrílico, de epóxi, de asfalto, de silicone, de poliuretano ou com combinação de produtos, formando sistemas duplos);

* camadas espessas, utilizando combinações de pinturas com mantas de náilon, de fibras de vidro ou de poliéster;

- proteção direta da armadura pela aplicação de pinturas apropriadas;

- proteção direta da armadura pela utilização de proteção catódica;

- intensas rotinas de inspeção e de manutenção para acompanhar o desempenho da estrutura. 


\subsubsection{Planos de Inspeção e de Manutenção}

O projeto deve levar em consideração os planos de inspeção e de manutenção previstos para a estrutura. Os elementos mais vulneráveis, que exigem inspeção e manutenção mais intensas, devem ser claramente identificados na fase de projeto.

Inspeções regulares e sistemáticas da estrutura e de todos os acessórios (drenos, juntas, instalações etc.) devem, sempre que possível e apropriado, ser exercidas ao longo de toda a vida útil prevista para a estrutura. Para minimizar custos futuros com manutenção e reparo, as rotinas de inspeção devem, tanto quanto possível, revelar deterioração iminente e desempenho inadequado, em tempo hábil para que possa ser aplicada manutenção preventiva, ou seja, deve-se identificar o ponto de transição entre a Fase de Iniciação e a Fase de Propagação, conforme apresentado no item 3.2, Figura 3.1.

Os acessórios, geralmente, possuem vida útil mais curta do que a estrutura propriamente dita e, portanto, atividades de manutenção, reparo e substituição desses elementos devem ser previstos no projeto e durante o uso.

\subsection{ASPECTOS RELATIVOS À EXECUÇÃO}

No projeto devem ser considerados os aspectos referentes aos processos construtivos previstos para a estrutura, de modo a viabilizar e otimizar a execução.

A qualidade da execução deve ser minuciosamente especificada e posteriormente controlada e documentada durante a fase de construção, visto que exerce influência significativa na qualidade do concreto e nas dimensões obtidas na estrutura (cobrimento, por exemplo). Tendo em vista a durabilidade, é essencial que os devidos cuidados sejam tomados na fase de execução, de modo a obter níveis satisfatórios de qualidade, principalmente no que se refere ao lançamento, ao adensamento e à cura do concreto. Os procedimentos de controle devem considerar tipo, forma, complexidade e sensibilidade da estrutura, tipo e grau de agressividade do ambiente e, também, experiência e competência do construtor. 
Um adensamento mal executado pode resultar em alto índice de vazios, produzindo, assim, um concreto altamente poroso. Uma cura insuficiente, por sua vez, produz baixo grau de hidratação do cimento, especialmente nas regiões superficiais, resultando em alta permeabilidade do concreto de superfície e, conseqüentemente, baixa durabilidade das peças. Realmente, isto se explica pelo fato de que a permeabilidade depende da interligação dos poros, e esta ligação será tanto maior quanto menor for o grau de hidratação do cimento.

O aumento da porosidade e, por conseqüência, da permeabilidade do concreto facilitam a penetração de substâncias nocivas, tornando-o mais suscetível aos ataques por agentes agressivos que podem conduzir à deterioração tanto do próprio concreto como do aço. 


\section{APLICAÇÕES}

Neste capítulo, pretende-se apresentar alguns exemplos de aplicação prática dos conceitos e procedimentos expostos ao longo do trabalho. O objetivo primordial é demonstrar a aplicação da metodologia proposta no Capítulo 2 para o controle da qualidade de projetos. Esta atividade, conforme esclarecido anteriormente, inclui a verificação da segurança com relação aos estados limites últimos e de utilização e, também, a observância dos critérios de projeto para durabilidade, alguns dos quais foram apresentados e discutidos no Capítulo 4.

Os exemplos a seguir apresentados consistem, basicamente, em descrições de atividades relativas ao controle da qualidade de projetos reais, desenvolvidas num escritório de cálculo de estruturas. Por se tratar de atividade relativamente recente e pouco difundida, dispunham-se de muito poucas referências na literatura técnica e, uma certa dificuldade inicial do meio técnico na implementação do controle foi inevitável.

Assim, o primeiro passo consistiu na elaboração de diretrizes para planejar, ordenar e disciplinar as ações do controle da qualidade de projetos. À medida que as diretrizes foram sendo postas em prática, perceberam-se seus acertos e desacertos, os quais motivaram a introdução de modificações no texto original, de modo a compatibilizar a teoria e a prática. Estas diretrizes, propostas por LARANJEIRAS (1993), serviram de base para a elaboração do Capítulo 2 deste trabalho.

Os exemplos revelam os resultados efetivos do controle da qualidade, evidenciando sua importância no aperfeiçoamento do projeto e, conseqüentemente, sua contribuição para a melhoria da qualidade das estruturas. 
Vale ressaltar que, nestes exemplos, pode-se dizer que os resultados positivos alcançados deveram-se ao bom relacionamento e nível de comunicação entre os responsáveis pelo projeto e os responsáveis pelo controle da qualidade. De fato, havia uma cooperação entre as duas partes mencionadas, de modo que as críticas e sugestões apontadas pelo controle da qualidade foram discutidas e algumas, posteriormente, aceitas pelos projetistas, os quais providenciaram as respectivas alterações no projeto original.

Esta situação, entretanto, nem sempre é a que prevalece. Às vezes, os projetistas não aceitam as sugestões propostas pelo controle da qualidade, por interpretarem esta intervenção como um insulto à sua competência e capacidade técnica. Como consequiência, tem-se a ineficiência do controle da qualidade, cujos resultados são simplesmente ignorados e arquivados, sem que nenhuma providência seja tomada com relação ao aprimoramento do projeto. Além disso, cria-se uma situação permanente de desconforto e inimizade entre as partes envolvidas.

\subsection{EDIFÍCIO RESIDENCIAL}

O primeiro exemplo a ser apresentado consiste no controle da qualidade do projeto estrutural de um edifício residencial, situado num bairro nobre de Salvador. O prédio era constituído por 20 pavimentos, sendo 4 níveis de garagem (pav. 1 a 4), um piso destinado a áreas sociais ou play-ground (pav. 5), 14 pisos de apartamentos tipo duplex (pav. 6 a 19) e um nível de cobertura (pav. 20). O prédio contava, ainda, com reservatório inferior e, acima do nível da cobertura, casa de máquinas e reservatório superior.

O nível do play-ground coincidia com o nível do passeio, de modo que as garagens ficavam todas abaixo do nível da rua, sem entretanto serem completamente enterradas, dada a declividade do terreno natural. Do play-ground à cobertura contavam-se, aproximadamente, $42 \mathrm{~m}$. As figuras 5.1 e 5.2 ilustram o edifício ora descrito, de forma esquemática, através de uma vista superior, indicando suas dimensões em planta, e um corte longitudinal. 


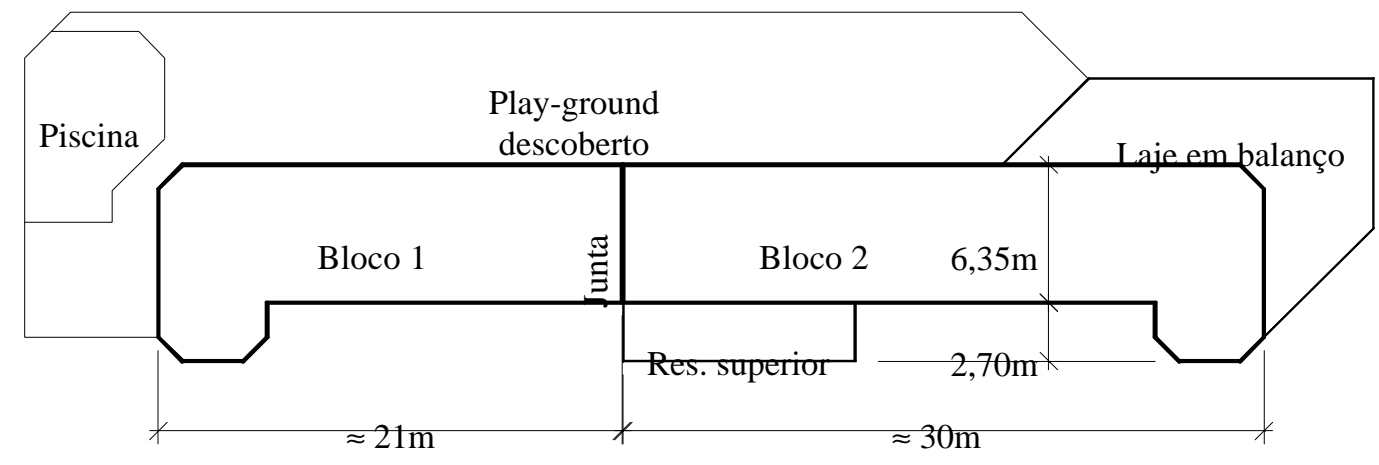

Figura 5.1 - Vista superior do edifício (desenho esquemático).

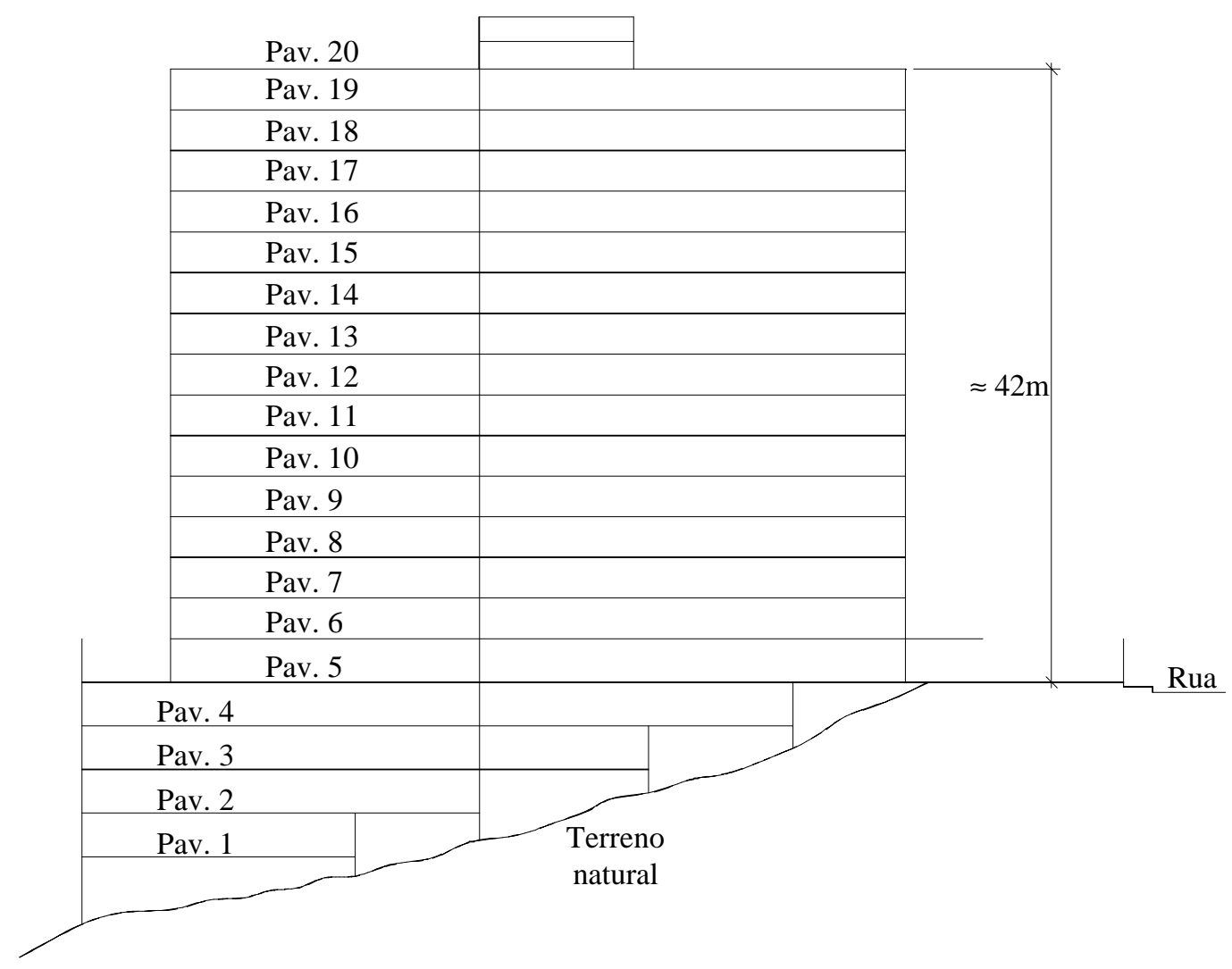

Figura 5.2 - Corte longitudinal do edifício (desenho esquemático). 
Na Figura 5.3 está indicada a disposição dos pilares nos dois blocos que compõem o edifício. Na Figura 5.4, representa-se, simplificadamente, um trecho da planta de forma dos níveis de apartamentos. Os apartamentos tipo duplex compunham-se de dois pisos. Em ambos os pisos, pode-se perceber a ausência de vigas rígidas interligando os pilares no plano longitudinal, sendo que, nos pisos superiores (pavimentos 7, 9, 11, 13, 15, 17 e 19), esta situação se torna ainda mais crítica, devido aos espaços vazios entre os pilares. A Figura 5.4 representa um detalhe típico da estrutura dos pisos de apartamentos, repetindo-se de forma similar entre os pilares P1-P2-P3-P4A, P4B-P5-P6-P7-P8, P9-P10 e P16-P17.

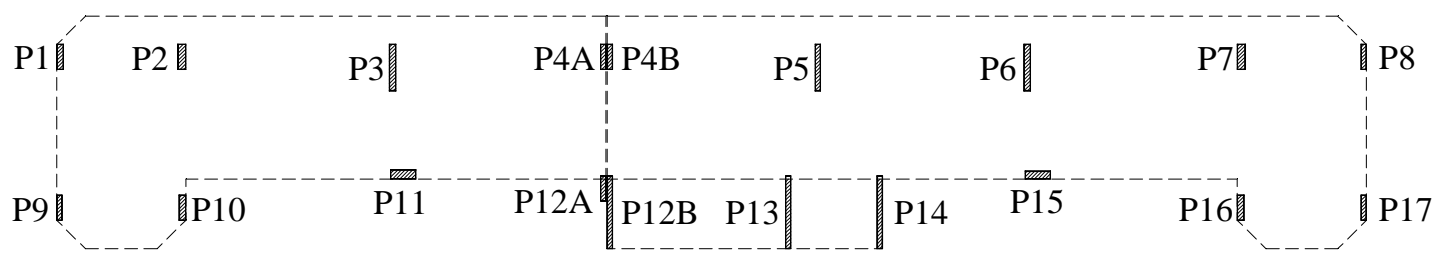

Figura 5.3 - Locação dos pilares (desenho esquemático).

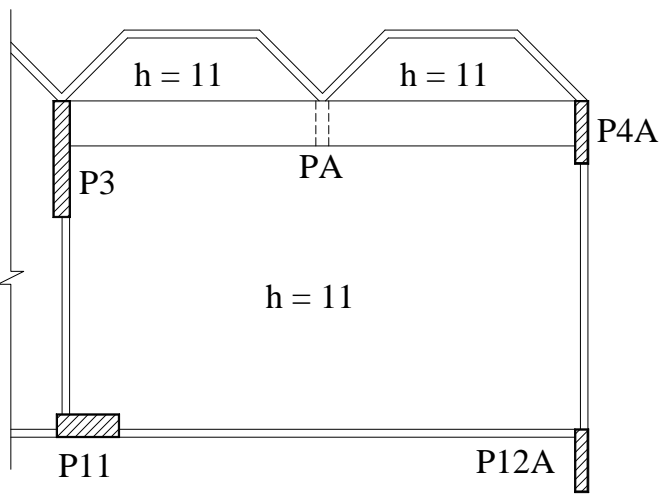

a) Pavimentos 6, 8, 10, 12, 14, 16 e 18

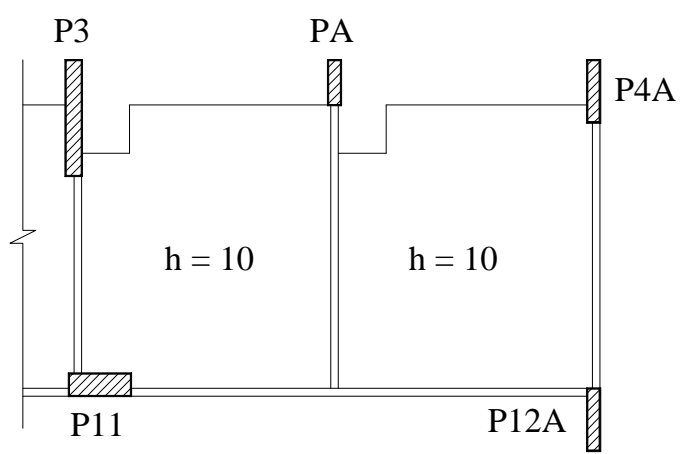

b) Pavimentos 7, 9, 11, 13, 15, 17 e 19

Figura 5.4 - Detalhe da planta de formas dos pisos de apartamentos (desenho esquemático).

Os serviços de controle da qualidade do projeto estrutural do edifício mencionado foram executados por um escritório de cálculo independente daquele que elaborou o projeto, sob encomenda da empresa responsável pela construção. 
Nesta empresa, havia sido introduzida uma filosofia, considerada pioneira em Salvador, de submeter todo projeto a uma verificação preliminar, antes de sua liberação para execução propriamente dita.

Tendo sido este um dos primeiros serviços relativos a controle da qualidade de projetos, realizados por aquele escritório de cálculo, procurou-se seguir, na medida do possível, a metodologia proposta no item 2.3. Assim, o primeiro passo consistiu na identificação de todos os documentos de referência disponíveis (ver item 2.3.1).

Em seguida, procederam-se as verificações necessárias para avaliar a qualidade do projeto com relação à sua capacidade de conferir à estrutura: segurança, bom desempenho em serviço e durabilidade. Como não se dispunha da memória de cálculo, utilizou-se a técnica da verificação parcial (ver item 2.3.2.A), realizando-se os cálculos apenas para pontos críticos e elementos representativos da estrutura, convenientemente escolhidos.

Por se tratar de um edifício alto e esbelto, a preocupação inicial do controle da qualidade consistiu em verificar a sua estabilidade global, ou seja, sua capacidade de resistir às ações horizontais. De fato, este foi um dos principais aspectos analisados, tendo inclusive o controle da qualidade explorado bastante este assunto no relatório conclusivo elaborado no final das atividades, procurando alertar os projetistas, e também a construtora, da necessidade de aumentar a rigidez do edifício à ação do vento.

Um outro aspecto do projeto bastante observado pelo controle da qualidade refere-se à pequena rigidez das lajes à flexão, o que poderia conduzir a deformações exageradas em serviço, trazendo prejuízos não só para a estrutura em si, mas também para elementos não-estruturais, como as alvenarias, por exemplo.

Com base nos resultados dos cálculos efetuados pelo pessoal do controle da qualidade, as informações contidas nos desenhos foram, então, classificadas em nãoconformidades ou divergências, como indicado no item 2.3.3. 
Comunicados sobre a detecção de deficiências no projeto original, os projetistas realizaram algumas poucas modificações e o projeto passou por novas verificações. Terminada esta fase de realimentação do projeto (ver item 2.3.4), foi elaborado, finalmente, um relatório conclusivo, sintetizando os resultados das verificações efetuadas e propondo sugestões para eliminar as falhas encontradas.

O relatório conclusivo é a seguir apresentado. Vale, neste momento, tecer alguns comentários a respeito do modelo utilizado para a apresentação deste relatório. O modelo é composto por vários quadros, onde se identificam o projeto analisado (Quadro 1), os documentos fornecidos ao pessoal do controle da qualidade para análise (Quadro 2), os documentos de referência disponíveis (Quadro 3), as nãoconformidades anotadas (Quadro 4), as divergências relevantes (Quadro 5) e as conclusões com relação à qualidade do projeto (Quadros 6 e 7).

Percebe-se que este modelo tem um formato que favorece a ordenação das atividades do controle da qualidade. Entretanto, apresenta um inconveniente grave. Os quadros 6 e 7, relativos às conclusões do relatório, podem, em certos casos, conduzir a uma interpretação errada sobre a qualidade do projeto.

Imagine, por exemplo, que após analisar todo um projeto, apenas uma laje de pouca representatividade na estrutura tenha apresentado problemas de deformações exageradas. Neste caso, no item 2 do Quadro 7, deveria ser assinalada a coluna correspondente à resposta NÃO. Uma resposta negativa, tanto no Quadro 6 como no 7, pode ser entendida como se estivesse referida ao projeto como um todo.

No caso do exemplo citado no parágrafo anterior, esta seria uma interpretação errada, pois a exigência da qualidade com relação ao estado limite de deformações excessivas só não foi cumprida para uma única laje, o que, dada a pequena importância deste elemento na estrutura, praticamente não afeta a qualidade do projeto. Este, no entanto, não é o caso do projeto analisado, que, de fato, apresentou uma série de deficiências graves, que precisaram ser corrigidas. 
A memória de cálculo das verificações efetuadas pelo controle da qualidade foi omitida, por conveniência, constando do relatório que segue, apenas os resultados obtidos nestas verificações.

CONTROLE DA QUALIDADE DO PROJETO ESTRUTURAL DO EDIFÍCIO RESIDENCIAL .....

Data:

Quadro 1: IDENTIFICAÇÃO

Obra:

Contratante do C.Q.:

Contato:

Responsável pelo projeto:

Responsável pelo C.Q.:

Quadro 2: DOCUMENTOS DO PROJETO SOB CONTROLE DA QUALIDADE

\begin{tabular}{|c|c|}
\hline Desenho $n^{\circ}$ & Título \\
\hline 01 & Locação e cargas \\
\hline 02 & Corte esquemático e escada \\
\hline 03 a 12 & Pilares \\
\hline 13 & Detalhe da rampa \\
\hline 14 & Forma e ferragem do $1^{\circ}$ teto \\
\hline 15 a 18 & Vigas do $1^{\circ}$ teto \\
\hline 19 & Forma e ferragem do $2^{\circ}$ teto \\
\hline 20 a 23 & Vigas do $2^{\circ}$ teto \\
\hline 24 & Forma e ferragem do $3^{\circ}$ teto \\
\hline 25 a 29 & Vigas do $3^{\circ}$ teto \\
\hline 30 & Forma e ferragem do $4^{\circ}$ teto \\
\hline 31 a 35 & Vigas do $4^{\circ}$ teto \\
\hline 36 & Forma do $5^{\circ}$ teto \\
\hline
\end{tabular}




\begin{tabular}{|cl|}
\hline 37 & Ferragem do $5^{\circ}$ teto \\
38 a 44 & Vigas do $5^{\circ}$ teto \\
45 & Forma do $6^{\circ}$ teto \\
46 & Ferragem do $6^{\circ}$ teto \\
47 a 50 & Vigas do $6^{\circ}$ teto \\
51 & Forma do $7^{\circ}$ ao $19^{\circ}$ tetos \\
52 & Ferragem do $7^{\circ}, 9^{\circ}, 11^{\circ}, 13^{\circ}, 15^{\circ}, 17^{\circ}$ e $19^{\circ}$ tetos \\
53 e 54 & Vigas do $7^{\circ}, 9^{\circ}, 11^{\circ}, 13^{\circ}, 15^{\circ}, 17^{\circ}$ e $19^{\circ}$ tetos \\
55 & Ferragem do $8^{\circ}, 10^{\circ}, 12^{\circ}, 14^{\circ}, 16^{\circ}$ e $18^{\circ}$ tetos \\
56 e 57 & Vigas do $8^{\circ}, 10^{\circ}, 12^{\circ}, 14^{\circ}, 16^{\circ}$ e $18^{\circ}$ tetos \\
58 & Forma do $20^{\circ}$ teto \\
59 & Ferragem do $20^{\circ}$ teto \\
60 e 61 & Vigas do $20^{\circ}$ teto \\
62 & Forma e ferragem do $21^{\circ}$ e $22^{\circ}$ tetos e do reservatório superior \\
63 & Vigas do $21^{\circ}$ e $22^{\circ}$ tetos e dos muros do reservatório superior \\
64 & Detalhes das cortinas \\
\hline
\end{tabular}

\section{Quadro 3: DOCUMENTOS DE REFERÊNCIA OFICIAIS ADOTADOS}
$N^{\circ}$ Descrição
1 Projeto arquitetônico (desenhos 01 a 04)
2 Projeto de fundações (desenho 01)
3 Norma Brasileira NBR 6118 (1978)
4 Código Modelo CEB-FIP Model Code 1990 (1991): Design Code
5 N orma ACI 350R (1983): Concrete Sanitary Engineering Structures

\section{Quadro 4: LISTAG ENS DAS NÃ O-CONFORMIDADES (N-C) ANOTADAS}

Critério de avaliação:

O - a manutenção desta N-C NÃO compromete significativamente a qualidade do projeto (e da estrutura)

1 - a manutenção desta N-C compromete significativamente a qualidade do projeto (e da estrutura)

\begin{tabular}{|c|l|c|c|c|}
\hline $\mathrm{N} \circ$ & Descrição da N-C & $\begin{array}{c}\text { Doc. } \\
\text { Ref. } \\
\text { Oficial }\end{array}$ & $\begin{array}{c}\text { Des. } \\
\mathrm{n}^{\circ}\end{array}$ & $\begin{array}{c}\text { Aval. } \\
(0 / 1)\end{array}$ \\
\hline 01 & $\begin{array}{l}\text { A estrutura vertical do edifício (pilares) } \\
\text { necessita de maior rigidez à ação das forças } \\
\text { horizontais (contraventamento), nas duas } \\
\text { direções ortogonais (longitudinal e transversal). } \\
\text { Este problema agrava-se com a divisão da torre }\end{array}$ & $01.1 .3 \mathrm{~B}$ & 1 \\
\hline
\end{tabular}




\begin{tabular}{|c|c|c|c|c|}
\hline & $\begin{array}{l}\text { em dois blocos isolados, separados por uma } \\
\text { junta de movimento. Estudos numéricos } \\
\text { demonstram também a necessidade de } \\
\text { consideração dos efeitos desfavoráveis devidos à } \\
\text { deslocabilidade da estrutura (efeitos de } 2^{a} \\
\text { ordem), na determinação dos esforços } \\
\text { solicitantes nos pilaresenas fundações. }\end{array}$ & & & \\
\hline 02 & $\begin{array}{l}\text { Os pilares P1-P2-P3-P4A, P4B-P5-P6-P7-P8, } \\
\text { P9-P10 e P16-P17 não estão devidamente } \\
\text { solidarizados entre si, do } 7{ }^{\circ} \text { teto para cima, no } \\
\text { plano longitudinal (direção do lado maior do } \\
\text { edifício), além de não possuírem rigidez neste } \\
\text { mesmo plano. Esta situação é particularmente } \\
\text { crítica nos pavimentos de números } 7,9,11,13 \text {, } \\
\text { 15, } 17 \text { e 19, pela presença de espaços abertos nas } \\
\text { lajes, em localizações desfavoráveis. }\end{array}$ & $\begin{array}{c}\text { 3, item } \\
5.1\end{array}$ & 51 & 1 \\
\hline 03 & $\begin{array}{l}\text { As lajes com } 11 \mathrm{~cm} \text { de espessura, dos } \\
\text { pavimentos de números } 6,8,10,12,14,16 \text { e } 18 \\
\text { apresentarão deformações exageradas em } \\
\text { serviço, capazes de induzir trincas nas paredes } \\
\text { que nelas seapoiam. }\end{array}$ & $\begin{array}{c}3, \text { item } \\
4.2 .3\end{array}$ & 45,51 & 1 \\
\hline 04 & $\begin{array}{l}\text { As vigas V801, V802, V801A e V802A } \\
\text { apresentarão deformações (flechas) exageradas } \\
\text { em serviço, capazes de provocar trincas } \\
\text { acentuadas nas paredes que suportam. }\end{array}$ & $\begin{array}{l}\text { 3, item } \\
4.2 .3\end{array}$ & 51 & 1 \\
\hline 05 & $\begin{array}{l}\text { As cintas das fachadas não têm segurança à } \\
\text { ruptura. }\end{array}$ & $\begin{array}{c}3 \text {, item } \\
5.1\end{array}$ & 51 & 1 \\
\hline 06 & $\begin{array}{l}\text { As deformações de pisos superpostos, que se } \\
\text { apoiam uns nos outros - como é o caso dos } \\
\text { pavimentos-tipo deste edifício - resultam em } \\
\text { acréscimos significativos das deformações dos } \\
\text { pisos dos andares mais baixos, pela transferência } \\
\text { progressiva de carga com o tempo, de cima para } \\
\text { baixo. Tal fato conduzirá a trincas ainda mais } \\
\text { acentuadas nas paredes dos pisos dos primeiros } \\
\text { andares. }\end{array}$ & $\begin{array}{c}3 \text {, item } \\
4.2 .3\end{array}$ & 51 & 1 \\
\hline 07 & $\begin{array}{l}\text { O grande balanço da fachada frontal, ao nível do } \\
\text { teto do play-ground (pav. 6), apresentará } \\
\text { deformações muito grandes (estimadas em } 24 \\
\mathrm{~cm} \pm 20 \% \text { ), difíceis de serem controladas por } \\
\text { contraflechas. }\end{array}$ & $\begin{array}{c}3, \text { item } \\
4.2 .3\end{array}$ & 45 & 1 \\
\hline 08 & $\begin{array}{l}\text { As vigas V602, V603, V } 606 \text { e V } 607 \text { apresentarão } \\
\text { deformações (flechas) exageradas em serviço, } \\
\text { capazes de provocar trincas acentuadas nas } \\
\text { paredes que suportam, além de incrementar as } \\
\text { deformações da própria laje de piso, que }\end{array}$ & $\begin{array}{l}\text { 3, item } \\
4.2 .3\end{array}$ & 45 & 1 \\
\hline
\end{tabular}




\begin{tabular}{|c|c|c|c|c|}
\hline & também suporta paredes. & & & \\
\hline 09 & $\begin{array}{l}\text { A taxa de armadura em alguns pilares, na região } \\
\text { das emendas das barras, apresenta valores } \\
\text { superiores a } 6 \% \text {. }\end{array}$ & $\begin{array}{l}\text { 3, item } \\
6.3 .1 .3\end{array}$ & 03 & 0 \\
\hline 10 & $\begin{array}{l}\text { Ausência de armadura transversal nas ligações } \\
\text { viga-pilar. }\end{array}$ & $\begin{array}{l}\text { 3, itens } \\
6.3 .1 .2 \\
6.3 .2 .4\end{array}$ & $\begin{array}{c}03 \text { a } 12, \\
15 \text { a } 18, \\
20 \text { a } 23, \\
25 \text { a } 29, \\
31 \text { a } 35, \\
38 \text { a } 44, \\
47 \text { a } 50, \\
53,54, \\
56,57, \\
60,61, \\
63\end{array}$ & 1 \\
\hline 11 & $\begin{array}{l}\text { Não há especificação do concreto nas plantas de } \\
\text { formas. }\end{array}$ & $\begin{array}{l}3, \text { item } \\
2.2\end{array}$ & $\begin{array}{l}36,45 \\
51,58\end{array}$ & 0 \\
\hline 12 & $\begin{array}{l}\text { Não foram previstos os espaços vazios junto às } \\
\text { caixas dos elevadores, nas plantas de formas dos } \\
\text { pavimentos de números } 7,9,11,13,15,17 \text { e } 19 \text {, } \\
\text { exigidos no projeto arquitetônico. }\end{array}$ & $\begin{array}{c}1, \\
\text { des.04 }\end{array}$ & 51 & 0 \\
\hline 13 & $\begin{array}{l}\text { A lgumas lajes de piso não dispõem de armadura } \\
\text { para resistir aos esforços de tração. }\end{array}$ & $\begin{array}{l}\text { 3, item } \\
6.3 .1\end{array}$ & $\begin{array}{l}46,52 \\
55,59\end{array}$ & 1 \\
\hline 14 & $\begin{array}{l}\text { Não foram previstas as posições das juntas de } \\
\text { concretagem e mata-juntas, nas paredes do } \\
\text { reservatório superior. }\end{array}$ & $\begin{array}{l}\text { 5, item } \\
2.8 .3\end{array}$ & 62 & 1 \\
\hline 15 & $\begin{array}{l}\text { As armaduras das paredes do reservatório } \\
\text { superior não garantem a segurança à fissuração, } \\
\text { com vistas à condição de estanqueidade. }\end{array}$ & $\begin{array}{l}\text { 4, item } \\
\quad 7.4\end{array}$ & 63 & 1 \\
\hline 16 & Omissão do projeto do reservatório inferior. & 1 & - & 1 \\
\hline
\end{tabular}

Quadro 5: DIVERG ÊNCIAS E OBSERVAÇÕES RELEVANTES

\begin{tabular}{|c|l|c|}
\hline$N^{\circ}$ & \multicolumn{1}{|c|}{ Identificação } & Des. nº \\
\hline 01 & $\begin{array}{l}\text { Nos desenhos de armadura não há indicação do } \\
\text { cobrimento das barras, conforme recomenda o projeto } \\
\text { de revisão da NB 16 (NBR 7191) - Execução de } \\
\text { desenhos para obras de concreto estrutural. }\end{array}$ & $\begin{array}{c}02,03 \text { a 12, 13, 14 a } \\
35,37 \text { a 44, 46 a 50, } \\
52 \text { a 57, 59 a 64. }\end{array}$ \\
\hline 02 & $\begin{array}{l}\text { Não há indicação das cotas dos pisos, nas plantas de } \\
\text { formas, conforme recomenda o projeto de revisão da } \\
\text { NB 16 (NBR 7191) - Execução de desenhos para obras } \\
\text { de concreto estrutural. }\end{array}$ & $\begin{array}{c}13,14,19,24,30,36, \\
45,51,58,62\end{array}$ \\
\hline
\end{tabular}




\begin{tabular}{|c|c|c|}
\hline 03 & $\begin{array}{l}\text { A inclinação da rampa da garagem não está indicada } \\
\text { na respectiva planta de formas. }\end{array}$ & 13 \\
\hline 04 & $\begin{array}{l}\text { Os apoios das vigas não estão identificados, nos } \\
\text { detalhes de armaduras das mesmas, conforme } \\
\text { recomenda o projeto de revisão da NB } 16 \text { (NBR 7191) } \\
\text { - Execução de desenhos para obras de concreto } \\
\text { estrutural. }\end{array}$ & $\begin{array}{c}13,15 \text { a } 18,20 \text { a } 23 \\
25 \text { a } 29,31 \text { a } 35,38 \text { a } \\
44,47 \text { a } 50,53,54 \\
56,57,60,61,63\end{array}$ \\
\hline 05 & $\begin{array}{l}\text { Os selantes das juntas de movimento não foram } \\
\text { especificados. }\end{array}$ & $\begin{array}{c}14,19,24,30,36,45 \\
51,58,62\end{array}$ \\
\hline 06 & $\begin{array}{l}\text { Não há indicação das escalas usadas nos detalhes e } \\
\text { cortes, conforme recomenda o projeto de revisão da } \\
\text { NB } 16 \text { (NBR 7191) - Execução de desenhos para obras } \\
\text { de concreto estrutural. }\end{array}$ & $\begin{array}{l}36,45,46,52,55,58, \\
59,62\end{array}$ \\
\hline 07 & $\begin{array}{l}\text { Faltam os detalhes dos aparel hos de apoio, nos } \\
\text { consolos da junta de movimento, no } 5^{\circ} \text { pavimento. }\end{array}$ & 36 \\
\hline 08 & $\begin{array}{l}\text { Recomenda-se aumentar a espessura da tampa do } \\
\text { reservatório de } 8 \mathrm{~cm} \text { para } 10 \mathrm{~cm} \text {, para compatibilizar } \\
\text { com o cobrimento de } 30 \mathrm{~mm} \text {. }\end{array}$ & 62 \\
\hline 09 & $\begin{array}{l}\text { Prever aberturas para inspeção na tampa do } \\
\text { reservatório superior. }\end{array}$ & 62 \\
\hline 10 & $\begin{array}{l}\text { Recomenda-se observar as recomendações de } \\
\text { desenho anotadas. }\end{array}$ & $\begin{array}{c}14,19,24,30,36,45 \\
51,58,62\end{array}$ \\
\hline 11 & $\begin{array}{l}\text { Recomenda-se aumentar os valores de cobrimento } \\
\text { adotados, conforme sugestões indicadas nos } \\
\text { desenhos. }\end{array}$ & $\begin{array}{l}02,03 \text { a } 12,13,14 \text { a } \\
35,37 \text { a } 44,46 \text { a } 50 \\
56 \text { a } 57,59 \text { a } 64\end{array}$ \\
\hline
\end{tabular}

\section{CONCLUSÕES}

A tendimento às exigências da qualidade prefixadas:

\section{Quadro 6: QUALIDADE DA SOLUÇÃO ADOTADA SOB AS CONDIÇÕES IM POSTAS AO PROJETO}

\begin{tabular}{|c|c|c|c|}
\hline \multicolumn{1}{|c|}{ Discriminação } & SIM & NÃO & $\begin{array}{c}\text { NÃO } \\
\text { VERIF. }\end{array}$ \\
\hline $\begin{array}{l}\text { 1. As condições arquitetônicas foram atendidas? } \\
\text { Ver Quadro 4, N-C nOS } 12 \text { e } 16 .\end{array}$ & & $X$ & \\
\hline $\begin{array}{l}\text { 2. As condições funcionais foram atendidas? } \\
\text { Ver Quadro 4, N-C nOS 01 a 04, 06 a 08, 14 e 15. }\end{array}$ & & $X$ & \\
\hline
\end{tabular}




\begin{tabular}{|l|c|c|c|}
\hline 3. As condições construtivas foram atendidas? & $\mathrm{X}$ & & \\
\hline $\begin{array}{l}\text { 4. As condições estruturais foram atendidas? } \\
\text { Ver Quadro 4, N-C nos 01 a 08 e 10. }\end{array}$ & & $\mathrm{X}$ & \\
\hline $\begin{array}{l}\text { 5. As condições de integração com os demais projetos } \\
\text { foram atendidas? }\end{array}$ & & $\mathrm{X}$ \\
\hline 6. As condições econômicas foram atendidas? & & & $\mathrm{X}$ \\
\hline
\end{tabular}

Quadro 7: QUALIDADE DO PROJETO SOB AS EXIGÊNCIAS DAS NORMAS TÉCNICAS DE CÁLCULO

\begin{tabular}{|l|c|c|c|}
\hline \multicolumn{1}{|c|}{ Discriminação } & SIM & NÃO & $\begin{array}{c}\text { NÃO } \\
\text { VERIF. }\end{array}$ \\
\hline $\begin{array}{l}\text { 1. As condições de segurança contra ruptura foram } \\
\text { atendidas? } \\
\text { Ver Quadro 4, N-C nos 01, 02, 05, 10 e 13. }\end{array}$ & X & X & \\
\hline $\begin{array}{l}\text { 2. As condições de segurança contra deformações } \\
\text { excessivas foram atendidas? } \\
\text { Ver Quadro 4, N-C n0s 03, 04, 06, 07 e 08. }\end{array}$ & $\mathrm{X}$ & $\mathrm{X}$ \\
\hline $\begin{array}{l}\text { 3. As condições de segurança contra fissuração } \\
\text { excessiva foram atendidas? }\end{array}$ & & $\mathrm{X}$ & \\
\hline $\begin{array}{l}\text { Ver Quadro 4, N-C no 15. } \\
\text { As exigências de durabilidade foram atendidas? }\end{array}$ & & \\
\hline $\begin{array}{l}\text { 5. As exigências de estanqueidade foram atendidas? } \\
\text { Ver Quadro 4, N-C nos 14 e 15. }\end{array}$ & & \\
\hline
\end{tabular}

Fim do Relatório Conclusivo

\subsection{RESERVATÓRIO CILÍNDRICO}

O segundo exemplo a ser apresentado consiste no controle da qualidade do projeto estrutural de um reservatório apoiado no solo, com capacidade de, aproximadamente, $300 \mathrm{~m}^{3}$. O reservatório tem forma cilíndrica em planta, com $10 \mathrm{~m}$ de diâmetro interno e 4,55 m de altura. Além da parede, quatro pilares centrais, com seção transversal quadrada de $20 \mathrm{~cm}$ de lado, servem de apoio para a laje da tampa. 
Na Figura 5.5 mostra-se, esquematicamente, um corte vertical do reservatório e indicam-se dados referentes às especificações dos materiais. Maiores informações sobre as características do reservatório ora analisado podem ser vistas no relatório conclusivo apresentado adiante.

Por ser um reservatório de dimensões relativamente grandes, a empresa construtora, temendo a possibilidade de fissuração excessiva na parede e na laje do fundo, que pudesse comprometer a funcionalidade da estrutura, decidiu submeter o projeto estrutural do referido reservatório ao controle da qualidade, de modo a propiciar condições para que eventuais falhas fossem corrigidas ainda no projeto, antes da execução propriamente dita.

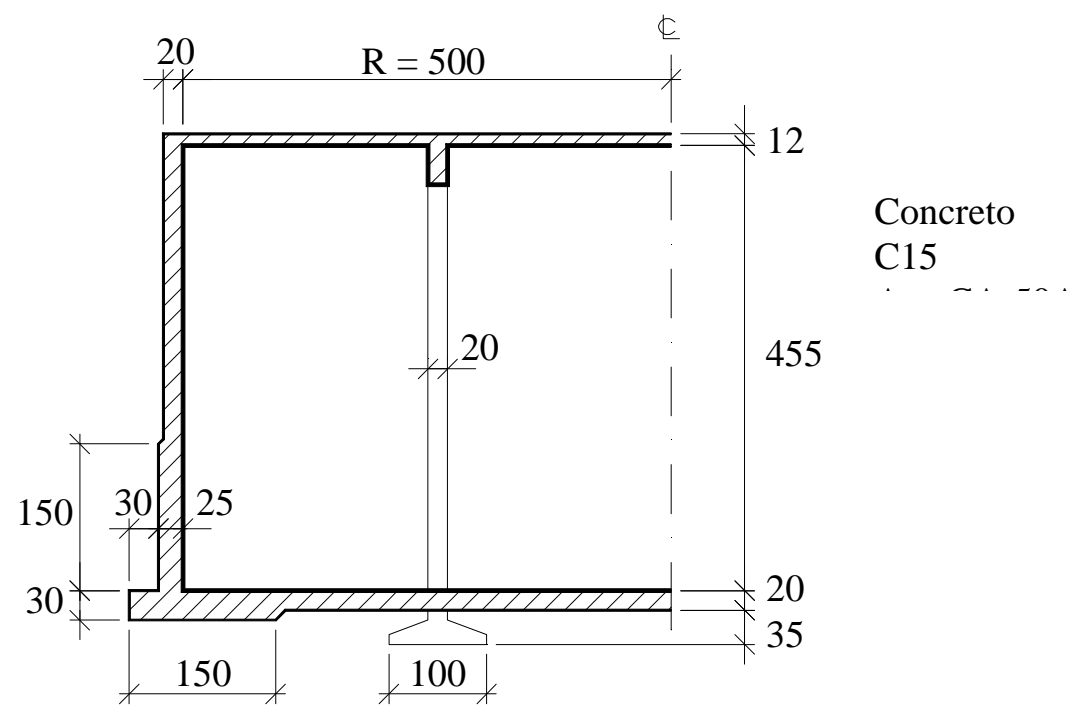

Figura 5.5 - Corte vertical do reservatório cilíndrico apoiado (desenho esquemático).

Seguindo a metodologia proposta, inicialmente, identificaram-se todos os documentos que serviriam de referência para o controle da qualidade do projeto e, em seguida, realizaram-se as verificações necessárias para avaliar a segurança, o bom desempenho em serviço e a durabilidade da estrutura. Neste caso, assim como no primeiro exemplo, não se dispunha da memória de cálculo e, portanto, o procedimento adotado consistiu na comparação dos resultados dos cálculos efetuados pelo controle da qualidade com as informações constantes dos desenhos do projeto. 
Da análise efetuada, verificou-se que a segurança com relação aos estados limites últimos foi satisfatoriamente atendida, ao passo que alguns aspectos relacionados ao estado limite de fissuração excessiva, preocupação inicial da empresa responsável pela construção, e outros relativos à durabilidade, precisaram ser revistos pelo projetista.

Os resultados do controle da qualidade encontram-se sintetizados no relatório conclusivo a seguir apresentado, tendo sido excluída, por conveniência, a memória de cálculo das verificações efetuadas. Pode-se observar que este relatório utiliza um modelo diferente daquele apresentado no exemplo anterior. Não é seguida a metodologia proposta, no que diz respeito à classificação das informações do projeto em não-conformidade e divergência (ver item 2.3.3), entretanto, o relatório alerta sobre pontos críticos do projeto, apontando sugestões e recomendações que visam exclusivamente a sua melhoria. Observem ainda que foram eliminados os quadros $6 \mathrm{e}$ 7 do modelo usado no exemplo anterior, os quais, conforme já se disse, não fornecem uma boa indicação a respeito da qualidade do projeto, como um todo.

\section{Relatório do}

\section{CONTROLE DA QUALIDADE DO PROJETO ESTRUTURAL DO RESERVATÓRIO APOIADO $\left(300 \mathrm{~m}^{3}\right)$}

A presentam-se, a seguir, os resultados do controle da qualidade do projeto estrutural do reservatório apoiado, com capacidade de, aproximadamente, $300 \mathrm{~m}^{3}$. Para a análise do projeto, serviram de referência os seguintes documentos:

- N ormas técnicas atualizadas: NBR 6118 (1978), CEB-FIP Model Code 1990 (1991), EUROCODE 2 (1992), DIN 1045 (1989);

$\Rightarrow$ Desenhos do projeto estrutural: $\quad$ IPB-30-5-001 - Rev.0 - 28/ 02/ 92;

IPB-30-5-002 - Rev.0 - 28/ 02/ 92;

IPB-30-5-003 - Rev.0 - 28/ 02/ 92. 
Esta análise extrapola, possivelmente, os limites inicialmente fixados, movida pelo desejo de contribuir com sugestões para a melhoria e aperfeiçoamento do projeto citado. De fato, a solicitação inicial de serviços relativos ao controle da qualidade deste projeto refere-se apenas à preocupação com a segurança à fissuração da parede e da laje do fundo, com vistas à garantia de estanqueidade do reservatório. Extrapolando estes limites, a análise que se segue estende-se na apreciação de outros aspectos relevantes do projeto, que vão desde as especificações dos materiais aos aspectos de durabilidade e detal hes de armadura.

As observações que compõem esta análise não têm, nem de leve, a intenção de expressar um juízo de valor sobre o projeto ou sobre a indiscutível competência de seus autores, mas sim, conforme já se disse, o desejo de contribuir para a melhoria e aperfeiçoamento do mesmo, em função da longa experiência profissional deste autor em projetos e anál ise de projetos de reservatórios.

Pede-se, pelo exposto, que desconsidere as sugestões que julgar descabidas para os fins em vista, extraindo deste Relato apenas as sugestões que achar pertinentes.

\section{DESCRIÇÃO SUMÁRIA}

Trata-se de um reservatório cilíndrico, de concreto armado, apoiado diretamente no solo de fundação, com 10 m de diâmetro interno e 4,55 m de altura. O projeto não esclarece se o reservatório tem implantação superficial ou se é semienterrado.

A laje do fundo tem espessura de $20 \mathrm{~cm}$, na região central, e de $30 \mathrm{~cm}$ sob a parede. A parede tem $25 \mathrm{~cm}$ de espessura, da base até a altura de 1,5 m, onde se reduz a $20 \mathrm{~cm}$, até a tampa. Esta, por sua vez, com $12 \mathrm{~cm}$ de espessura, apoia-se, simultaneamente, na parede e em quatro pilares centrais. 


\section{SUGESTÕES}

\section{ESPECIFICAÇÕES}

1 - Sugere-se que o concreto a ser usado tenha especificação mais detal hada do que a do projeto. De fato, o projeto, no Desenho IPB-30-5-003, registra a especificação do concreto: " $\mathrm{f}_{\mathrm{ck}}=150 \mathrm{kgf} / \mathrm{cm}^{2}$ ", ou seja, C15 ( $\left.\mathrm{f}_{\mathrm{ck}}=15 \mathrm{MPa}\right)$, enquanto que se sugere, não apenas elevar a resistência para C25 (pelo menos), mas também caracterizar melhor o material que se julga necessário, tendo em vista sua finalidade, como se discrimina a seguir:

$\Rightarrow$ Resistência:

- Teor mínimo de cimento: $350 \mathrm{~kg} / \mathrm{m}^{3}$

$\Rightarrow$ Relação água-cimento: $\quad$ 0,50

2 - Recomenda-se que o cobrimento das armaduras, em todas as peças, seja de, pelo menos, $30 \mathrm{~mm}$, por exigência de Norma para peças em contato com solos e águas não-agressivas. O valor mais apropriado seria de $40 \mathrm{~mm}$, conforme recomendam as normas técnicas mais atualizadas, para estruturas hidráulicas. $O$ projeto não especifica, explicitamente, o cobrimento a adotar, deixando entretanto perceber, em alguns detalhes de armadura, que o cobrimento desejado é de apenas $25 \mathrm{~mm}$.

\section{FUNDAÇÕES}

1 - Sugere-se que a fundação do pilar, em vez de ser abaixo da laje do fundo, repouse nesta, conforme esclarece a Figura 5.6. Realmente, estando o pilar solidário com a laje do fundo, as cargas nele atuante mobilizarão reações no solo, tanto sob a sapata como sob a própria laje do fundo. Portanto, já que a sapata e a laje do fundo são ambas fundação do pilar, implantadas no mesmo solo de fundação, separá-las em níveis diferentes significa acrescentar dificuldades construtivas, injustificadamente. 

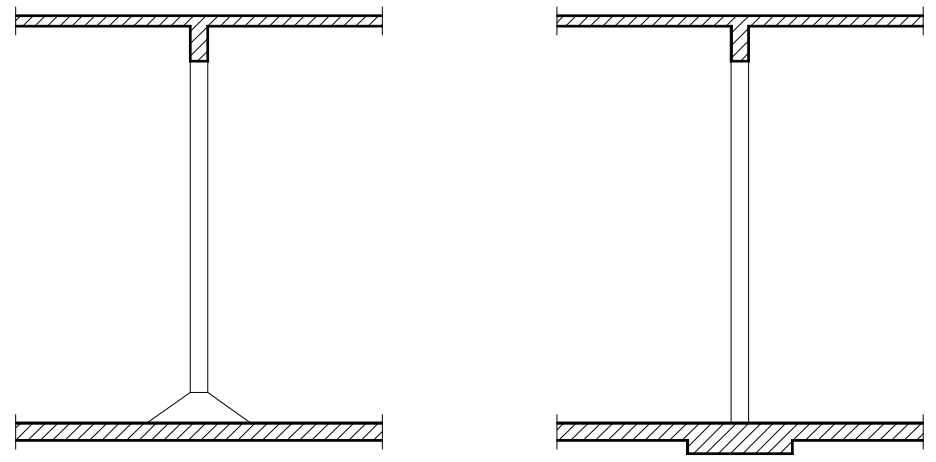

Figura 5.6 - Alternativas de fundação para o pilar solidário com a laje do fundo.

2 - Sugere-se que o bordo da laje de fundação seja chanfrado, a fim de evitar o canto desfavorável, onde se concentram umidade e sujeira, de modo prejudicial à durabilidade da peça de concreto. A Figura 5.7 ilustra o que se sugere.

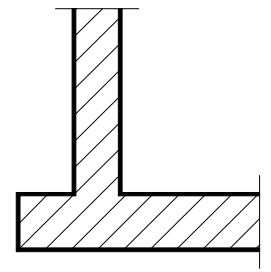

Projeto

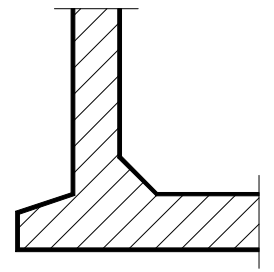

Sugestão

Figura 5.7 - O chanfro no bordo da laje de fundação favorece a durabilidade.

\section{LAJE DO FUNDO}

1 - Recomenda-se que as armaduras previstas para a laje do fundo, de $\phi 10 \mathrm{c} .15 \mathrm{~cm}$ e $\phi 8 c .15 \mathrm{~cm}$, sejam substituídas por $\phi 10 \mathrm{c} .10 \mathrm{~cm}$, para melhor controle da fissuração. Esta armadura (mínima) resulta da hipótese de que esta fissuração pode se estabelecer na fase do reservatório ainda vazio, sob os efeitos das deformações impostas por retração e temperatura. Utilizou-se como referência, para cálculo desta armadura mínima, o Código Modelo CEB-FIP Model Code 1990 (1991), seção 7.4, arbitrando-se a abertura limite das fissuras igual a 0,15 mm, para satisfazer à condição de estanqueidade. A utilização de outras normas atualizadas, como a DIN 1045 (1989) ou a EUROCODE 2 (1992), conduziria à mesma armadura mínima acima indicada. As normas brasileiras, como a NBR 6118 (1978), ainda não 
incorporaram a seu texto estas novas exigências restritivas, justificadas largamente pela observação freqüente de tais fissurações inconvenientes em reservatórios executados.

2 - A incorporação das fundações dos pilares à laje do fundo exigirá acréscimos das armaduras desta laje, na região de apoio dos pilares.

3- Sugerem-se modificações no detalhamento da armadura na região de ligação entre parede e laje de fundo. Tais modificações, indicadas na Figura 5.8, proporcionam vantagens nas operações de dobramento, assentamento e concretagem.

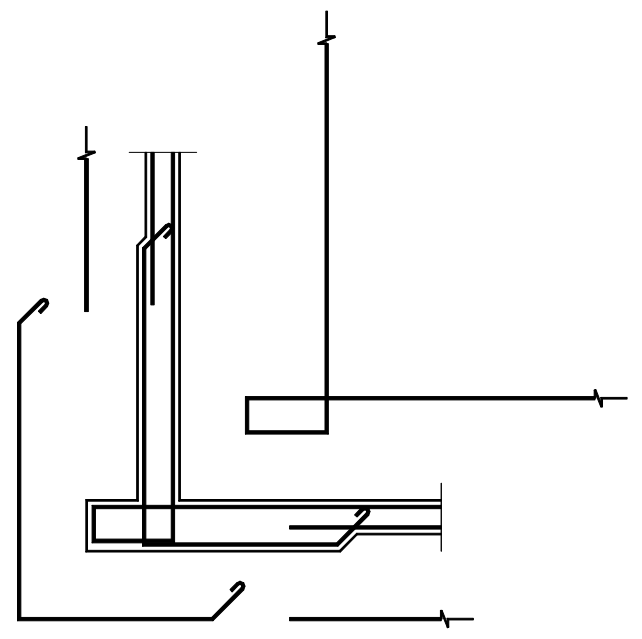

Projeto

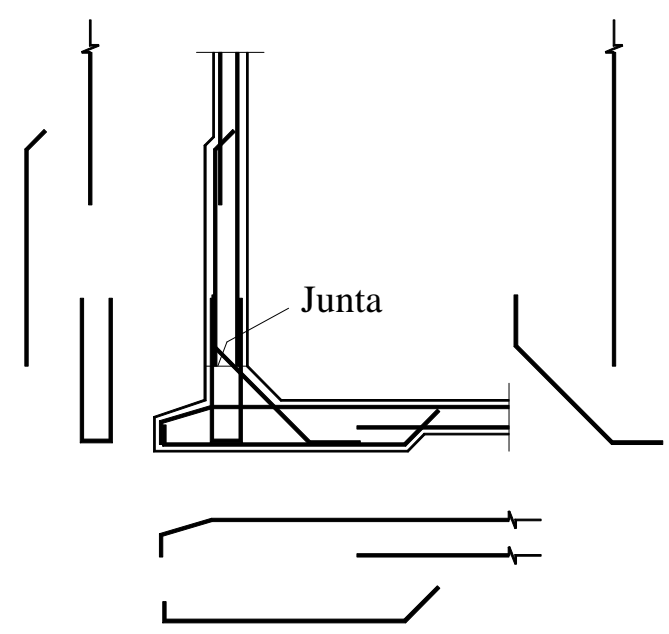

Sugestão

Figura 5.8 - Sugestão para armaduras na ligação da parede com a laje de fundo.

\section{PAREDE}

1 - Sugere-se que seja considerada a possibilidade de fazer a parede com espessura constante, da laje do fundo à tampa. Realmente, o engrossamento da parede, próximo à sua base, previsto no projeto, representa uma dificuldade construtiva que se pode evitar. No caso de opção por fôrmas deslizantes, por exemplo, este engrossamento éindesejável. 
2 - Recomenda-se que sejam indicadas as posições das juntas horizontais de concretagem da parede, pela sua influência na estanqueidade da mesma, prevendose a colocação de mata-juntas rígidos nestas juntas. Estes mata-juntas seriam constituídos de chapas de aço de pequena espessura, com $15 \mathrm{~cm}$ de largura, emendadas por solda e dispostas nas juntas, conforme esclarece a Figura 5.9.

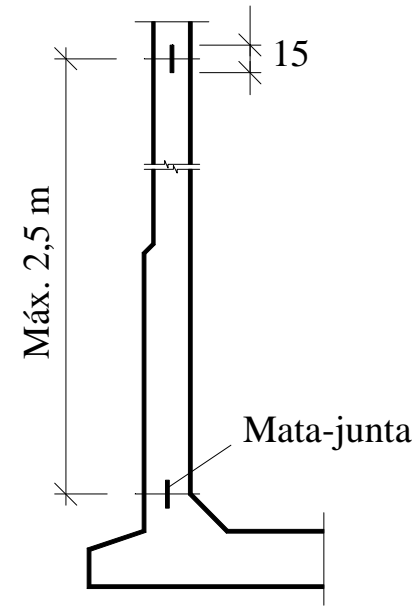

Figura 5.9 - Prever a posição das juntas e seus respectivos mata-juntas.

3- Recomenda-se aumentar as armaduras horizontais das paredes, para melhor controle da fissuração. A armadura de $\phi 10 \mathrm{c} .15 \mathrm{~cm}$ (parede com $25 \mathrm{~cm}$ de espessura) seria aumentada para $\phi 10 \mathrm{c} .8 \mathrm{~cm}$, enquanto que a armadura horizontal de $\phi 8 \mathrm{c} .15 \mathrm{~cm}$ (parede com $20 \mathrm{~cm}$ de espessura) seria aumentada para $\phi 8 \mathrm{c} .7 \mathrm{~cm}$ (ou $\phi 10 \mathrm{c} .10 \mathrm{~cm}$ ). Esta armadura mínima recomendada pretende controlar a fissuração, com vistas à condição de estanqueidade, sob os efeitos das restrições impostas às deformações da parede sob a ação da retração e da temperatura (hipótese de reservatório vazio). Para cálculo desta armadura, utilizou-se o Código Modelo CEB-FIP Model Code 1990 (1991), seção 7.4, arbitrando-se a abertura limite das fissuras igual a 0,15 mm, para satisfazer à condição de estanqueidade. 
4 - Sugere-se aumentar o diâmetro das barras verticais da parede de $\phi 8$ para, pelo menos, $\phi 10 \mathrm{~mm}$, pela necessidade de maior rigidez destas barras, para melhor sustentação do feixe de armadura.

5 - Evitar o uso de ganchos nas barras verticais da parede, conforme exigência de normas (ver, por exemplo, NBR 6118, 1978, item 6.3.4.1).

\section{TAMPA}

1 - Recomenda-se que seja prevista a drenagem das águas pluviais na tampa do reservatório. Apresentam-se na Figura 5.10, como ilustração, duas soluções que podem ser adotadas.
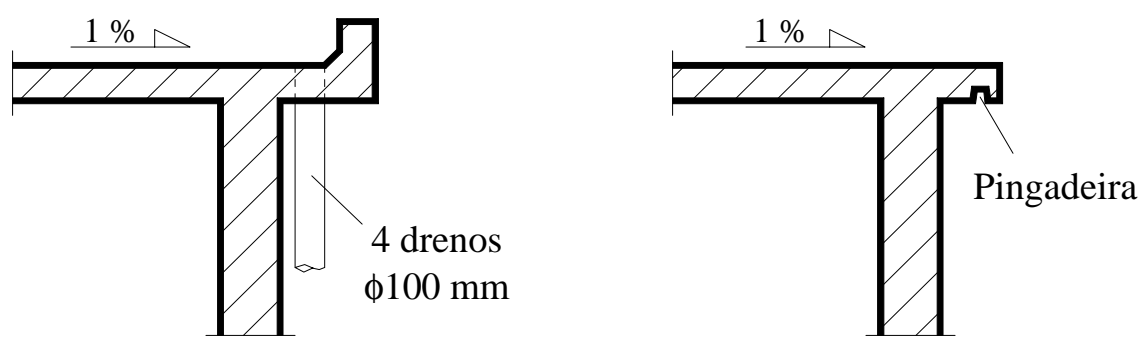

Figura 5.10 - Alternativas de drenagem da tampa do reservatório.

\section{PILARES}

1 - Recomenda-se que os pilares tenham seção de, pelo menos $25 \mathrm{~cm} \times 25 \mathrm{~cm}$, com vistas à sua melhor rigidez, dada a sua altura livre de mais de 4,5 m. Estas dimensões permitem, inclusive, considerar a possibilidade vantajosa de pré-moldar os pilares, horizontalmente, sobre a própria laje do fundo, para depois içá-los em posição vertical. O projeto pode, inclusive, escolher a alternativa de usar apenas um pilar central, octogonal, com $\phi 35 \mathrm{~cm}$, sem necessidade de aumentar a espessura da tampa, de $12 \mathrm{~cm}$, conforme indicado na Figura 5.11. 


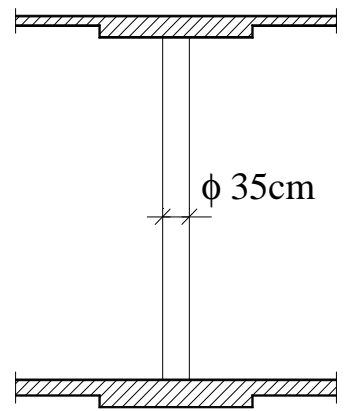

Figura 5.11 - Alternativa de adotar um único pilar central.

Fim do Relatório Conclusivo 


\section{CONSIDERAÇÕES FINAIS}

Diversos estudos sobre os problemas relacionados à qualidade e à durabilidade das estruturas de concreto armado apontam os erros de projeto como uma das principais causas das patologias detectadas, juntamente com a utilização de materiais inadequados. Acrescente-se o fato de que muitos erros cometidos na execução das estruturas poderiam ser evitados se houvesse mais especificações de projeto.

Uma das formas encontradas para assegurar um bom nível de desempenho das estruturas consiste na melhoria da qualidade dos respectivos projetos estruturais, seja pela implantação de um sistema de garantia da qualidade desses projetos ou mediante a elaboração de especificações apropriadas.

Estes aspectos foram minuciosamente abordados ao longo deste trabalho, do qual se extraem as seguintes considerações finais:

1. O projeto é uma peça fundamental, senão a mais importante, na busca pela racionalização do processo construtivo, exercendo influência decisiva na qualidade do produto final, aqui representado pelas estruturas de concreto armado. Controlar a sua qualidade é, portanto, essencial para prevenir a ocorrência de erros e, conseqüentemente, afastar os riscos de mau comportamento das estruturas em serviço. Deve ser dada ao projeto uma importância muito maior do que a que ele recebe hoje, pois a partir dele pode-se obter uma economia significativa na obra.

2. O controle da qualidade de projetos estruturais é uma atividade que, lentamente, começa a ser incorporada ao setor construtivo, a exemplo do que ocorre na Europa e nos Estados Unidos. Seu principal propósito é assegurar uma qualidade aceitável 
do projeto, através da detecção oportuna de eventuais falhas que possam comprometer a segurança e a durabilidade das estruturas.

3. As diretrizes básicas apresentadas no Capítulo 2, para o controle da qualidade de projetos estruturais, constituem medidas mínimas essenciais para a verificação de projetos. Tais diretrizes não devem ser tomadas como regras rígidas, devendo cada profissional utilizar os parâmetros fornecidos conforme sua conveniência.

4. Todas as pessoas envolvidas no processo construtivo devem ter um mínimo de conhecimento sobre os mais importantes mecanismos de deterioração do concreto, os parâmetros que os governam e as formas de combatê-los, tal como destrinchado no Capítulo 3. Este conhecimento forma a base para a preparação de especificações adequadas, tendo em vista a durabilidade das estruturas.

5. A evolução da tecnologia dos materiais tem conduzido a um aumento significativo das resistências empregadas, possibilitando a utilização de elementos estruturais com seções cada vez mais delgadas. Com isso, torna-se imprescindível que seja direcionada maior atenção aos aspectos da durabilidade, uma vez que peças mais esbeltas são também mais vulneráveis às influências ambientais.

6. O critério de aceitação das estruturas, baseado unicamente na resistência do concreto, tem-se mostrado um tanto inadequado, pois, na verdade, a durabilidade está muito mais relacionada à permeabilidade do concreto do que à sua resistência.

7. Desta forma, deve-se abandonar esta filosofia tradicional de considerar apenas a segurança como fator importante, deixando a durabilidade em segundo plano. Deve-se aumentar a preocupação com a durabilidade e direcionar maiores esforços no desenvolvimento e na aplicação de critérios de projeto, como os que foram apresentados no Capítulo 4.

8. Dos exemplos apresentados, constata-se a importância do controle da qualidade, não só no aperfeiçoamento do projeto, como no exemplo 2, mas também, e principalmente, na detecção de falhas graves, como é o caso do exemplo 1. Em ambos os exemplos, os resultados efetivos do controle traduziram-se em significativa melhoria da qualidade das estruturas concebidas. 
De todo o exposto, espera-se que este trabalho sirva como um alerta para o meio técnico, com relação à necessidade de melhorar o desempenho das construções.

Aos projetistas, cabe a tarefa de providenciar para que o projeto seja elaborado de forma mais cuidadosa e detalhada, contendo especificações apropriadas e completas, principalmente com relação aos materiais a serem empregados, tendo em vista a durabilidade das estruturas nas condições de exposição previstas. Tem-se observado que, em geral, os requisitos de segurança são satisfatoriamente atendidos, ao passo que as exigências de bom desempenho em serviço e de durabilidade são, muitas vezes, deixadas em segundo plano.

Aos construtores, recomenda-se que estejam mais atentos aos procedimentos apropriados para execução do concreto, principalmente com relação às atividades de lançamento, adensamento e cura. Ainda com relação aos construtores, que, em geral, são os contratantes de projetos estruturais, fica o alerta para a conscientização de que devem ser dadas aos projetistas condições adequadas - referentes a preço e, principalmente, prazo -, para que possam desenvolver seus projetos, buscando sempre a melhor solução estrutural e, também, a otimização do processo construtivo.

Por fim, vale ressaltar que hoje já se dispõe de conhecimento suficiente para projetar, especificar e construir estruturas duráveis de concreto, que sejam capazes de resistir às influências ambientais, sem apresentar degradação excessiva durante um determinado período de tempo. O que falta, no momento, é a aceitação e a aplicação inteligente do conhecimento disponível e recentemente desenvolvido.

De fato, a durabilidade do concreto armado é um assunto já bastante explorado por diversos pesquisadores. Assim, como continuidade a este trabalho, recomenda-se um estudo mais aprofundado sobre a qualidade na Construção Civil, tema relativamente recente, especialmente na área de projetos. Este estudo poderia envolver a aplicação das técnicas do controle da qualidade de projetos a outros tipos de estruturas, como as pontes, por exemplo, e a criação de um modelo padrão para a apresentação do relatório conclusivo. 


\section{REFERÊNCIAS BIBLIOGRÁFICAS}

AMERICAN CONCRETE INSTITUTE (1985). ACI 121R-85: Quality assurance systems for concrete construction. Detroit, Michigan.

AMERICAN CONCRETE INSTITUTE (1992). ACI 201.2R-92: Guide to durable concrete. Detroit, Michigan.

ASSOCIAÇÃO BRASILEIRA DE NORMAS TÉCNICAS (1978). NBR 6118 Projeto e execução de obras de concreto armado. Rio de Janeiro. 76p.

ASSOCIAÇÃO BRASILEIRA DE NORMAS TÉCNICAS (1991). NBR 11578 Cimento Portland composto. Rio de Janeiro. 5p.

ASSOCIAÇÃO BRASILEIRA DE NORMAS TÉCNICAS (1991). NBR 5732 Cimento Portland comum. Rio de Janeiro. 5p.

ASSOCIAÇÃO BRASILEIRA DE NORMAS TÉCNICAS (1991). NBR 5733 Cimento Portland de alta resistência inicial. Rio de Janeiro. 5p.

ASSOCIAÇÃO BRASILEIRA DE NORMAS TÉCNICAS (1991). NBR 5735 Cimento Portland de alto forno. Rio de Janeiro. 5p.

ASSOCIAÇÃO BRASILEIRA DE NORMAS TÉCNICAS (1991). NBR 5736 Cimento Portland pozolânico. Rio de Janeiro. 5p.

ASSOCIAÇÃO BRASILEIRA DE NORMAS TÉCNICAS (1994). NBR ISO 8402 Gestão da qualidade e garantia da qualidade: terminologia. Rio de Janeiro. 15p. ASSOCIAÇÃO BRASILEIRA DE NORMAS TÉCNICAS (1994). Revisão da NB 1. Rio de Janeiro. 
COMITÉ EURO-INTERNATIONAL DU BÉTON (1993). CEB-FIP model code 1990: design code. CEB Bulletin d'Information, n.213/214.

COMITÉ EURO-INTERNATIONAL DU BÉTON (1989). Durable concrete structures: CEB design guide. 2.ed. CEB Bulletin d'Information, n.182.

COMITÉ EURO-INTERNATIONAL DU BÉTON (1988). Quality assurance for buildings: synthesis report. CEB Bulletin d'Information, n.184.

COMITÉ EURO-INTERNATIONAL DU BÉTON (1983). Quality control and quality assurance for concrete structures. CEB Bulletin d'Information, n.157.

EUROCODE 2 (1992). Design of concrete structures - Part I: General rules and rules for buildings. Brussels, CEN.

JOINT COMMITTEE ON STRUCTURAL SAFETY (1981). General principles on quality assurance for structures. Lisboa, Portugal.

JURAN, J.M.; GRYNA, F.M. (1980). Quality planning and analysis. 2.ed. USA, McGraw-Hill, Inc. Cap.1.

KAZMIERCZAK, C.S.; HELENE, P.R.L. (1993). Análise de fatores que influenciam a velocidade de carbonatação em estruturas de concreto armado. In: REUNIÃO DO IBRACON, 35., Brasília, 1993. Anais. São Paulo, Ibracon. v.2, p.627-640.

LARANJEIRAS, A.C.R. (1993). Garantia de qualidade dos projetos. In: SIMPÓSIO EPUSP SOBRE ESTRUTURAS DE CONCRETO, 3., São Paulo, 1993. Anais. São Paulo, EPUSP/PEF. p.49-61.

MATHER, K.; MATHER, B. (1987). Reflections on concrete durability and on international conferences on concrete durability. In: KATHARINE AND BRYANT MATHER INTERNATIONAL CONFERENCE ON CONCRETE DURABILITY, Atlanta, USA, 1987. Detroit, ACI. v.1, p.1-5. (ACI SP 100).

NEVILLE, A.M. (1982). Propriedades do concreto. Trad. por Salvador E. Giammusso. São Paulo, Pini. Cap.7, p.412-502.

PALADINI, E.P. (1990). Controle de qualidade: uma abordagem abrangente. São Paulo, Atlas S.A. Cap.1, 2, 5. 
PAULON, V.A. (1986). Durabilidade dos concretos. In: SEMINÁRIO NORDESTINO SOBRE TECNOLOGIA DO CONCRETO, 2., Fortaleza, 19-21 de novembro de 1986. Anais. Fortaleza, 1986. Paginação irregular.

SINHA, M.N.; WILLBORN, W.O. (1985). The management of quality assurance. New York, USA, John Wiley \& Sons. Cap.1, 2, 8.

SKALNY, J. (1987). Concrete durability - an issue of national importance. In: KATHARINE AND BRYANT MATHER INTERNATIONAL CONFERENCE ON CONCRETE DURABILITY, Atlanta, USA, 1987. Detroit, ACI. v.1, p.265279. (ACI SP 100).

SOUZA, M.T. (1991). Clínica geral. Erros de projeto, execução, materiais, uso. Vale tudo. Construção São Paulo, ano XLIV, n.2277, p.4-8, set.

WADSWORTH, H.M.; STEPHENS, K.S.; GODFREY, A.B. (1986). Modern method for quality control and improvement. New York, USA, John Wiley \& Sons. Cap.1, 2. 


\section{BIBLIOGRAFIA COMPLEMENTAR}

ACI COMMITTEE 222 (1985). Corrosion of metals in concrete. Concrete International, v.7, n.9, p.56-59, Sept.

ASSOCIAÇÃO BRASILEIRA DE NORMAS TÉCNICAS (1994). NBR ISO 9001 -

Sistemas da qualidade: modelo para garantia da qualidade em projeto, desenvolvimento, produção, instalação e serviços associados. Rio de Janeiro. $11 \mathrm{p}$.

BEEBY, A.W. (1983). Cracking, cover, and corrosion of reinforcement. Concrete International, v.5, n.2, p.35-40, Feb.

COELHO FILHO, J.S. (1996). Os caminhos para a qualidade da construção. ABECE Informa, São Paulo, Entrevista, maio/96, ano 1, n.4, p.3-5.

CORROSION OF REINFORCEMENT IN CONCRETE - 12-CRC COMMITTEE. (1976). Corrosion of reinforcement and prestressing tendons. A state of the art report. Materials and Constructions, v.9, n.51, p.187-206, May/June.

FERREIRA, E.A.M. (1991). Diretrizes para garantia da qualidade em construções industrializadas: uma aplicação à tecnologia da argamassa armada. São Carlos. 164p. Dissertação (Mestrado) - Escola de Engenharia de São Carlos, Universidade de São Paulo.

FRANÇA, R.L.S. (1996). Nova NB-1 integra elementos construtivos. Engenharia \& Consultoria Estrutural, São Paulo, As melhores do ano, outubro/96, ano 0, n.0. p.23.

GIAMMUSSO, S.E. (1991). Concreto e cloretos. Construção São Paulo, ano XLIV, n.2275, p.25-28, set. 
HELENE, P.R.L. (1993). Durabilidade das estruturas de concreto armado. In: SIMPÓSIO EPUSP SOBRE ESTRUTURAS DE CONCRETO, 3., São Paulo, 1993. Anais. São Paulo, EPUSP/PEF. p.37-48.

MacGREGOR, J.G. (1992). Reinforced concrete: mechanics and design. 2.ed. Englewood Cliffs, New Jersey, Prentice Hall. Cap.3, p.35-72.

MEYER, A. (1987). The importance of the surface layer for the durability of concrete structures. In: KATHARINE AND BRYANT MATHER INTERNATIONAL CONFERENCE ON CONCRETE DURABILITY, Atlanta, USA, 1987. Detroit, ACI. v.1, p.49-61. (ACI SP 100).

NEVILLE, A. (1987). Why we have concrete durability problems. In: KATHARINE AND BRYANT MATHER INTERNATIONAL CONFERENCE ON CONCRETE DURABILITY, Atlanta, USA, 1987. Detroit, ACI. v.1, p.21-30. (ACI SP 100).

OLIVEIRA, P.S.F.; HELENE, P.R.L. (1991). Proteção e manutenção das estruturas de concreto. Engenharia, n.485, p.11-26, nov/dez.

POPOVICS, S. (1987). A classification of the deterioration of concrete based on mechanism. In: KATHARINE AND BRYANT MATHER INTERNATIONAL CONFERENCE ON CONCRETE DURABILITY, Atlanta, USA, 1987. Detroit, ACI. v.1, p.131-142. (ACI SP 100).

POTTER, R.; HO, D. (1987). Quality of cover concrete and its influence on durability. In: KATHARINE AND BRYANT MATHER INTERNATIONAL CONFERENCE ON CONCRETE DURABILITY, Atlanta, USA, 1987. Detroit, ACI. v.1, p.423-445. (ACI SP 100).

ROSTAM, S. (1991). Durability of concrete structures: the CEB-FIP approach. In: COLLOQUIUM ON THE CEB-FIP MODEL CODE 90, August, 1991. Rio de Janeiro, COPPE-UFRJ/CEB. p.369-429.

SLATER, J.E. (1979). Corrosion of reinforcing steel in concrete: magnitude of the problem. Materials Performance, v.18, n.6, p.34-37, June. 
VASCONCELOS, A.C. (1996). Engenharia não é ciência exata. Engenharia \& Consultoria Estrutural, São Paulo, As melhores do ano, outubro/96, ano 0, n.0, p.21-22.

VELLETRI, M.M. (1996). Pela valorização da engenharia estrutural. ABECE Informa, São Paulo, Entrevista, ano 1, n.7, p.1-4. 